\title{
مدى تدخل القضاء الرسمي في إطار الأحكام الصادرة بالتحكيم في منازعات العقود الإدارية
}

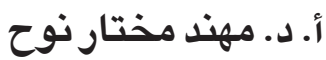 \\ أستاذ القانون العام}

كلية القانون ، جامعة قطر

| الماخص

يناقش هذا البحث مدى تدخل قضاء الدولة في الأحكام التحكيمية الصـادرة في منازعات

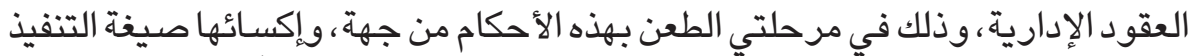

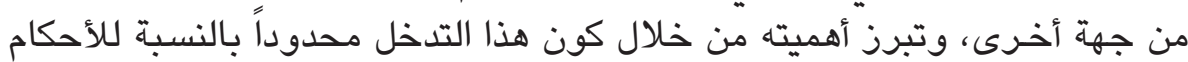

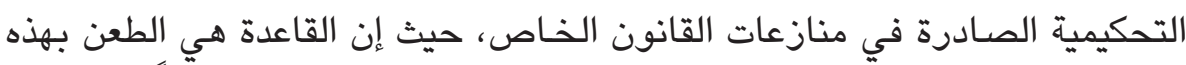

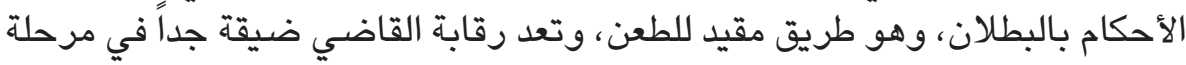

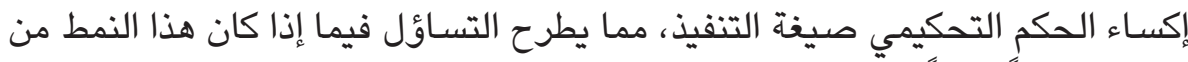

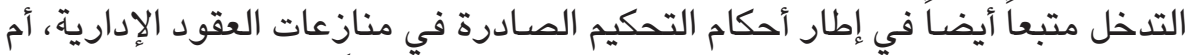

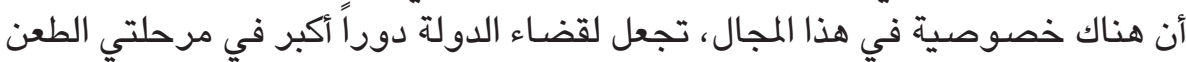

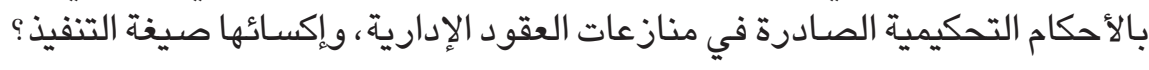
لذلك فإن الدافع إلى اختيار هذا البحث يتمثل في البحث في خصوصية تعامل قضـاء

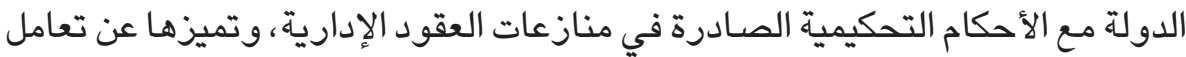

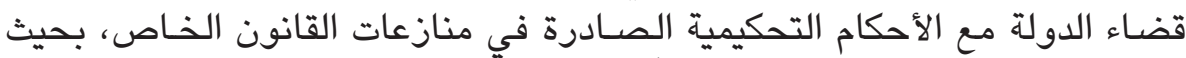

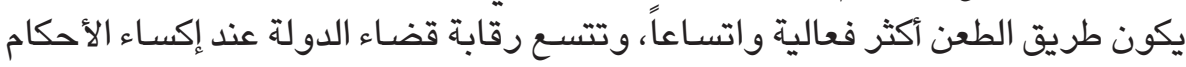

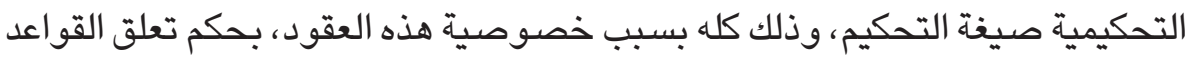
التي تحكمها بالنظام العام، واتصـال محلها بالأموال العامَة.

وسيتم التطرق إلى مفردات البحث من خلال المقارنة مع النظامين القانونيين السائدين

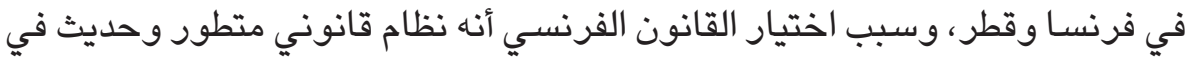

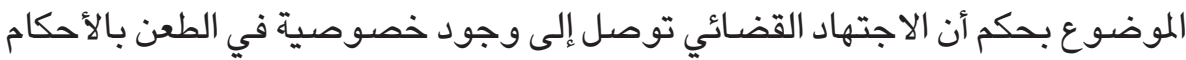

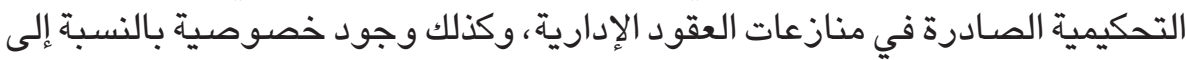

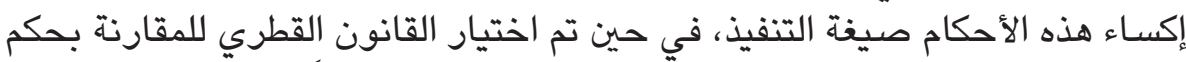

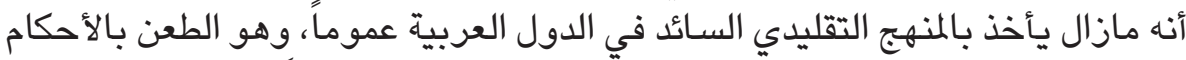

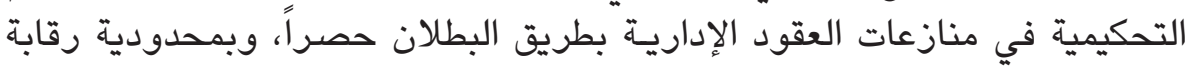




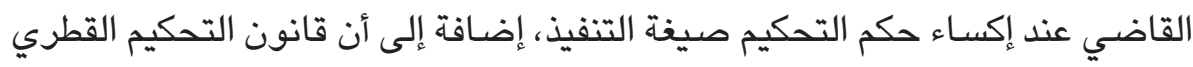

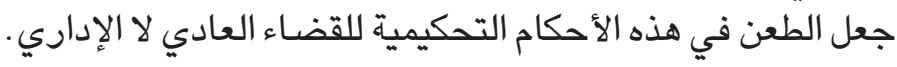

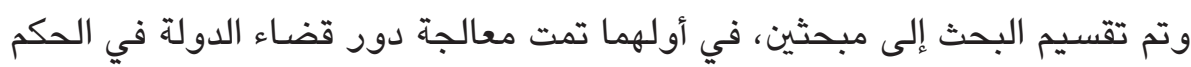

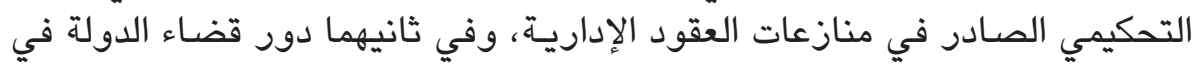

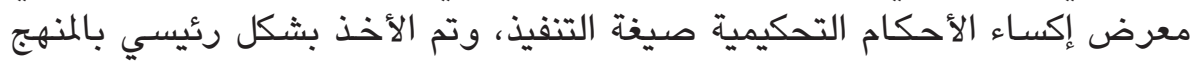
المقارن. - (معرض.

وأهم النتائج التي تم التوصل إليها في البحث تلك المتعلقة باختصاص القضاء الإداري

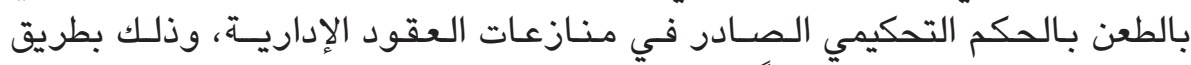

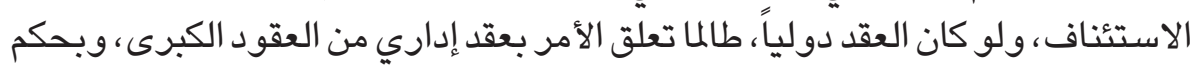

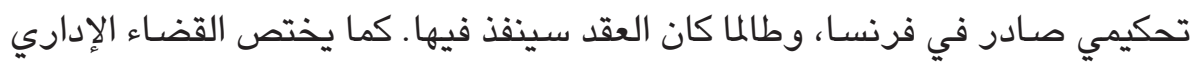

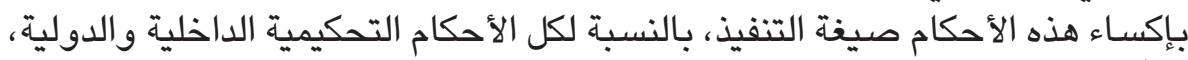

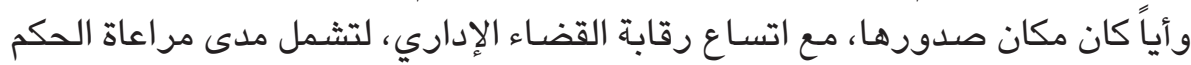

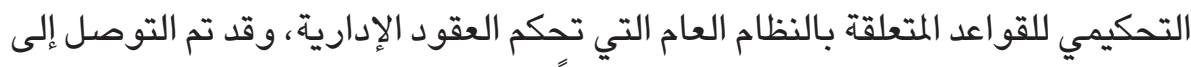

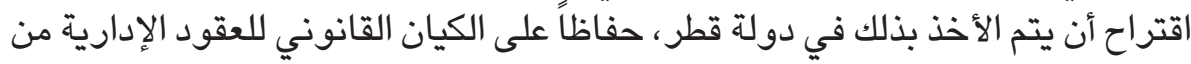

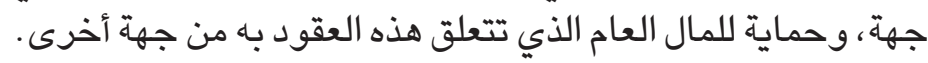

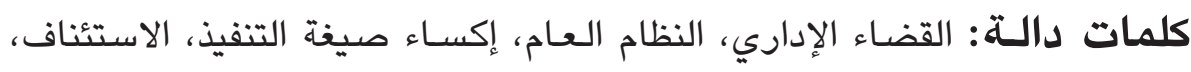
البطلان. 
المقدمة

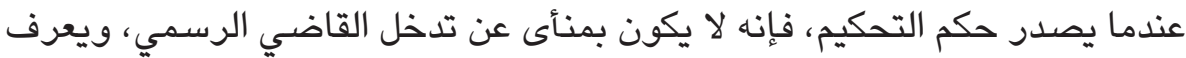

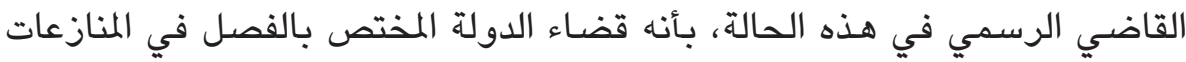
بمقتضى الأحكام القانونية والدستورية السائدة في الدولة.

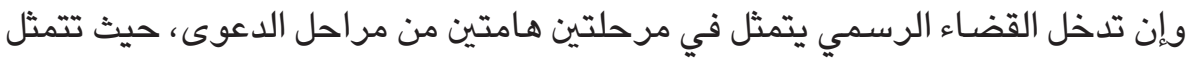

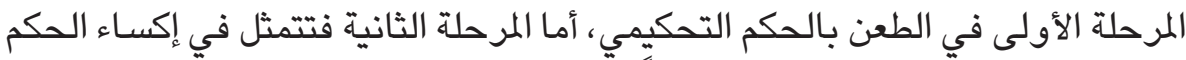

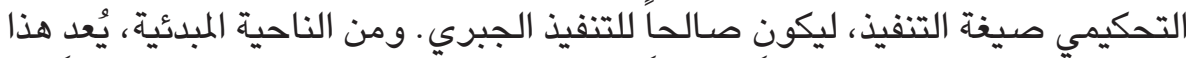

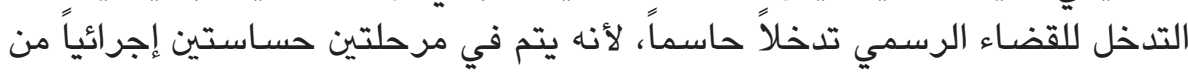
مراحل الدعوى.

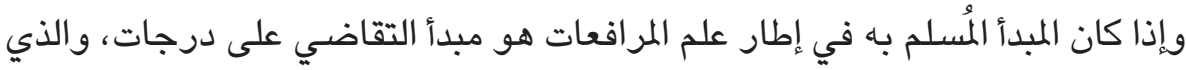

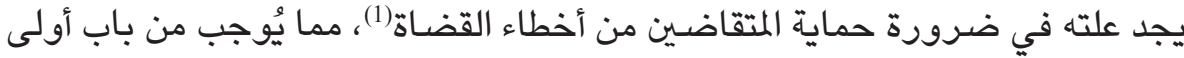

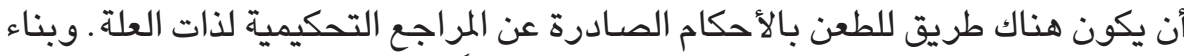

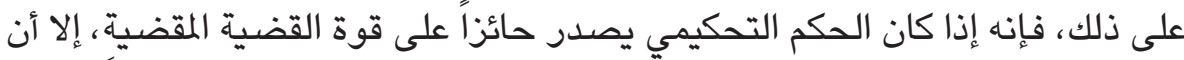

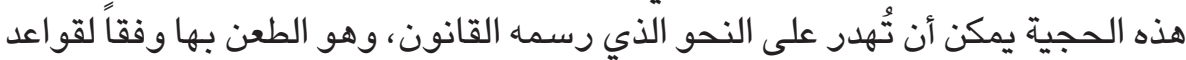
الطعن المقررة (2).

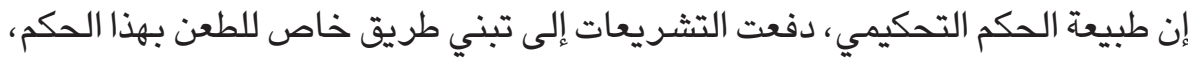

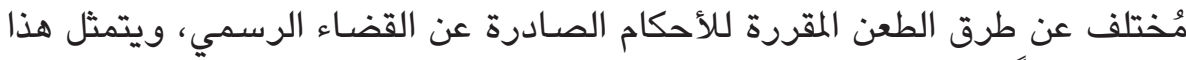

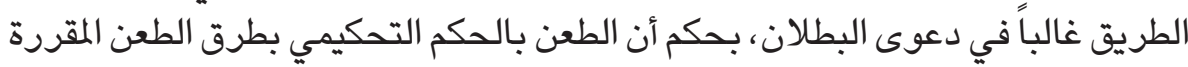

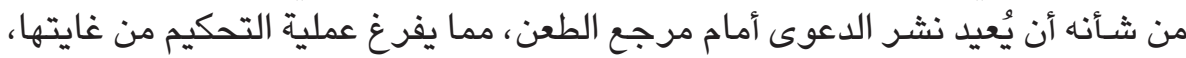

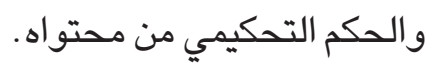

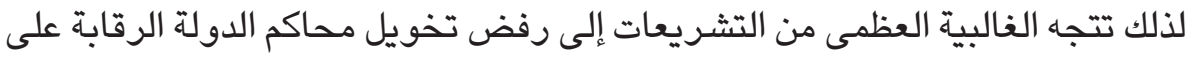
تقدير المحكم لوقائع النزاع، وتتجه هذه التشريعات إلى عدم إجـازة طرق الطئ الطعن التي

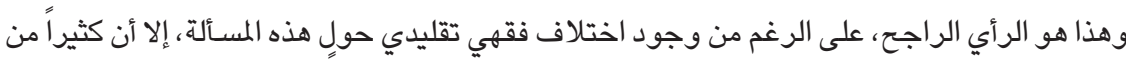

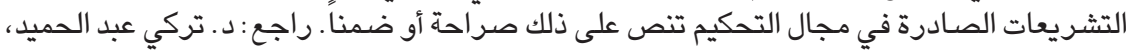

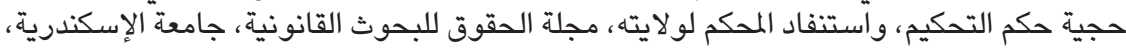

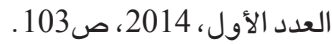
راجع في الغاية من طرق الطعن عموماً: د. أحمد السيد صاول، واوي، الوسيط في شرح قانون المرافعات

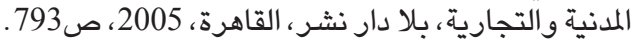




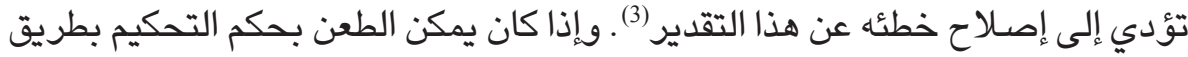

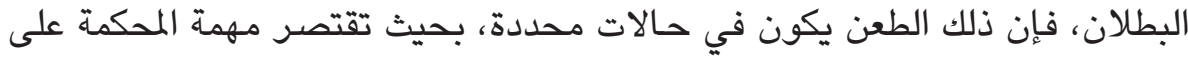

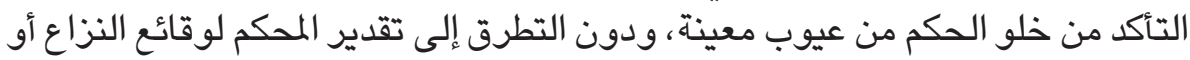

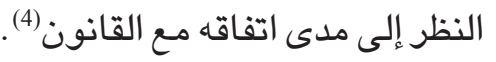

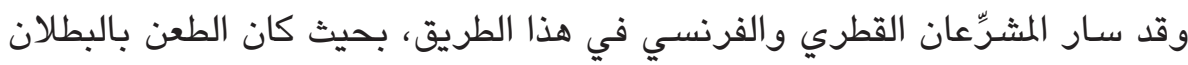

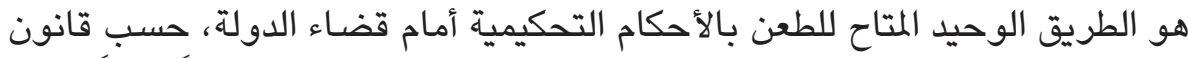

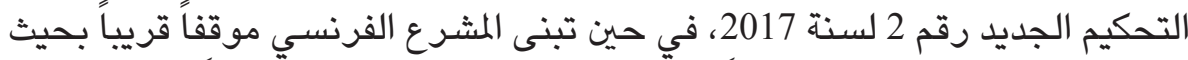

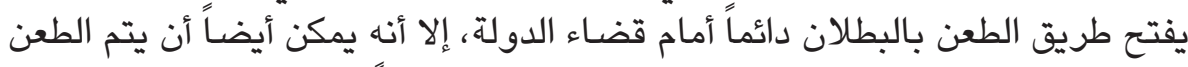

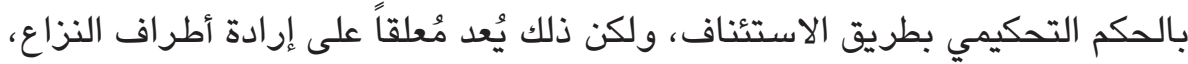

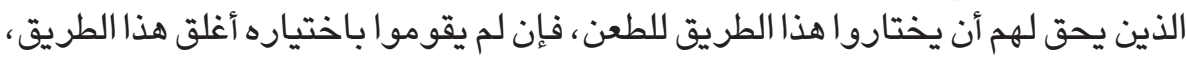
ولا يبقى بعد ذلك إلا طريق الطعن بالبطلان.

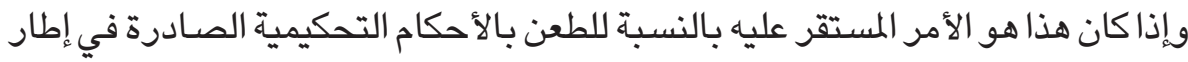

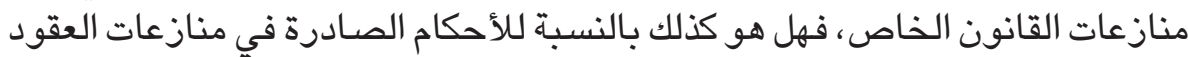

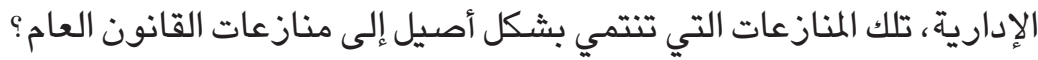

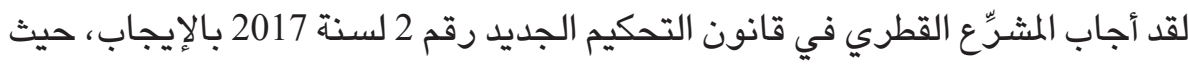

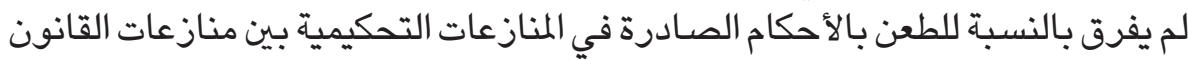

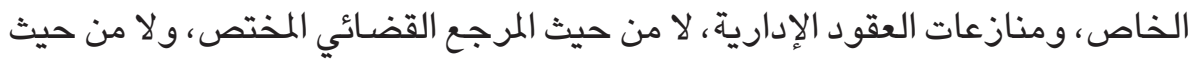

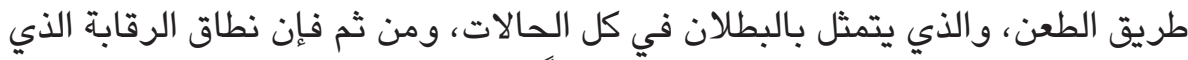

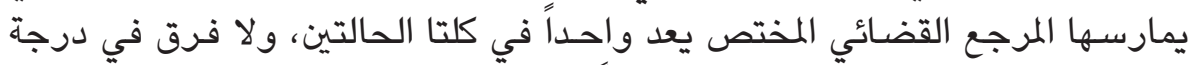

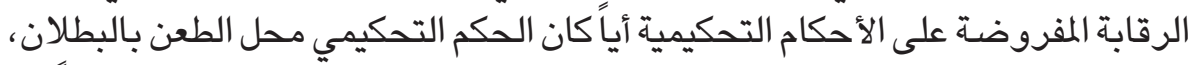

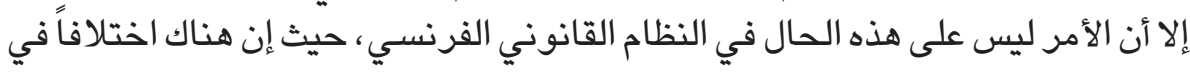

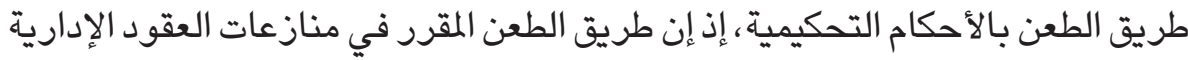

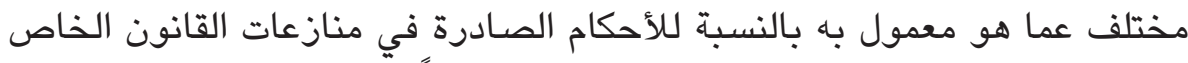

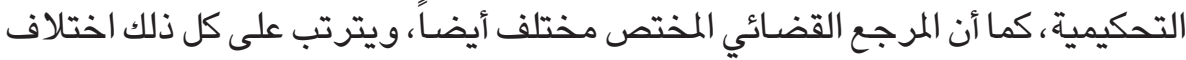
في درجة الرقابة التي تمارس على الحكم التحكيمي في كلتا الحالتين.

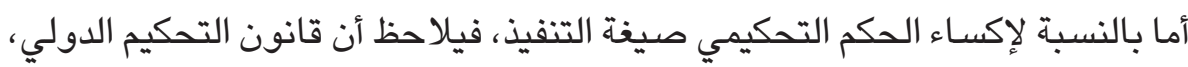

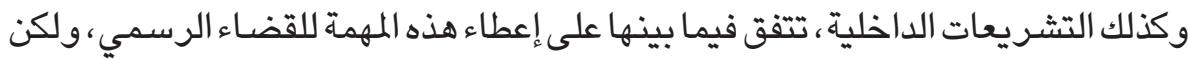
(3) د. علي مصطفى الشيخ، التحكيم على درجتين، مجلة البحوث القانونية والاقتصادية، كلية الحقوق،

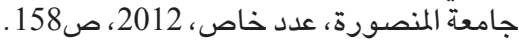

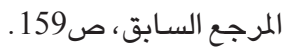


مع تحديد الحالات التي يمكن لهذا القضـاء أن يرفض خلالها إكسـاء صيغة التنفيذ، مـ الحذر الشـديد تجاه تطرق القضـاء الرسمي لموضوع الحكم التحكيمي في هذه المرحلة. وقد سـار قانون التحكيم القطري رقم 2 لسنة 2017 في هذا الاتجاه بالنسبة للأحكام

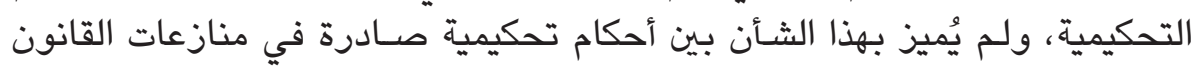
الخـاص، أو تلك الصـادرة في منازعات العقود الإداريسة، على خلاف النظام القانوني

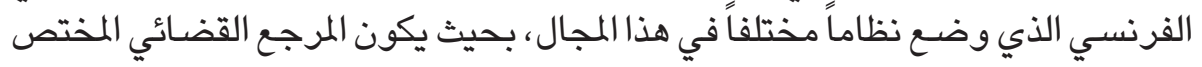

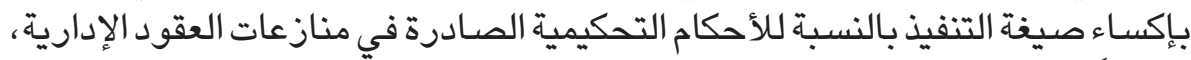

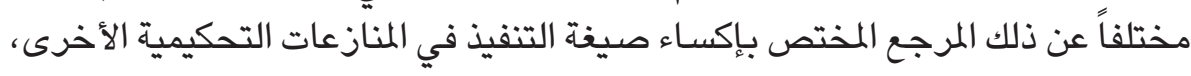
ومع ارتفاع سلطة القاضي الإداري في هذه المرحلة.

ومن هنا تأتي أهمية البحث، فخصوصية النظام القانوني الذي تخضـع له العقود الإدارية،

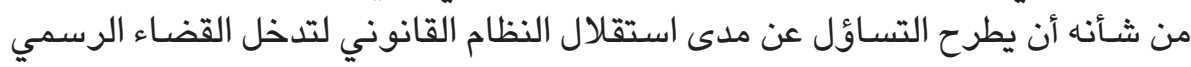
في إطار الأحكام التحكيمية الصـادرة في منازعات هذه العقود عن نظيرتها السـائدة في إطار القانون الخاص، ولاسيما في الدول التي تتبع منهج القضـاء المزدوج مثل فرنسا خصوصاً.

ولعل المشاكل التي أحاطت بإنجاز هذا البحث تمثلت خصوصاً بالحداثة الكلية لمادته، ومشـاكله، فقد صدر قانون التحكيم القطري منذ فترة وجيزة، كما أن النظام القانوني لتدخل القضـاء الرسمي في إطلار الأحكام التحكيمية الصـادرة في منازعات العقود

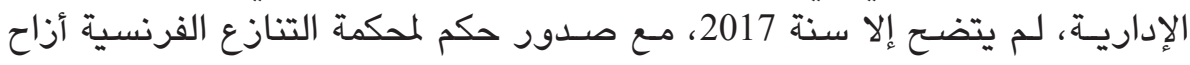
الغموض عن كثير من المشـاكل المتعلقة بإكسـاء الأحكام التحكيمية الصـادرة في منازعات العقود الإدارية لصيغة التنفيذ.

وقد اتبعنا في هذا البحث منهجاً مقارناً، بحيث بحثنا تدخل القضـاء الرسمي في إطار الأحكام التحكيمية الصـادرة في منازعات العقود الإدارية في كل من النظامـين القانونيين السـائدين في قطر وفي فرنسـا. وسوف نتبع في هذا البحث تقسيماً ثنائياً، بحيث نتطرق في المبحث الأول إلى تدخل قضـاء الدولة في إطار الطعن في الحكم التحكيمي الصـادر في منازعات العقود الإدارية ، أما في المبحث الثاني فنتطرق إلى تدخل القضـاء الرسـمي في إطار إكسـاء الأحكام التحكيمية الصـادرة في منازعات العقود الإدارية لصيفة التنفيذ، وذلك على النحو التالي : 


\section{المبحث الأول}

\section{تدخل القضاء الرسمي في إطار الطعن بالحكم التحكيمي الصادر في منازعات العقود الإداريّة}

لقد أقرَّ المشرِّع القطري التحكيم في العقود الإدارية صراحة في قانون التحكيم الجديد

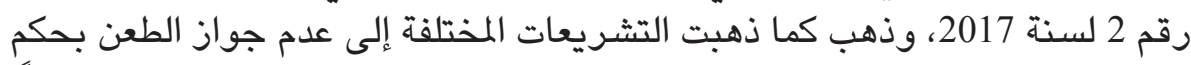

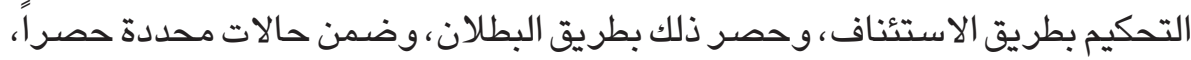

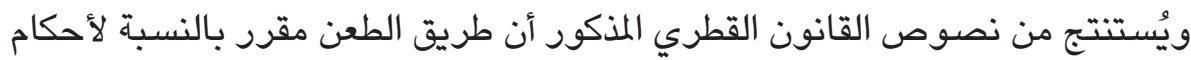

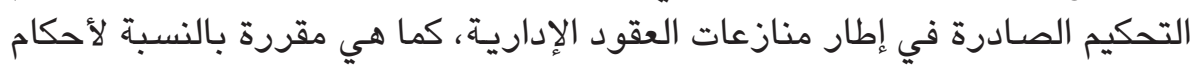

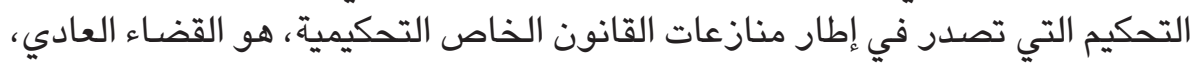

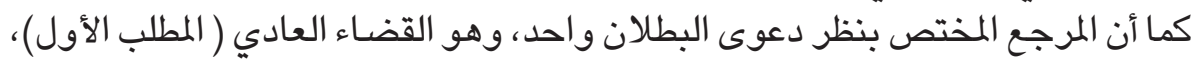

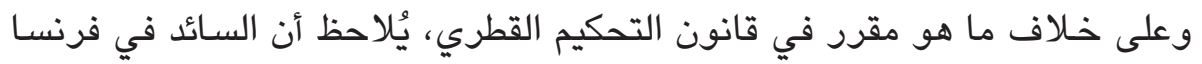

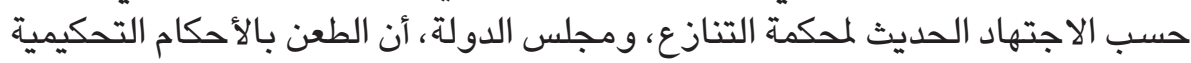

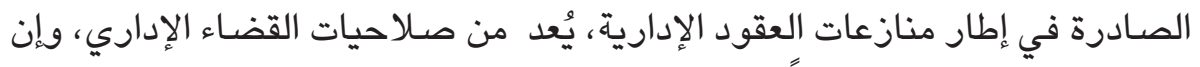

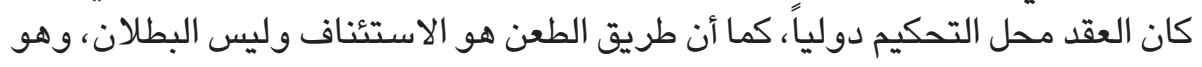

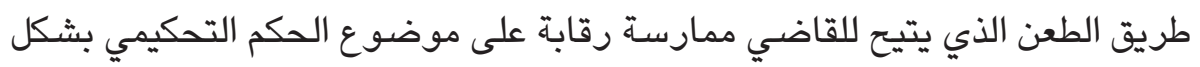
واسع (المطلب الثاني).

\section{المطلب الأول}

الوضع في القانون القطري: اختصاص القضساء العادي بـالطعن بالأحكام التحكيمية الصادرة في منازعات العقود الإداريتّ

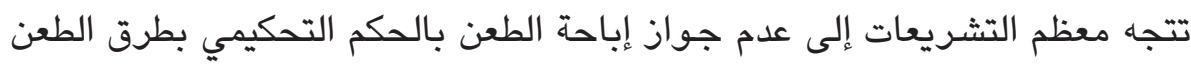

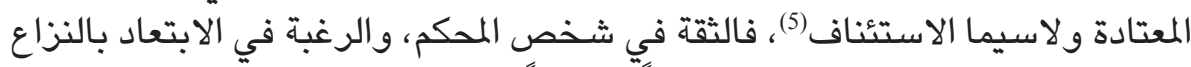

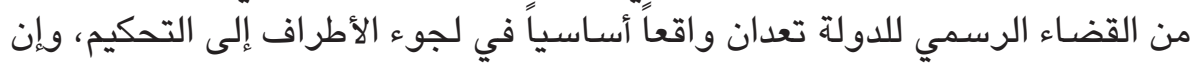

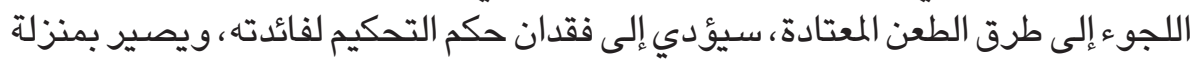

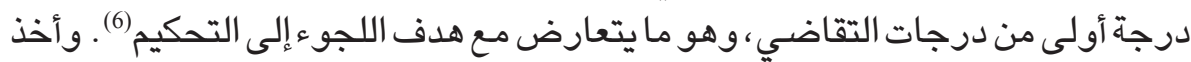

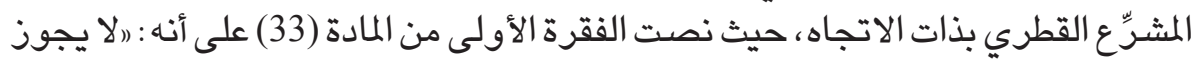

(5) راجع في ذلك مفصلاً: د. فتحي والي، قانون التحكيم في النظرية والتطبيق، منشأة المعارف،

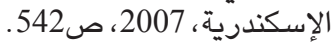

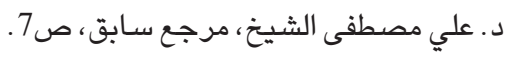




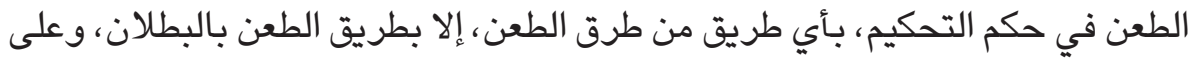

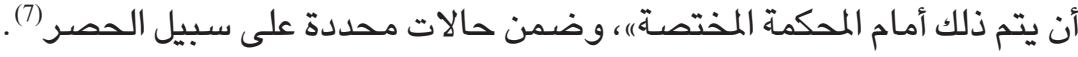

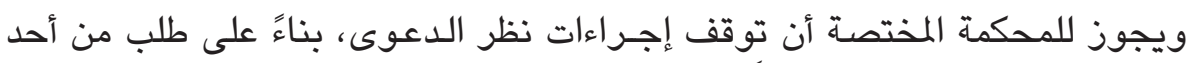

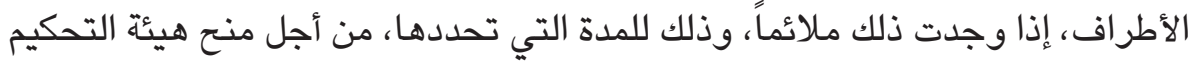

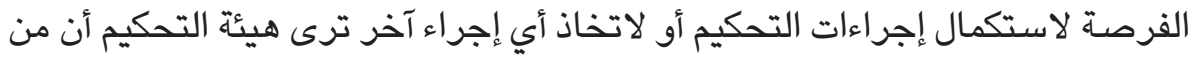

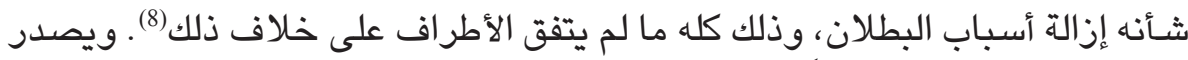

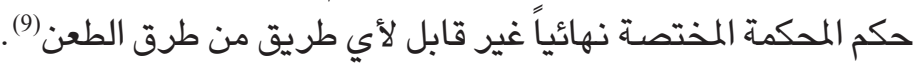

$$
\text { وفقاً لنص المادة (33) من قانون التحكيم رقم } 2 \text { لسنة 2017، فإنه: }
$$

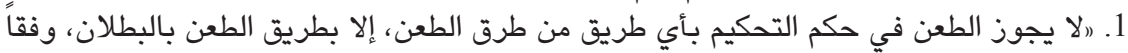

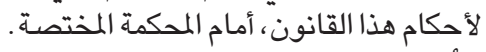

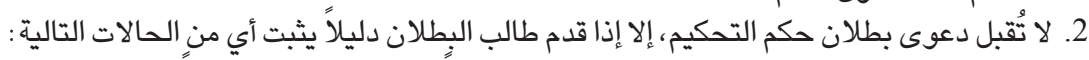

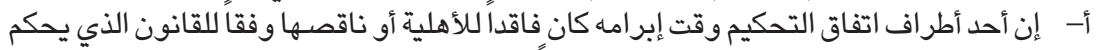

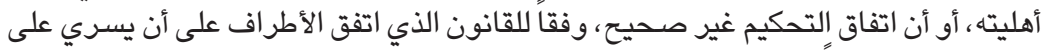

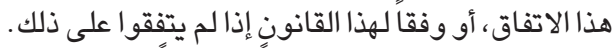
ب- إن طالب الإبطال لم يُعلن إعلاناً صحيحاً بتعيين أحد المحكمين أو بإِ إجراءات التحات التحكيم، أو تعذر

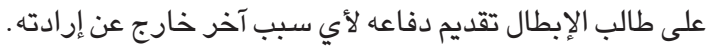

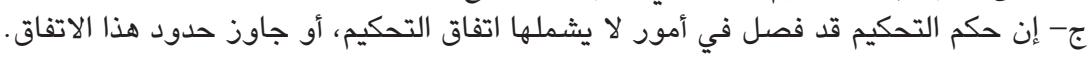

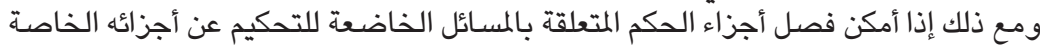
بالمسائل غير الخاضعة له، فلا يقع البطلان إلإ الإ على الأجزاء الأخيرة فقط.

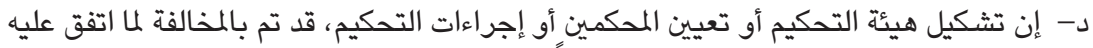

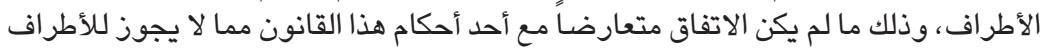

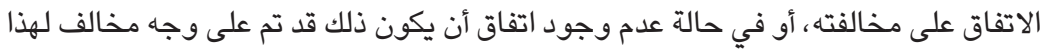

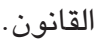

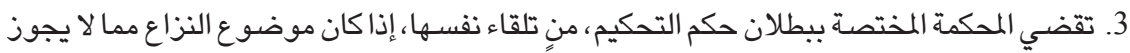

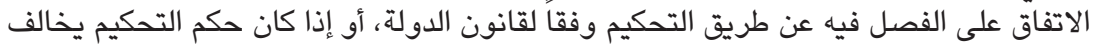

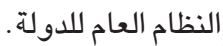

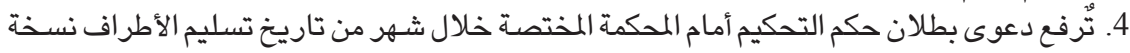

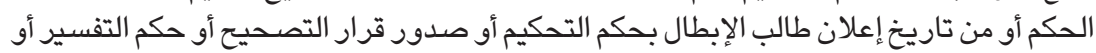

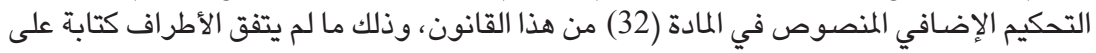

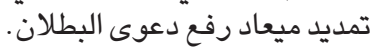

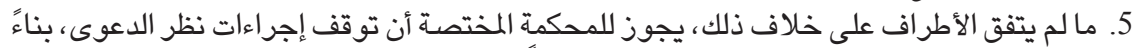

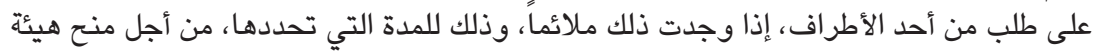

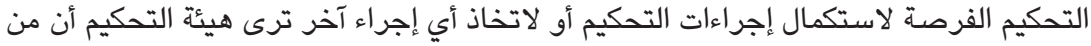

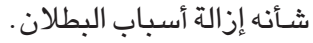
6. يكون حكم المحكمة المختصة نهائياً وغير قابل للطعن عليه بأي طريق من طرق الطعن).

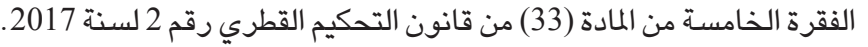
الفقرة السادسة من المادة (33) من قانون التحكيم القطري رقم 2 لسنة 2017. 


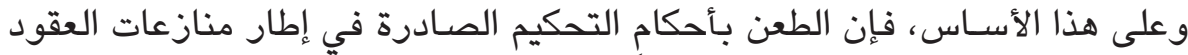

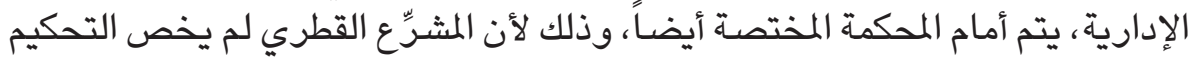

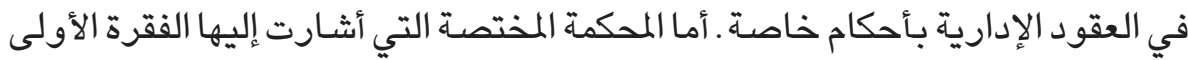

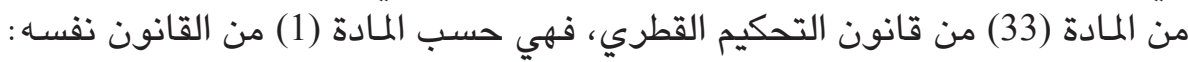

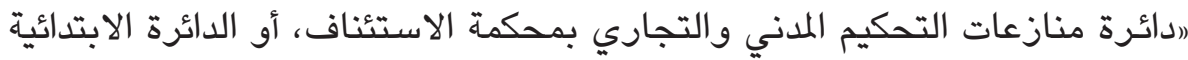

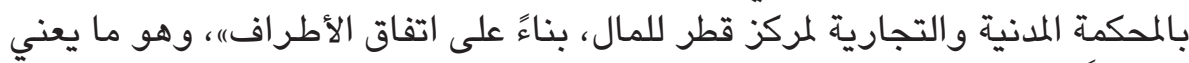

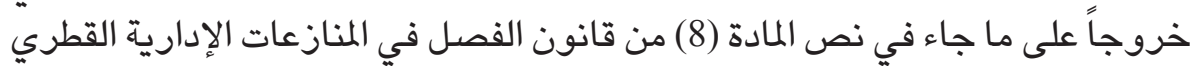

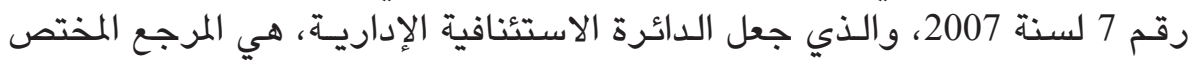

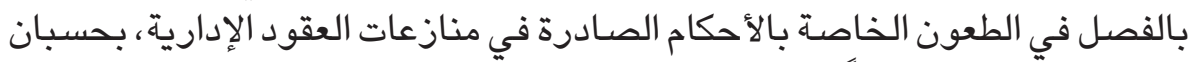

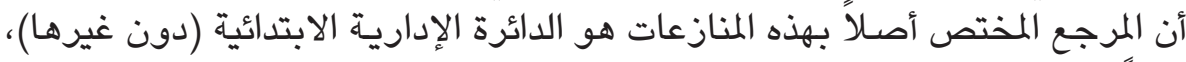

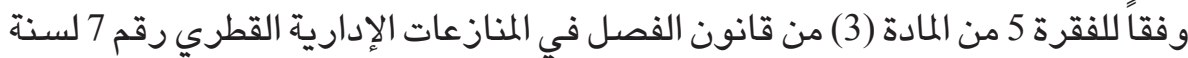

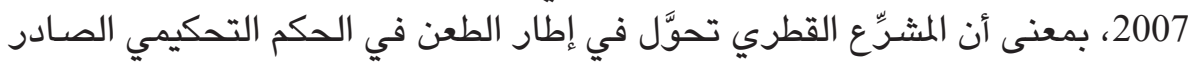

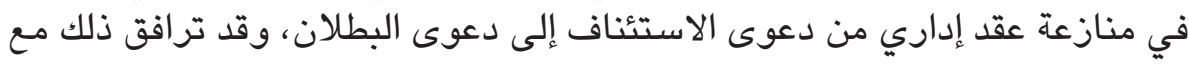

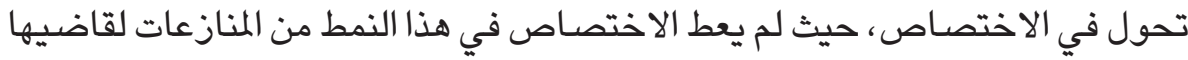

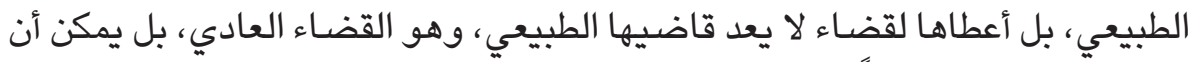

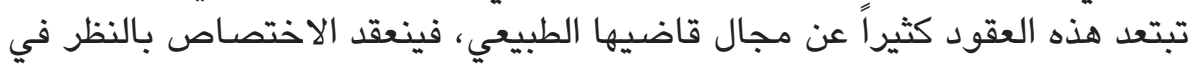

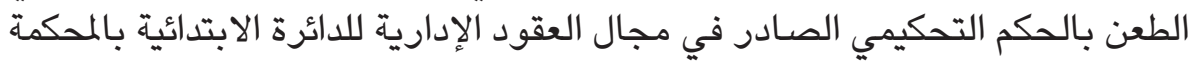
المدنية والتجارية لمركز قطر للمال (10).

وبناءً على ما تقدم، فـإن السؤال الذي يطرح نفسه، هو كيف تتعامل الدائرة المدنية

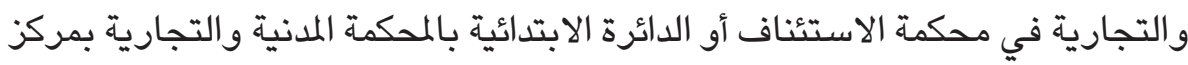

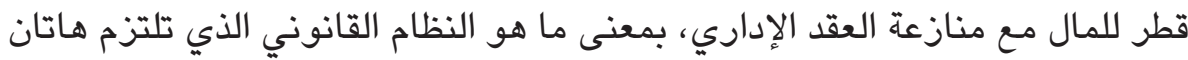

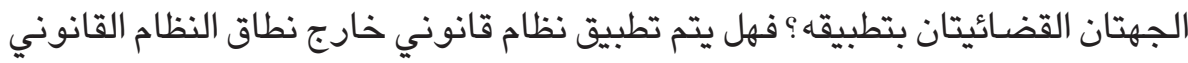

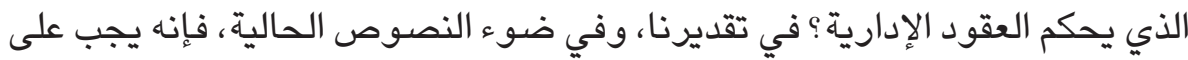

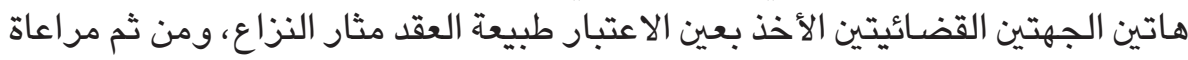

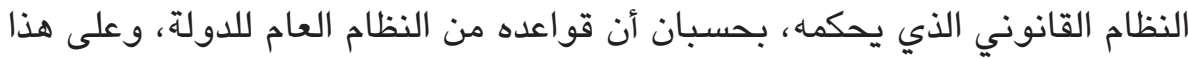

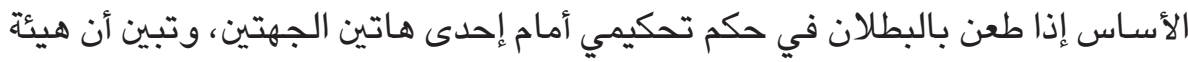

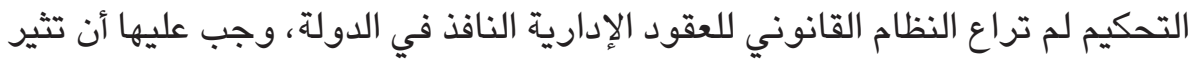

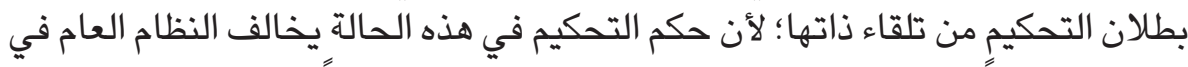

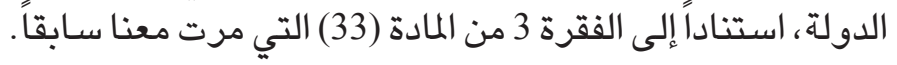

(10) المادة رقم (5) من القانون 2 لسنة 2009 المعدل للقانون رقم 7 لسنة 2005. 


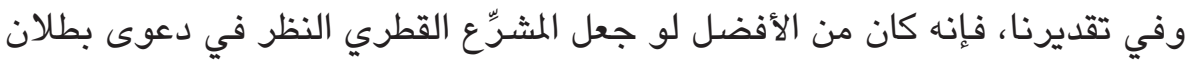

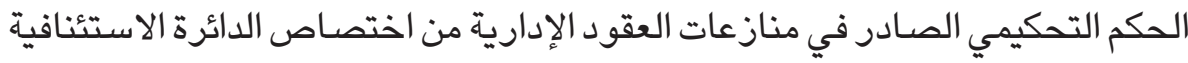

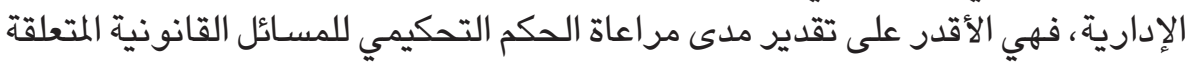

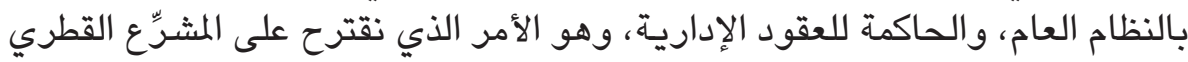

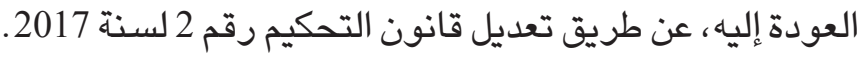

\section{المطلب الثاني \\ الوضع في القانون الفرضسي: اختصاص القضاء الإداري بالطعن

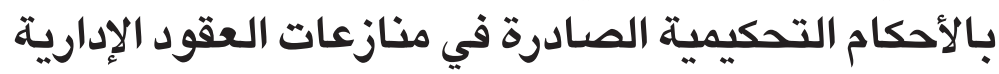

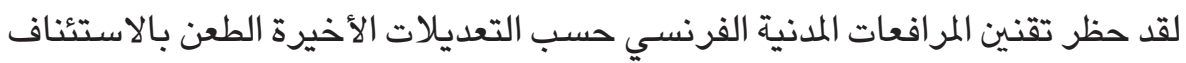

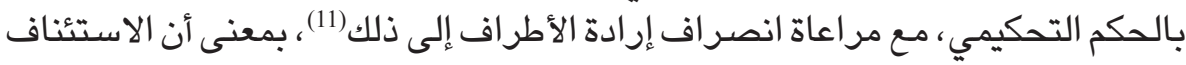

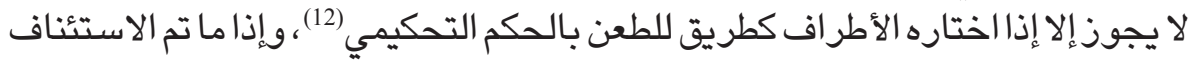

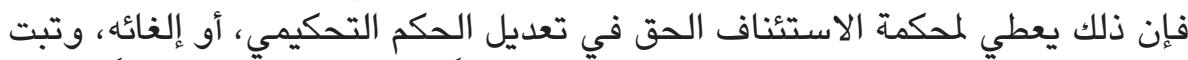

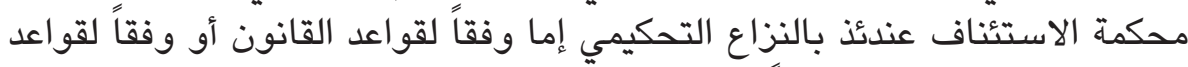

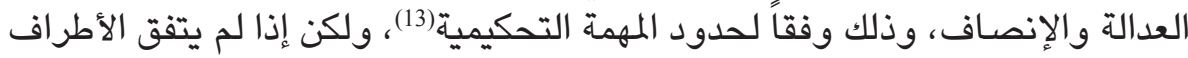

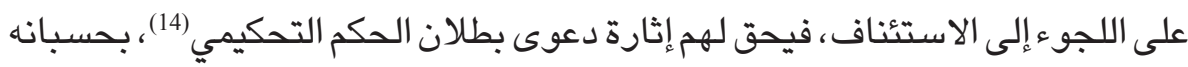

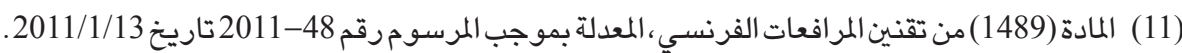

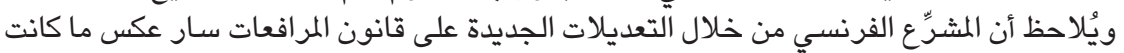

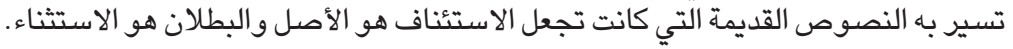

(12) Loquin.E, La réforme du droit français interne et international de l'arbitrage, RTD Com, 2011, p. 240.

(13) المادة (1490) من تقنين المرافعات الفرنسي، المعدلة بموجب المرسوم رقم 48-2011 تاريخ 2011/1/13. وراجع في الفقه:

Loquin. E, La réforme du droit français interne et international de l'arbitrage, op. cit., p. 240.

(14) وقد حددت المادة (1492) من قانون المرافعات الفرنسي المعدلة بموجب المرسوم رقم 48-2011 تاريخ

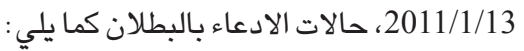

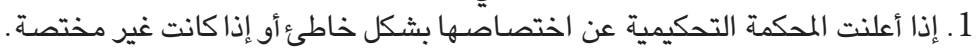

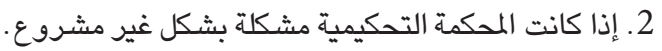

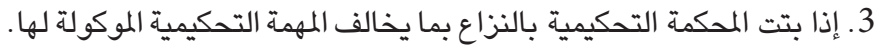

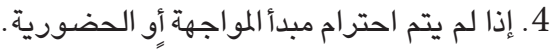

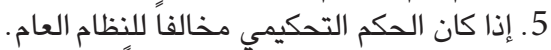

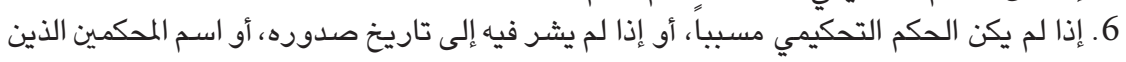
أصدروه، أو إذا لم يصدر بـالأغلبية المطلوبة. 
الطريق المفتوح دائماً للطعن بالحكم التحكيمي، ما لم يتفق الأطراف على اللجوء إلى الاستئناف (15).

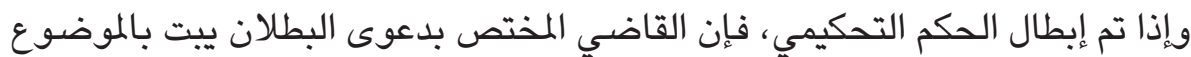

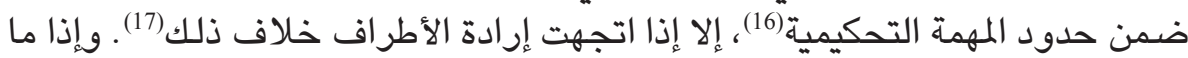

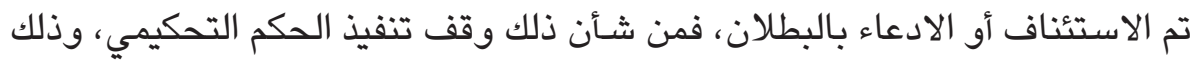

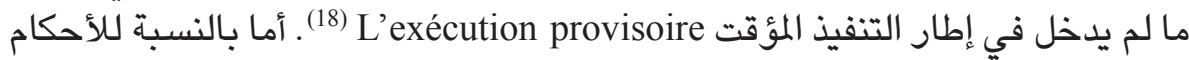
التحكيمية الدولية(19)، فإن البطلان هو التفيذ المؤت الطريق الوحيد الممكن للطعن بالحكم التحكيمي (20)،

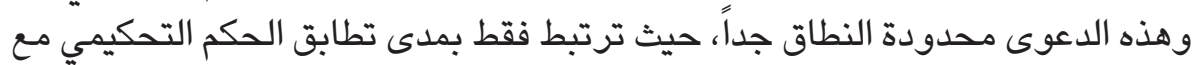

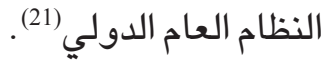

أما في إطار العقود الإدارية فيلاحظ أن الأمر مختلف، حيث تتم التفرقة في إطار المنازعة

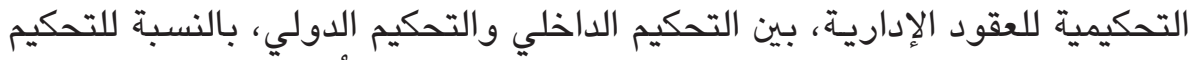

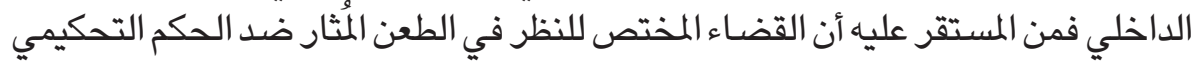

(15) المادة (1491) من تقنين المرافعات الفرنسي، المعدلة بموجب المرسوم رقم 48-2011/13 تاريخ

$.2011 / 1 / 13$

Emmanuel Gaillard, Le nouveau droit français de l'arbitrage interne et international, Études et Commentaires, Chroniques Arbitrage, Recueil Dallaz, 20 Janvier 2011, No: 3, p.175.

(16) وفقا للمادة (1494) من تقنين المرافعات الفرنسي، المعدلة بموجب المرسوم رقم 48-2011/2011 تاريخ

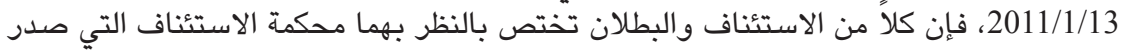

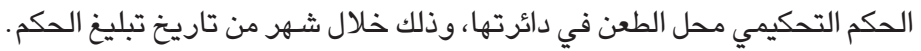

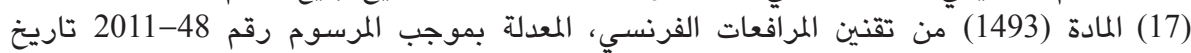
2011/1/13

(18) المادة (1496) من تقنين المرافعات الفرنسي، المعدلة بموجب المرسوم رقم 48-2011/13 تاريخ 2011/1/13 (19) يكون التحكيم دولياً إذا كان متصلاً بمصالح التجارة الدولية، راجع المادة (1503) من تقنين المرافعات

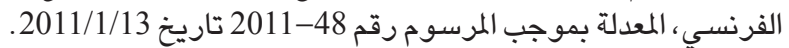

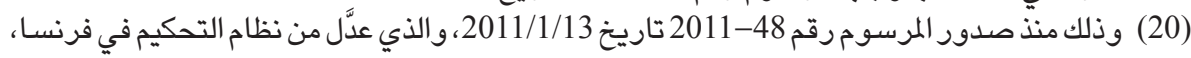

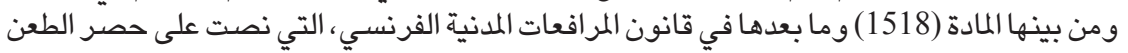

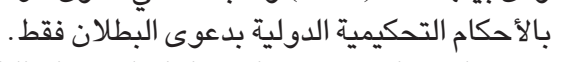

(21) Muscat. H, Les recours devant la juridiction administrative en matière de sentences arbitrales internationales, La Semaine Juridique Administrations et Collectivités territoriales, LexisNexis, Paris, $\mathrm{n}^{\circ}$ (31- 35), 29 Juillet 2013, p. 2245. 
إنما هو ذلك الذي كان مختصـاً أسـاسـاً بالعقد الذي كان محلاً للتحكيم(22). لذلك يمكن القول إن تحديد المرجح المختص بالطعن في الحكم التحكيمي في إطار منازعات العقود الإداريـة هو القضـاء الإداري، ومتى ما توافرت معايير العقد الإداري في العقد مثار النزاع التحكيمي، بحسبان أن هذا القضاء هو المختص بهذا النمط من المناز عات أسـاسـاً (23).

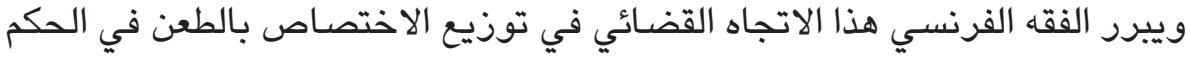
التحكيمي على أسـاس التلازم بين الموضوع والاختصـاص (24)، فيراقب القاضي العادي الحكم التحكيمي المتعلق بنزاع عقد من عقود القانون الخاص للإدارة، في حين ينعقد الاختصـاص للقاضي الإداري بذلك، في حالة كان العقد مثار النزاع إدارياً(25)، إلا أن الأمر فين يختلف بالنسبة للعقود الدولية (المتعلقة بالتجارة الدولية)، حيث يجب التفرقة في هذه الحالة بين عقود القانون الخاص للإدارة، وعقودها الإداريـة، فبالنسبة لعقود القانون

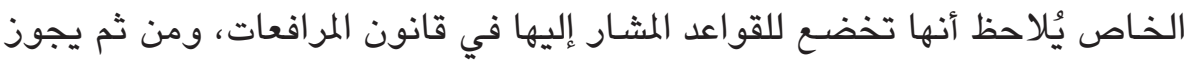
الطعن بالحكم التحكيمي عن طريق الاستئناف، فيإن تنازل الأطراف عنه عند إبرامهم

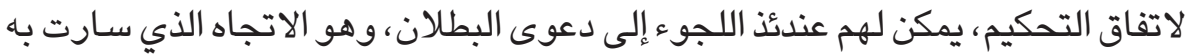

(22) T.C, 16-10-2006, Garsse centrale de réssurance-C-Mutuelle des architectes-Français, n²3506, p. 635, R.F.D.A, 2007, 284, Concl. Sthl.

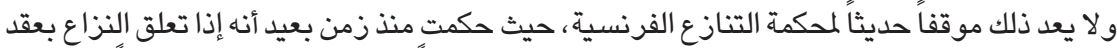

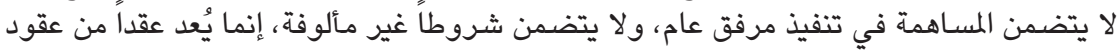

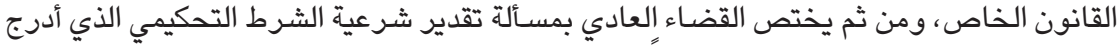

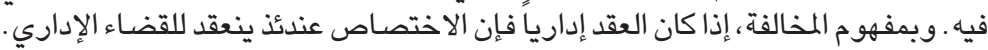

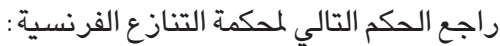

T.C,19-5-1958, Société Mytoon Steamship, R. p.793. D,1958, p.699.

وراجع أيضًا:

Rouault. D, Arbitrage et contrats publics internationaux, Journal de l'arbitrage de l’Université de Versailles, $n^{\circ} 1$, Octobre 2014, 3.

(23) Delvolvé P., Le contentieux des sentences arbitrales national de la recherche médicale, R.F.D.A, Paris, 2010, p. 976. Richer L., Droit des contrats administratifs, L.G.D.J, Paris, 2014, p. 292. Guettier. Ch., Droit des contrats administratifs, P.U.F, Paris, 2011, p. 518. Yolka PH., Traité de droit administratif - Les modes alternatifs de règlement des litiges administratifs, Dalloz, Paris, 2011, T.2, p. 624.

(24) Principe de liaison entre le fonde et la compétence.

(25) Yolka PH., op. cit., p. 624. 
محكمة النقض الفرنسية (26)، واستقرت عليه محكمة التنازع بشكل واضـ(27). إلا أن الإشكال يثور فيما إذا كان العقد إدارياً، ومتعلقاً في الوقت نفسـه بمصـالح التجارة الدولية ، في هذه الحالة ذهب مجلس الدولة الفرنسي ، إلى القول بأن العقد في هذه الحالة

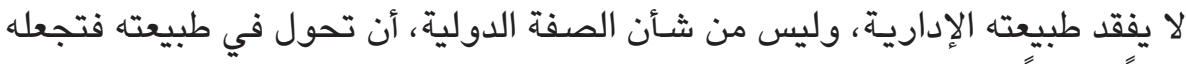
عقدا تجارياً، وأمام الصفتين الإدارية والدولية ، فإن الصفة الإدارية تطفى على الدولية، مما يجعل المنازعة العقدية ضـمن اختصـاص القضـاء الإداري، وبقاء القضـاء الإداري هو المرجع المختص بالطعن في الحكم التحكيمي الصـادر في مثل هذه المنازعات(28). لكن محكمة النقض الفرنسية كان لها اتجاه آخر، حيث طبقت الأحكام الواردة بشـأن

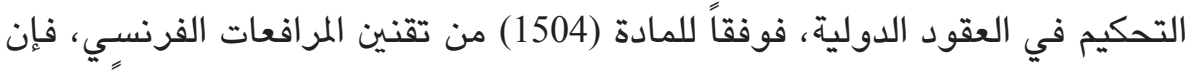

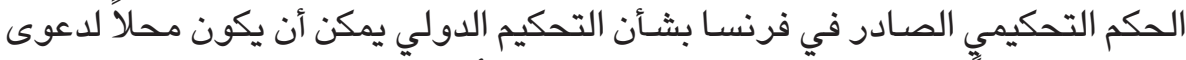
البطلان، ووفقاً للمادة (1505) من التقنين نفسـه، تُرفع دعوى البطلان أمـام محكمة الاستئناف التي صدر الحكم التحكيمي في دائرتها، وعندما طبقت محكمة النقض هذه

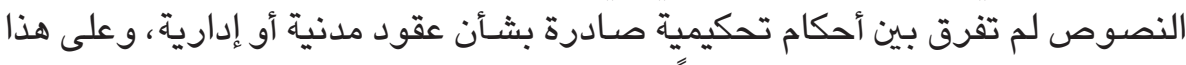

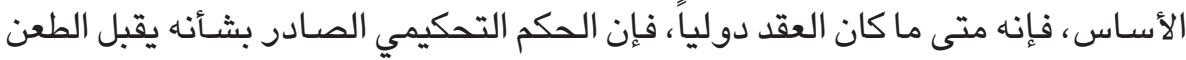
بالبطلان أمام القضـاء العادي، ومن ثم فيان محكمة النقض الفرنسية سـارت في سياسـة مخالفة لماتم الاستقرار عليه بشأن الأحكام التحكيمية الصـادرة في إطار العقود الداخلية، والتي تعتمد على طبيعة العقد محل النزاع، لتحديد المرجع المختص بالطعن في الحكم التحكيمي (29). وقد فسرت محكمة النقض الفرنسية موقفها هذا على أسـاس الاعتراف بالاستقلال الكامل للقانون التحكيمي بالنسبة للقواعد القانونية الوطنية، وبحكم أن

(26) Civ. 14-4-1964, ONSC- C. Caprtaine du San Carb, J.C.P, 1965, II, 14406.

(27) T.C, 19-5-1958, Societé Myrtoon Stea. ship, Leb, p. 793, D, 1958, 699, Note: J. Robert.

(28) C.E, Avis, 6-3-1986, Les grands avis du conseil d'Etat, 13 ed., 2008, Dalloz, p. 160, Comm. D. Labetoulle.

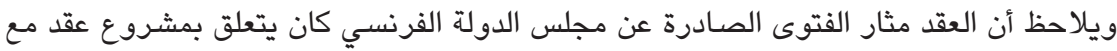

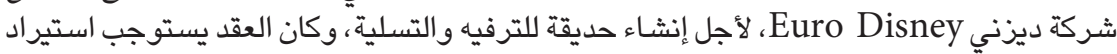

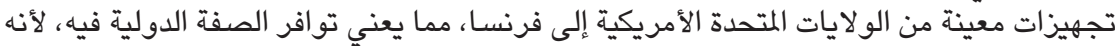

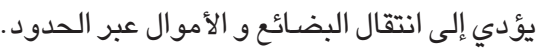

(29) Cass.Civ, 2-5-1966, Rev.crit.D.I.P, 19-è, Note.B.Golden. Cass.Civ.1, 20-12-1993, Bull.CivI, ${ }^{\circ} 372$.

وراجع في الفقه: 518 Guettier.Ch, op.cit, p.

Loquin.E, De la dualité de l'arbitrage commercial et l'arbitrage administratif, R.T.D.C, 2010, p. 525. 
الحكم التحكيمي الذي لا يتصل بـأي نظام قانوني وطني يُعد قراراً للعدالة الدولية(30). وعندما أصدرت محكمة التنازع الفرنسية حكمها في قضية (أنسارم INSERM)، فإنها قد أقرت قاعدة بشـأن المرجع المختص بالطعن بالحكم التحكيمي الصـادر في منازعات

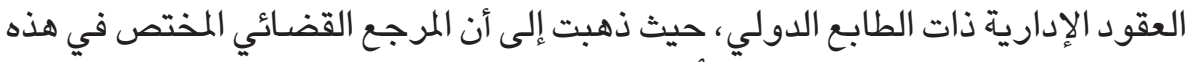
الحالة هو القضـاء العادي، ومن ثم تُرفع الدعوى بيطلان الحكم التحكيمي أمام محكمة الاستئناف المدنية التي صدر الحكم في دائرتها على هدى المادة (1505) من تقنين المرافعات الفرنسي، وذلك ولو كان الحكم متعلقاً بعقد إداري أبرم في فرنسـا وينفذ فيها(31). وقد برر المفوض قويمارGoyomar هذا الاتجـاه في تقريره المقدم لمحكمة التنازع في قضية (أنسـارم INSERM) ذاتها على أسـاس أن مصسالح التجارة الدولية تعطي لكل عقد ولكل تحكيم خصوصيةة، وإن هذه الخصوصية هي التي تسبب اختصـاص القضـاء العادي بالطعن في الأحكام التحكيمية(32). ولعل هذا المبدأ الذي توصلت إليه إليه محكمة

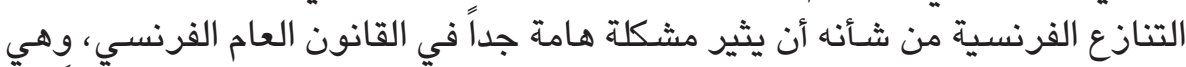
المتعلقة بتجاوز مبدأ الفصل بين السلطات الإداريـة والقضـائية، والمقرر تاريخياً في فرنسا بموجب أحكام المادتين (10) و(13) من قانون 16 و24 أغسطس ولإنس 1790 ومرسوم 16 فركتيدور للسنة الثالثة للثورة (33).

في الواقع، إن الإجابة لابد أن تكون بالنفي، لأن المجلس الدستوري الفرنسي قرر منذ

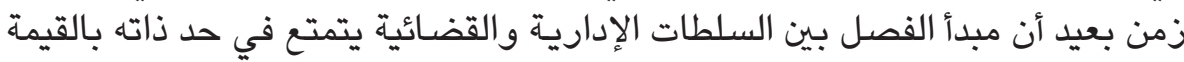
الدستورية، إلا أنه وفقا للمفهوم الفرنسي لمبدأ الفصل بين السلطات، فإن هذا المبدأ يُعد من قبيل المبادئ الأسـاسية المعترف بها من قوانين الجمهورية، وهو ما يترتب عليه

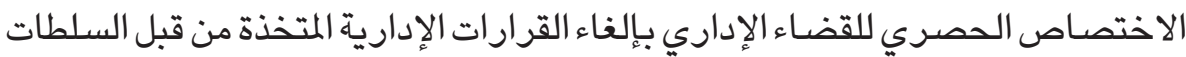
الإدارية ، ضـمن ممارسـة امتيازات السلطة العامة فقط (34).

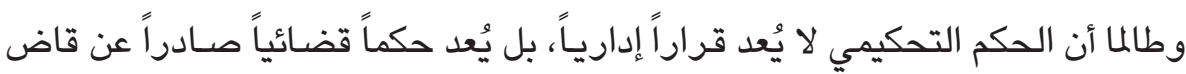
غير رسمي، فإن اختصاص القضـاء العادي بالحكم التحكيمي الصـادر في منازعة عقد

(30) Cass.civ.1, 20-6-2007, Putrabali, Bull, civ, n²50, D, 2007, 1969, obs, Deldech.X.

(31) T. C., 17-5-2010, n ${ }^{\circ}$ C. 3754, Institut national de la santé et de la recherche c. Fondation Letten F. Sausgstad, Rec., p. 580, AJDA 2010. p.1047.

(32) Goyomar M, op. cit., p. 965.

(33) Benoit F. P., Le droit administratif français, Dalloz, Paris, 1968, p.280.

(34) C.C. 23-1-1987, Décision n 86-225, Journal officiel, 25-1-1987, p.925. 
إداري لا يعد محل إشكال دستوري(35). كما أن مبدأ الفصل يُعد ذا قيمة تشـريعية وليس دستورية بموجب اجتهاد مجلس الدولة الفرنسي (36) واجتهاد محكمة التنازع(37). وبناءً على ذلك، فإنه يمكن أن يعدل توزيع الاختصـاصـات بين القضـاء العادي والقضـاء الإداري عن طريق القانون، ولا يحتاج ذلك إلى تعديل دستوري، ومن ثم فإن مشكلة

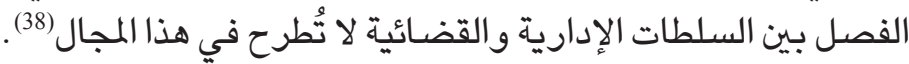
ولكن على الرغم من أن محكمة التنازع قررت اختصـاص القضـاء العادي في كل الأحكام

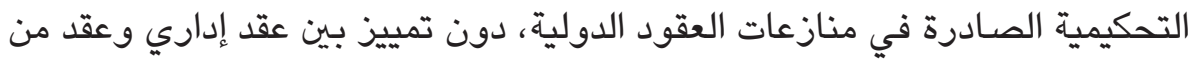

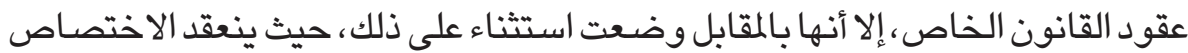

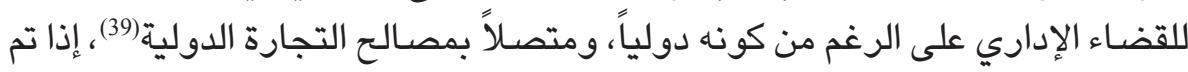
تكييفه على أنه من قبيل العقود الإداريـة بموجب المعايير المعروفة في القانون الداخلي الفرنسي (40)، طالما صدر الحكم محل الطعن في فرنسـا، وكان تنفيذ العقد في الإقليم الفرنسي، وذلك في إطار العقود الإدارية التي يعد نظامها القانوني ذا طابع آمر ومن النظام

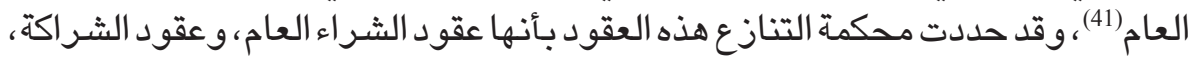

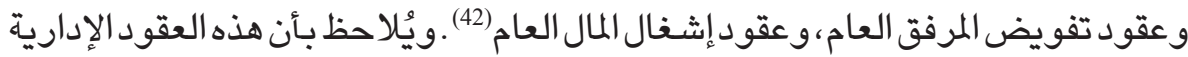

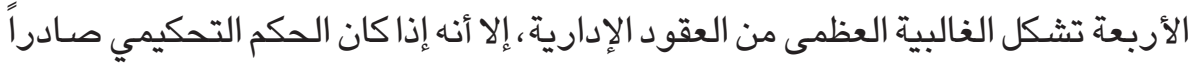
من هيئة خارج فرنسـا، فإن القضـاء الإداري الفرنسي يكون غير مختص بالنسبة للطعن

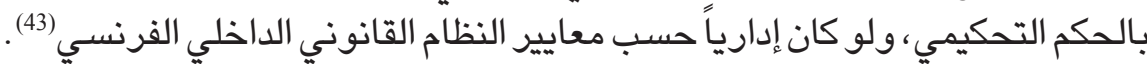

(35) Delvolvé P., op. cit., p. 976.

(36) C.E, 30-5-1962, Association national de la meunerie, leb, 233, D, 1962, A.J.D.A, Paris, 1962, p. 585.

(37) T.C, 2-3-1970, Société Duvoir, SNCF, Leb, p. 885.

(38) Delvolvé P., op. cit., p. 975.

(39) Lombard. F., Arbitrage et droit administratif, R.T.D.C, 2017, p. 54. Lumaire.S, op. cit., p. 2236.

(40) Muscat H., op. cit., p. 2245.

(41) Muscat H., Ibid, p. 2245.

(42) T.C.17-7-2010, INSERM - C- Fondation Latten, Précité.

(43) C.E, 19-4-2013, Syndicat mixte des aéroporté de Charent, A.J.D.A, 2015, p. 822.

وراجع في الفقه: Loquin.E L'exequatur de la sentence international ayant pour objet un litige portant sur un contrat administratif international est de la compétence du juge judiciaire, Impossible accord entre la cour de cassation et le conseil d'Etat, R.T.D.C, Paris, 2016, p. 71. 
وعلى هذا الأسـاس، ينعقد اختصـاص القضـاء الإداري في الطعن بالأحكام التحكيمية

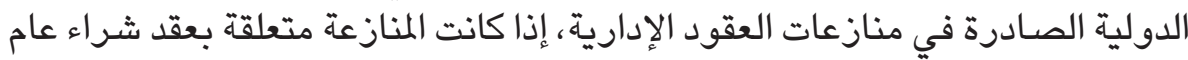
أو عقد شـراكة أو عقد تفويض مرفق عام أو عقد إشـغال مال عام (44)؛ لأن النظام القانوني لهذه العقود يتعلق بالنظام العام، وهناك قواعد آمرة واجبة التطبيق في هذا المجال (45)، لذلك يمكن القول إن النظام القانوني الآمر لهذه العقود الإدارية واجب التطبيق من قبل فيل

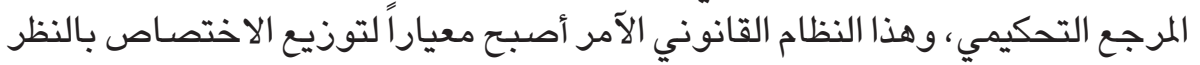
بطعون الأحكام التحكيمية الصـادرة في منازعات العقود الإدارية بين جهتي القضاء (46)، وهو ما يثبت أن الطبيعة الدولية للنزاع التحكيمي لا يمكن أن تمنع من تطبيق قواعد النظام

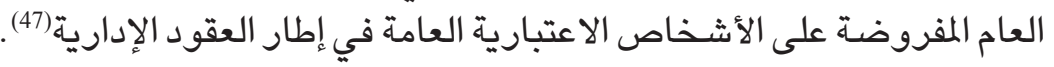
لذلك فقد توصل جانب من الفقه الفرنسي إلى أن ما توصلت إليه محكمة التنازع في

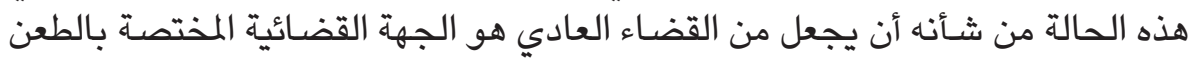

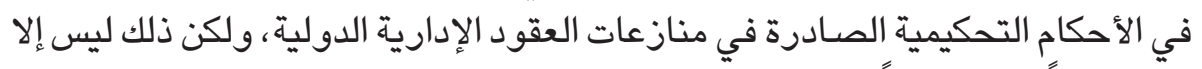

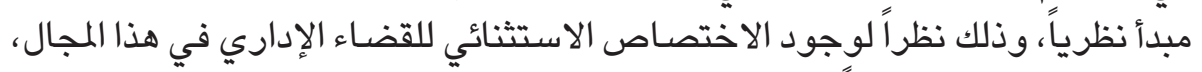
والذي يعد استثناء واسعاً؛ لذلك يمكن القول إن القاضي الإداري أصبح القاضي الجديد بالنسبة للطعن بالأحكام التحكيمية الدولية الصـادرة في منازعات العقود الإدارية في

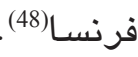

وقد برر جانب من الفقه الفرنسي هذا التوجه لمحكمة التنازع الفرنسية، بأن هذه المحكمة

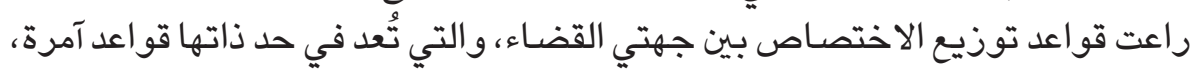

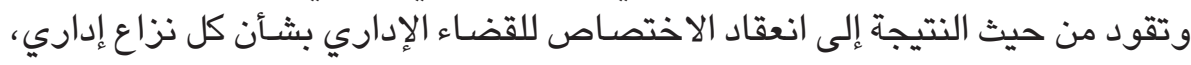
سواء بشكل مباشـر أم بشكل غير مباشـر بالتبعية للتحكيم.

فعلى الرغم من كون العقد الإداري متصلاً بمصسالح التجارة الدولية، إلا أن محكمة التنازع حافظت من خلال هذا الاستثناء الواسـع على منهج التمييز بين العقود الإدارية وعقود القانون الخاص، من خلال القواعد القانونية واجبة التطبيق من جهة، ومن خلال المرجح القضائي المختص بالنظر في الحكم التحكيمي من جهة أخرى (49). فـإذا كان الأمر

(44) Lumaire S., Arbitrage international et droit public, le Tribunal des conflits déçoit, D, 2010, p. 2234.

(45) Lumaire S., Ibid, p. 2230.

(46) Lumaire S., Ibid, p. 2235.

(47) Muscat H., op. cit., p. 2245.

(48) Rouault D., op. cit., n³.

(49) Delvolvé P., op. cit., p. 975. Richer L., Droit des contrats, op. cit., p. 293. 


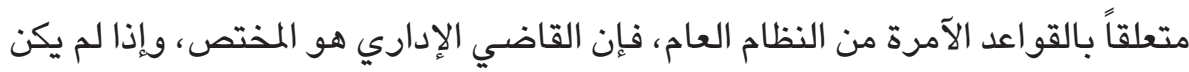

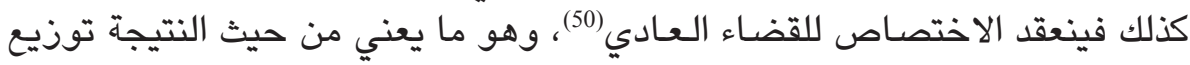

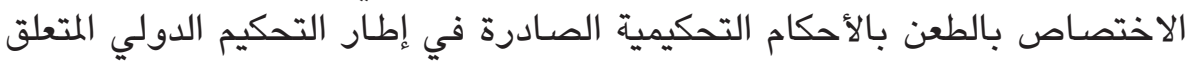

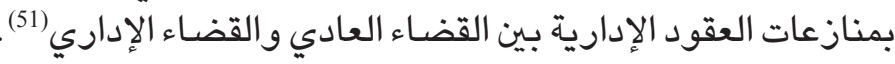

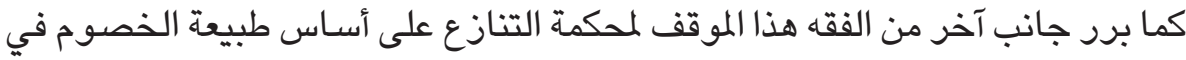

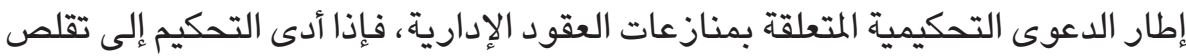

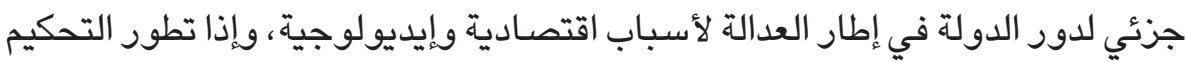

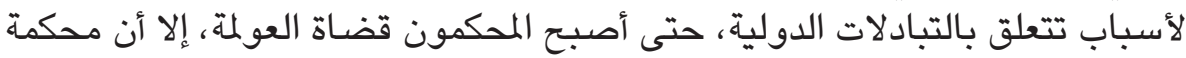

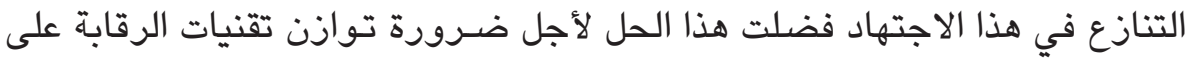

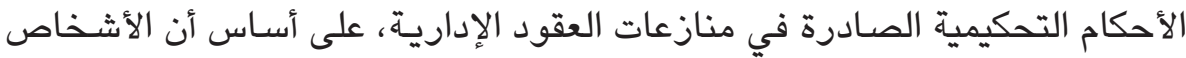

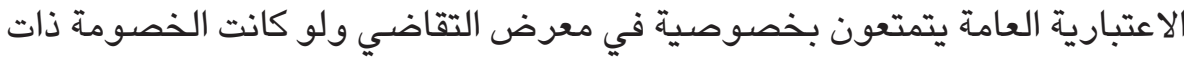
طابع تحكيمي (52).

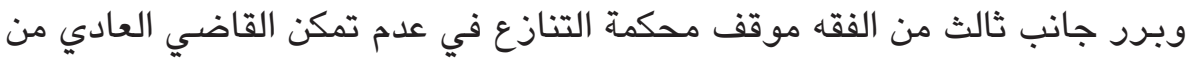

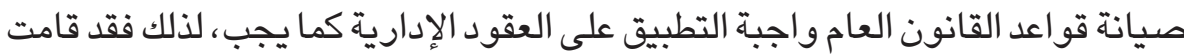

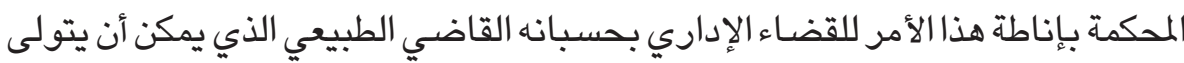
حراسـة قواعد القانون العام (53).

ولكن ماهي قواعد النظام العام المتعلقة بالأنواع الكبرى للعقود الإدارية التي طرحتها

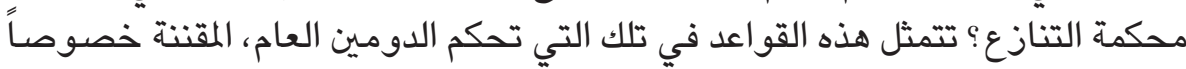

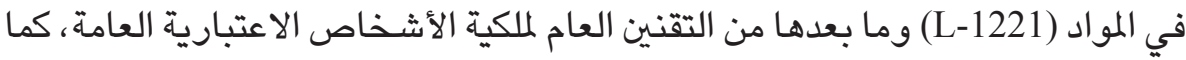

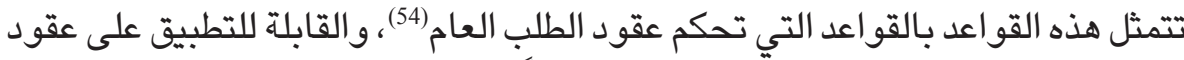

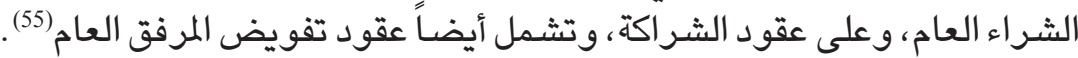

(50) Lumaire S., op. cit., p. 2235.

(51) Loquin E., op. cit., p. 525.

(52) Yolka PH., Traité de droit administratif, op. cit., p. 627.

(53) Lumaire S., op. cit., p. 2235.

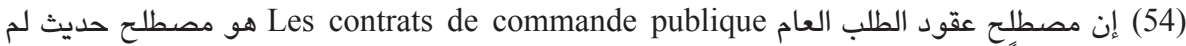

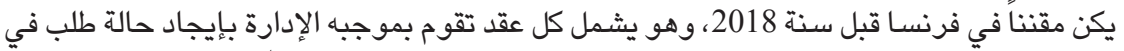

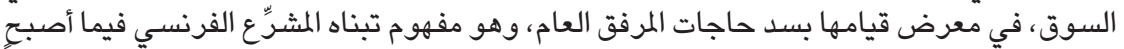

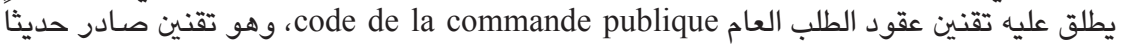

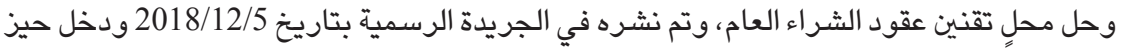

(55) Rouault D., op. cit., $n^{\circ} 3$. النفاذ بدءاً من 2019/4/1. 
بيد أن هذا الاختصاص بالطعن بالأحكام التحكيمية الصادرة في منازعات العقود الإدارية

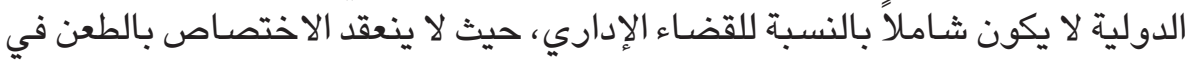

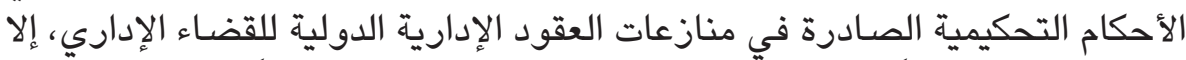

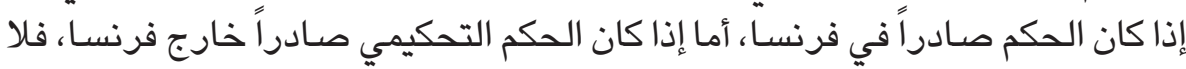

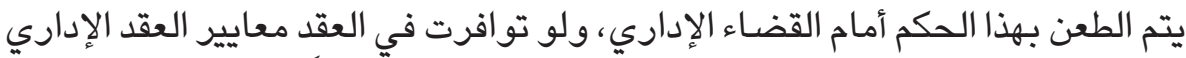

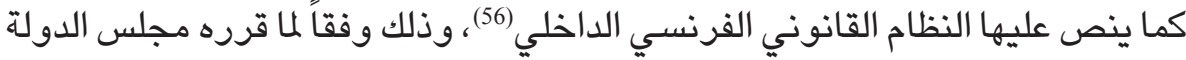
الفرنسي (57)

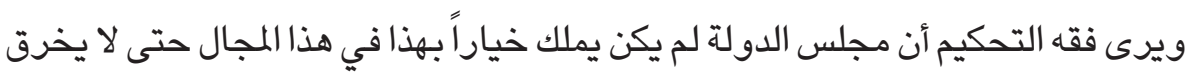

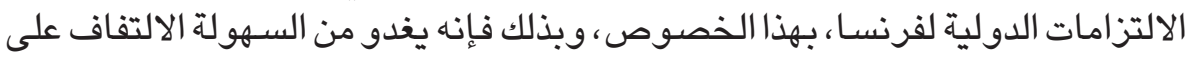

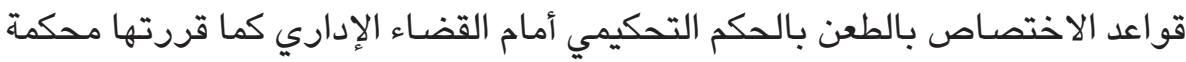

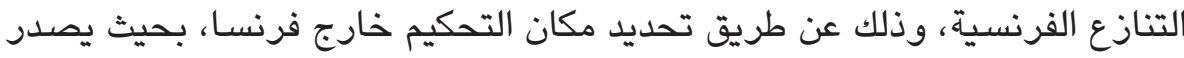

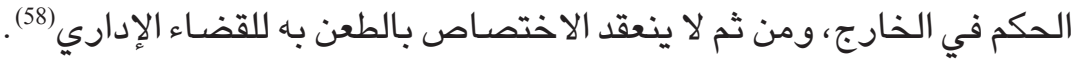

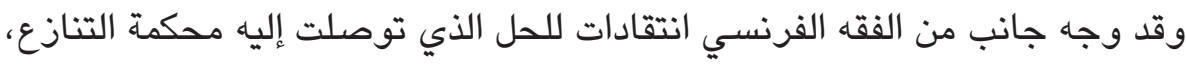

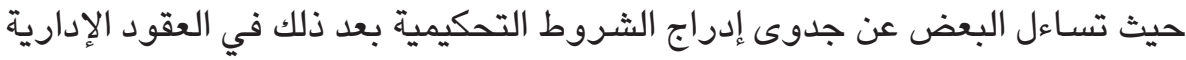

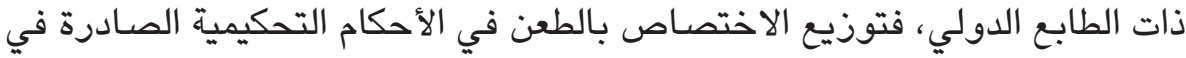

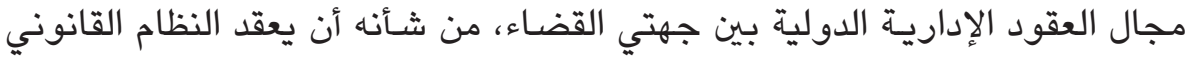

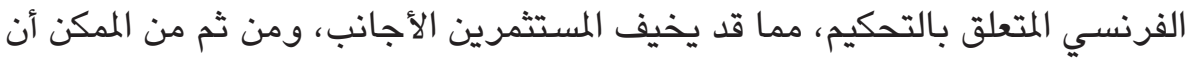

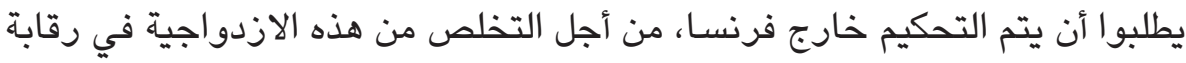

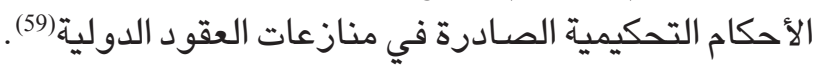

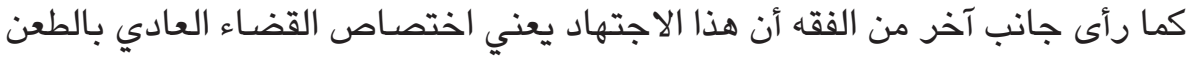

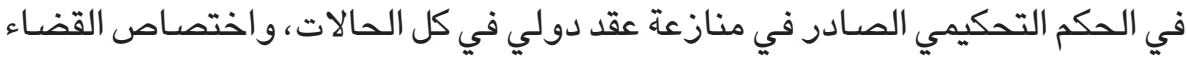

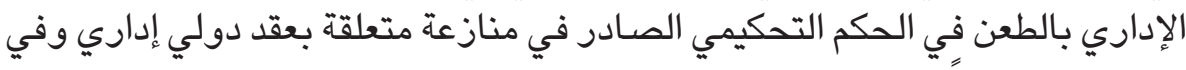

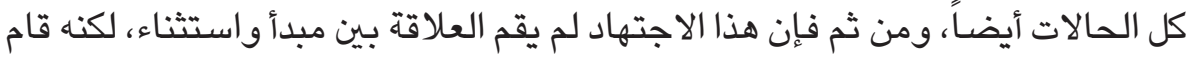

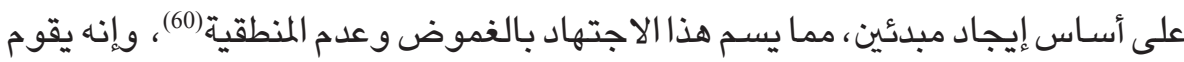

(56) Loquin E, op. cit., p. 71.

(57) C.E, 19-4-2013, Syndicat mixte des aéroporté de Charent, précité. C.E, 5-7-2013, Région Alsace, R. p. 499, A.J.D.A, Paris, 2013, p. 1417.

(58) Rouault D., op. cit., $\mathrm{n}^{\circ} 3$.

(59) Rouault D, op. cit., n³.

(60) Delvolvé P., op. cit., p. 975.ets. 
على معيار غير كاف وغير محدد(61). وبالمقابل فقد رأى البعض الآخر أن هذا الحل الذي اتبعته محكمة التنازع الفرنسية ، أدى

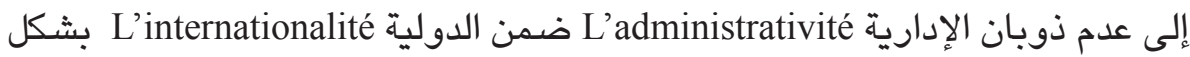
كلي، بحكم أن القضـاء الإداري يتمتع بالاختصاص الرقابي على الأحكام التحكيمية الصـادرة في إطار منازعات العقود الإدارية الكبرىى (62).

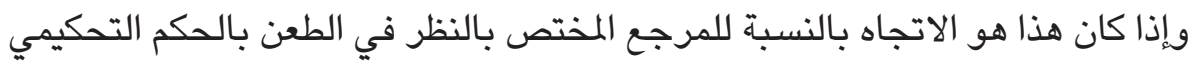

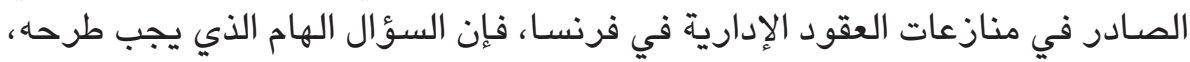

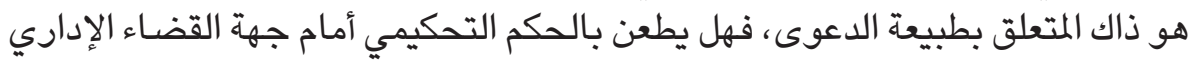

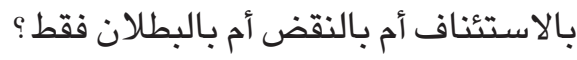
لقد ذهب مجلس الدولة الفرنسي في دراسته حول الوسـائل البديلة لفض المنازعات الإدارية إلى القول بادى الأمر بأن أحكام قانون المرافعات الملانية الفرنسي هي التي يجب إنب أن تطبق ، ومن ثم يباح للأطر اف إمكانية الطعن بالحكم التحكيمي إما بطريق الاستئناف، أو بطريق البطلان، ويكون ذلك أمام محكمة الاستئناف الإدارية التي صدر الحكم في دائرتها، والحكم الصـادر عن محكمة الاستئناف يكون قابلاً في هذه الحالة للطعن به أمام مجلس الدولة بالنقض (63). إن هـذا الاتجـاه كان قبل صـدور تقنين العدالة الإداريـة الفرنسي (64)، والذي جعل من

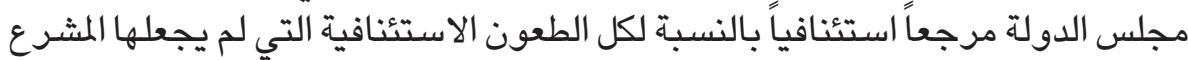
من اختصـاص محاكم الاستئناف الإداريسة(65)، حيث إن المـادة (321-2) من هذا التقنين تتص على اختصاص مجلس الدولة كمرجح استئنافي بالنسبة لكل الأحكام الصـادرة بالدرجة الأولى عن غير المحاكم الإداريةّ(66)، بمعنى أن كل حكم صادر بالدرجة الأولى بلى

(61) Yolka PH., Traité de droit administratif, op. cit., p. 625.

(62) Yolka PH., Ibid, p. 625.

(63) Conseil d'Etat, Régler autrement les conflits, Les études du conseil d'Etat, Paris, 1993, p. 100.

(64) وقد صدر هذا التقنين بموجب الأمر رقم 2000-387 . 293 بتاريخ 2000/5/4.

(65) Richer L., Droit des contrats administratifs, op. cit., p. 293. Lombard F., op. cit., p. 54. Lichére F., op. cit., p. 151.

(66) Delaunay B., Les sentences arbitrales concernant les personnes publiques en matière de commerce international: le contrôle du juge administratif, RFDA, Paris, 2017, p. 111. Chapus R., Droit du contentieux administratif, Montchrestien, Paris, 2006,12 ed., p. 266. 
يقبل الطعن بالاستئناف أمام مجلس الدولة، بما في ذلك الأحكام التحكيمية(67)، ماعدا

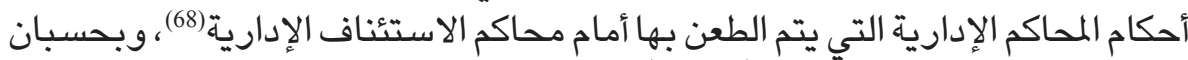
أن هيئة التحكيم تُعد قضاء إدارياً خاصـاً (69)، ومن ثم يُعد الحكم الصـادر عنها كأنه حكم صادر عن محكمة الدرجة الأولى (70).

ولقد تبنى مجلس الدولة الفرنسي ذلك بادى الأمر بالنسبة للأحكام التحكيمية الداخلية

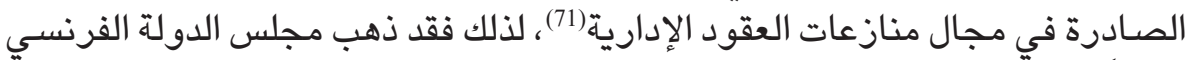
حديثاً إلى أن الطعن بالحكم التحكيمي إنما يتم بطريق الاستئناف(72)، ويشمل ذلك

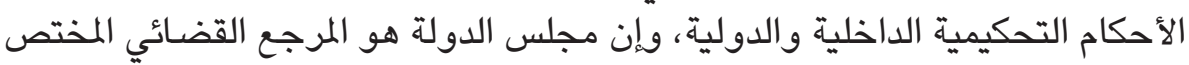
بالنظر به(73). وتكمن أهمية هذا الاجتهاد في أن مجلس الدولة الفرنسي اعترف للمرة الأولى بشكل صريح بأنه جهة استئناف بالنسبة لأحكام التحكيم الدولية الصـادرة في منازعات العقود الإداريـة(74)، وذلك بعد أن كان هذا التوجه مقتصراً على التحكيم الداخلي (75)، كما أن المجلس من خـلال هذا الاجتهاد مـارس للمرة الأولى رقابته على مضـمون حكم تحكيمي دولي صـادر في إطار منازعات العقود الإدارية (76). ولعل الأثر المترتب على رقابة الاستئناف هذه التي يمارسـها مجلس الدولة الفرنسي،

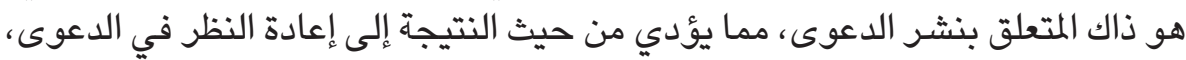
وصـدور حكم جـديـ(77)، مـع مـا يـؤدي إليه ذلك مـن إزالـة للأسـاس القانوني للحكي

(67) Odent R., Contentieux administratif, Dalloz, Paris, T1, p. 700.

(68) Muscat H., op. cit., p. 2245.

(69) Juridiction administrative spécialisée.

(70) Guettier.Ch, op. cit., p. 518. Muscat H., op. cit., p. 2245.

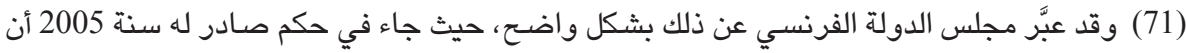

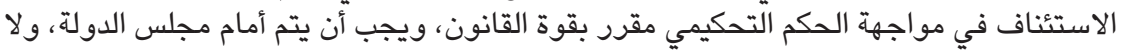

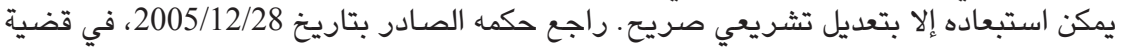
اتحاد نقابات القضاة الإداريين Anion syndicat des Magistrats administratifs، .A. J. D.A, 2006

(72) C.E, Ass, 9-11-2016, Société Fosmax, A.J.D.A, Paris, 2016, p. 2133.

(73) C.E, 19-4-2013, Syndicat mixte des aéroporté de Charent, précité.

(74) Muscat H., op. cit., p. 2245.

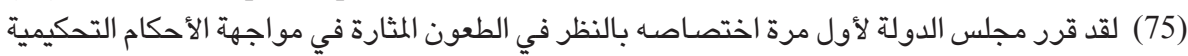

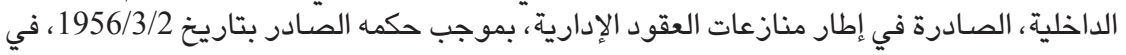

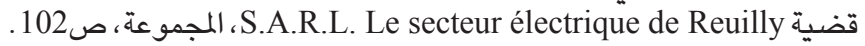

(76) Delaunay B., op. cit., p. 112.

(77) Ibid, p. 115. 
التحكيمي (78)، فيصير عندئن القاضي الإداري هو قاضي التحكيم لا قاضي الحكم (79)،

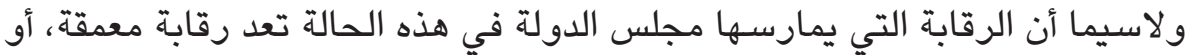

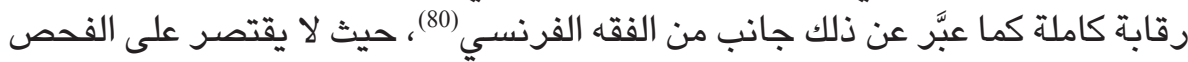

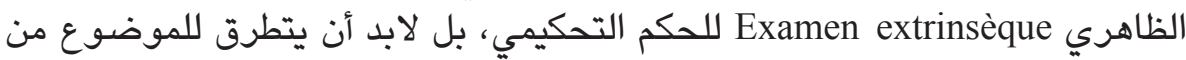

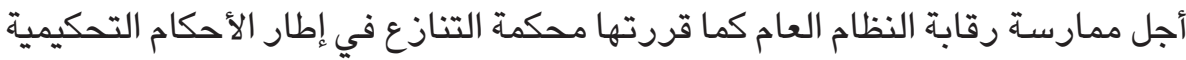

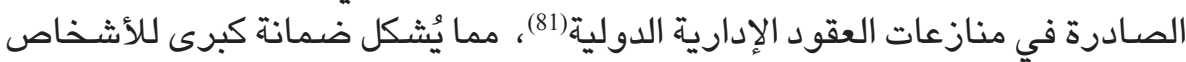

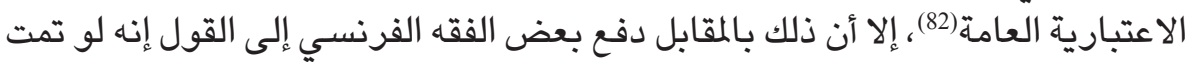

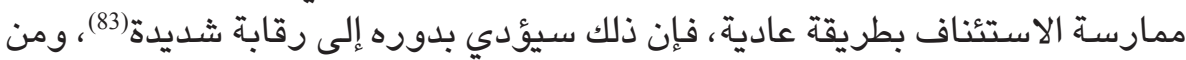

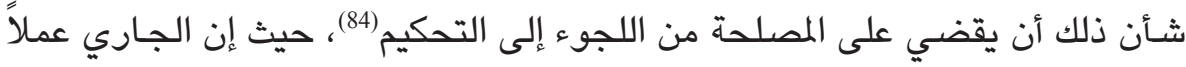

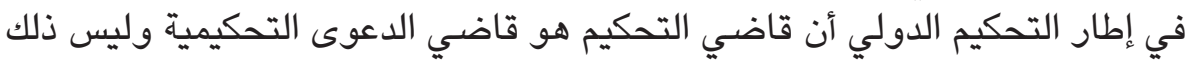

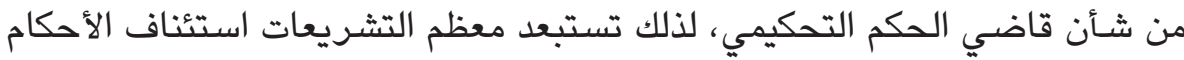

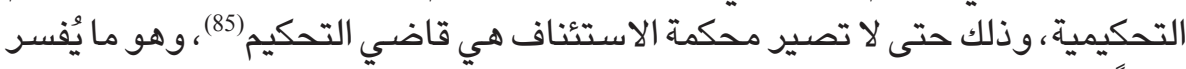

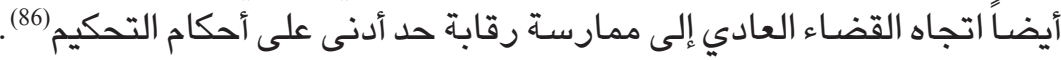

وحتى عندما يبسط القضاء العادي رقابته على أحكام التحكيم الدولية من حيث مراعاتها

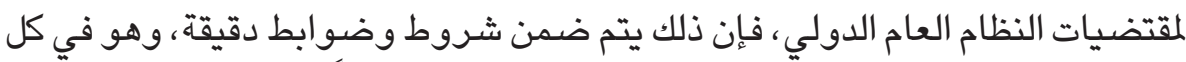

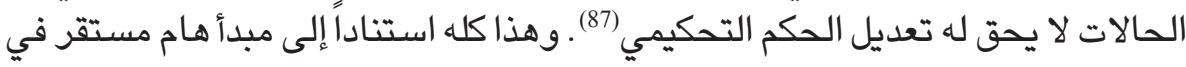

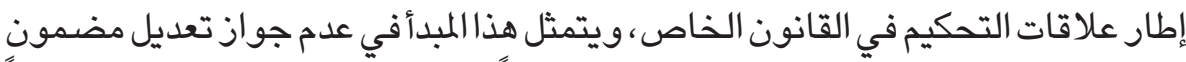

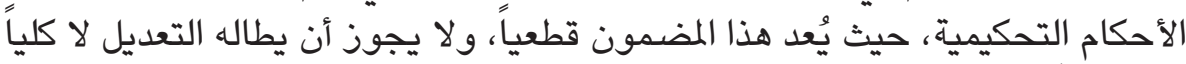

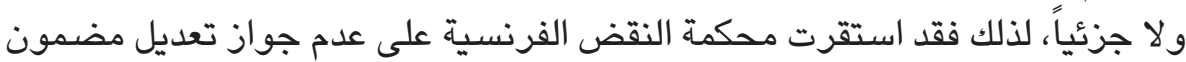

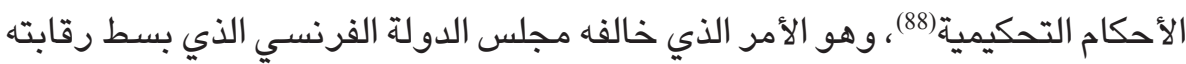

(78) Muscat H., op. cit., p. 2245.

(79) Rouault D., op. cit., n³.

(80) Chapus R., op. cit., p. 266.

(81) Lumaire S., op. cit., p. 2236. Muscat H., op. cit., p. 2245.

(82) Ibid, p. 2245.

(83) Lumaire S., op. cit., p. 2235.

(84) Muscat H., op. cit., p. 2245.

(85) Rouault D., op. cit., $n^{\circ} 3$.

(86) Lumaire S., op. cit., p. 2235.

(87) Rouault D., op. cit., $\mathrm{n}^{\circ} 3$.

(88) Cass.Civ, 1-10-2005, n02-13-152, D, 2006, p. 199. Cass.Civ, 12-2-2014, ${ }^{\circ} 10$ 17.076, D. 2014, p.490. 


$$
\text { على الحكم التحكيمي ولو كان دولياً مما أدى إلى تعديل في مضمونه(89). }
$$
وعلى كل حال، ونظراً إلى الانتقادات الموجهة إلى رقابة الاستئناف التي يمكن أن تمارس

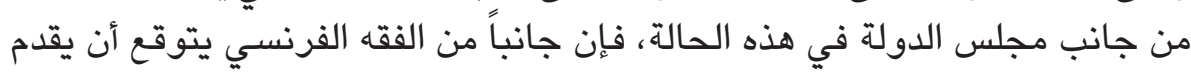

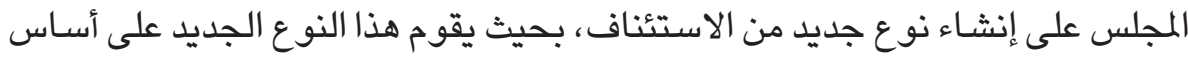
الموازنة بين رقابة النظام العام كما قررتها محكمة التنازع من جهة ، والاحتفاظ بالحكم التحكيمي من جهة أخرى (90)، وهو ما يعني أن يوجد الاستئناف كطريق للطعن بالحكم التحكيمي، لكن دون تحقق نتائجه (91).

ومن الملاحظ أن هناك مشروع قانون يتعلق بالتحكيم في منازعات الأشخاص الاعتبارية العامـة في فرنسـا، وقد تبنى هذا المشـروع رقابة النقض على الأحكام التحكيمية كافة، وتمارس هذه الرقابة من قبل مجلس الدولة، ومع إمكانية التطرق للموضوع، بناء على هلى طلب مسبب من قبل الأطراف، وقد لاقى هذا الحل العديد من الانتقادات، كونه يتيح للإدارة

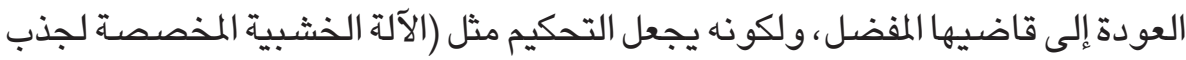
العصـافير) كما عبَّر عن ذلك جانب من الفقهـ(92).

(89) Delaunay B., op. cit., p. 114.

(90) Rouault D., op. cit., n³ ${ }^{\circ}$ Delaunay B, op. cit., p.115.

(91) Delaunay B., op. cit., p. 115.

(92) Yolka PH., Traité de droit administratif, op.cit., p. 626. 


\section{المبحث الثاني}

\section{تدخل القضاء الرسمي في نطاق إكساء الحكم التحكيمي \\ صيغة التنقيذ}

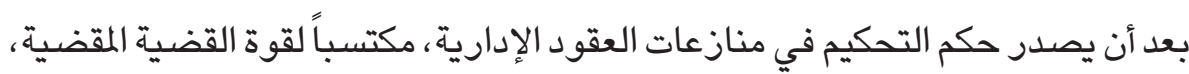

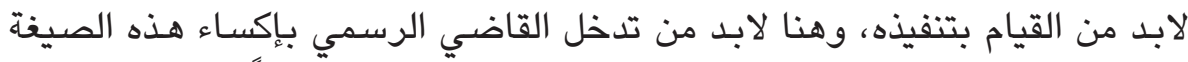

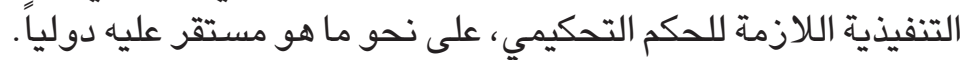

وفي التشريعات الداخلية للدول، وبالنسبة للأحكام الصـادرة في منازعات العادئ العقود

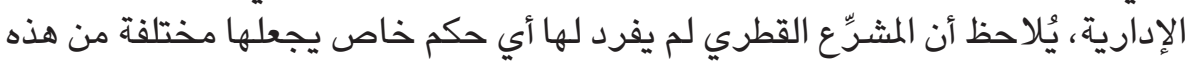

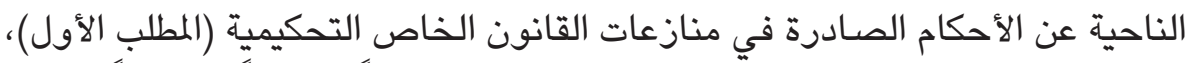

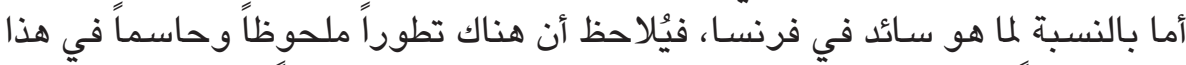

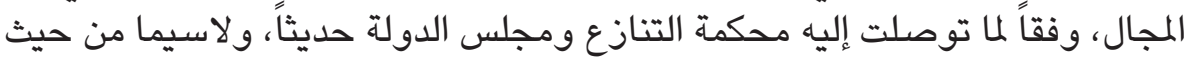

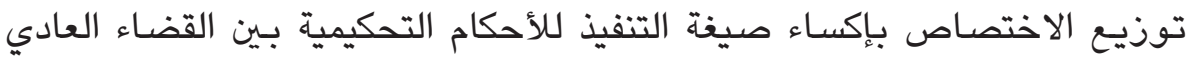

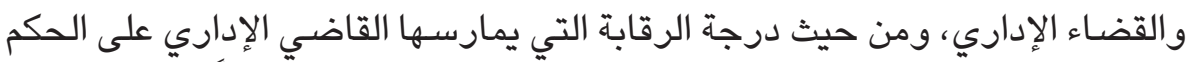

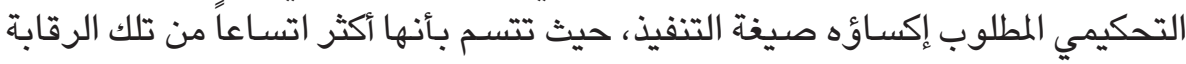

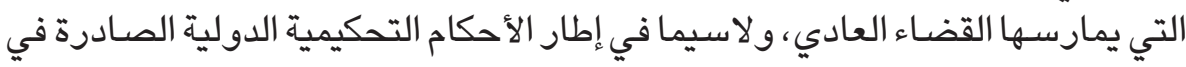
منازعات العقود الإدارية (المطلب الثاني).

\section{المطلب الأول \\ الوضع في القانون القطري: \\ عدم اختصاص القضاء الإداري بإكساء صيختة التنفيذ}

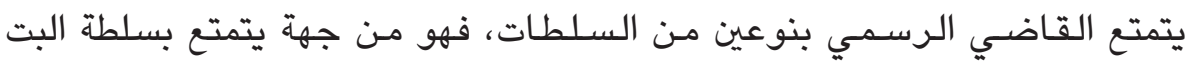

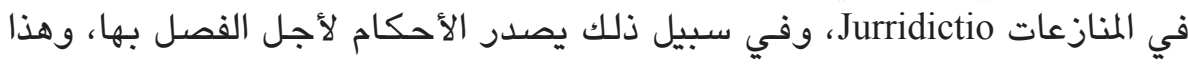

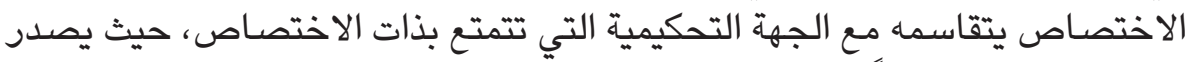

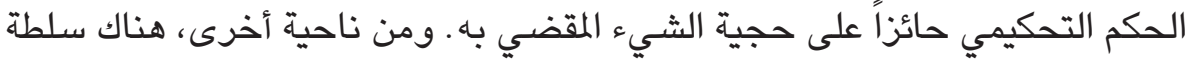

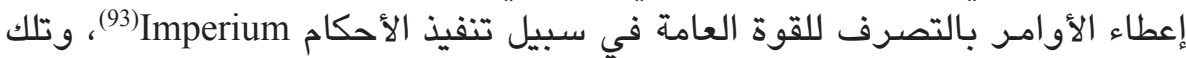

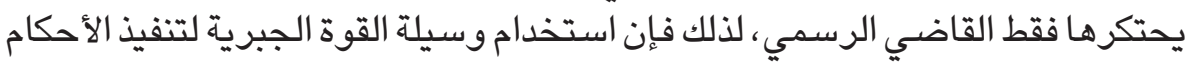

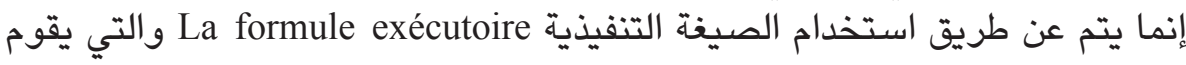

(93) Najib M. M, L'intervention du juge dans la procédure arbitrale, Thèse, L'univessité de Bordeaux France, 2016, p.56. 


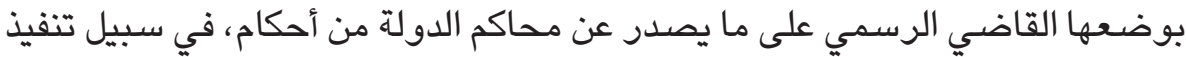
الأحكام باستخدام القوة والجبر إن اقتضى الأمر ذلك الك (94).

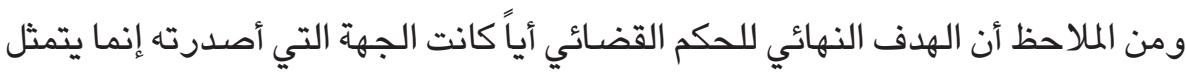

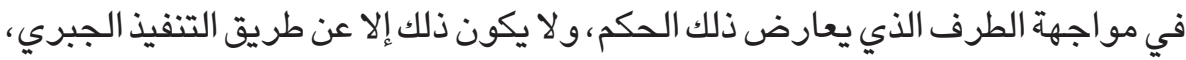

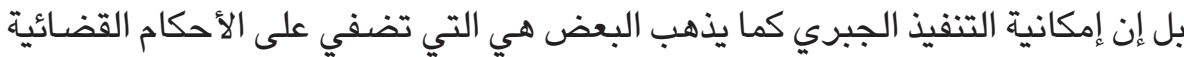

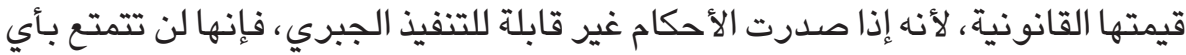

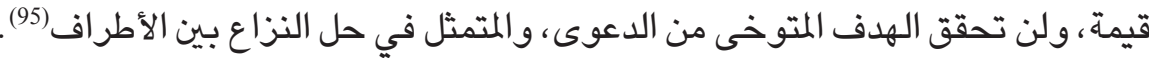

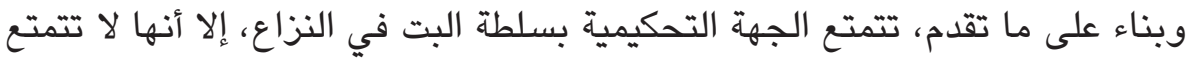

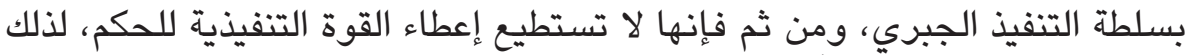

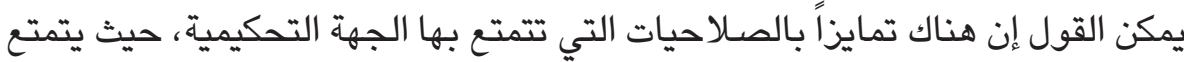

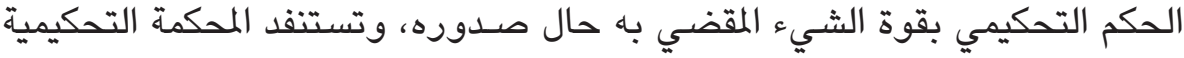

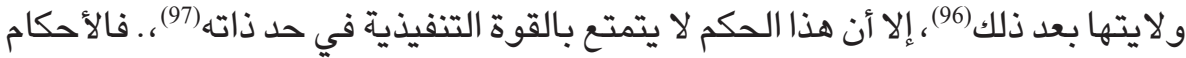

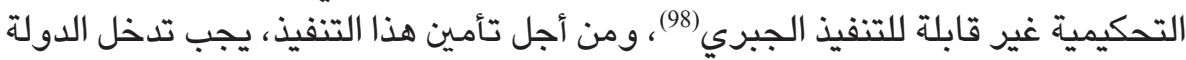
ممثلة بقضائها الرسمي، وهو الذي يعطي الحكم التحكيمي القوة التنفيذية من خلال سلطته (99).

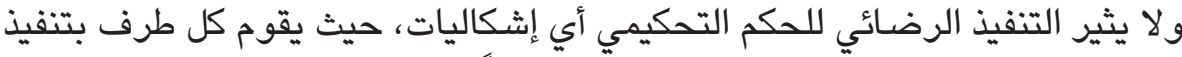

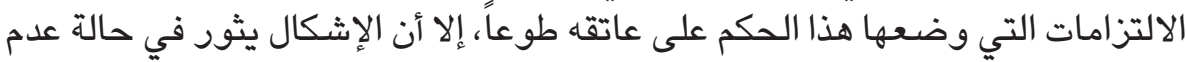

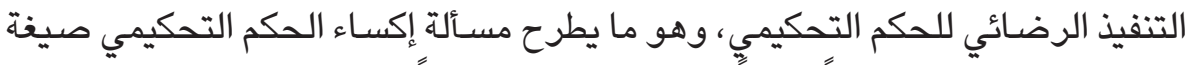

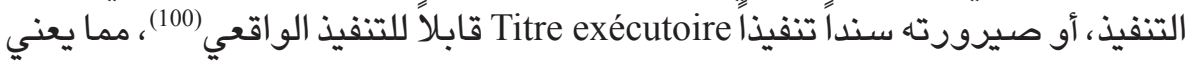

(94) Ibid, p. 57.

(95) Ibid, p. 56.

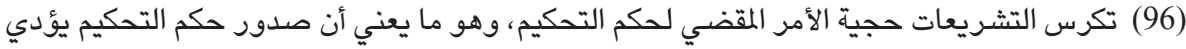

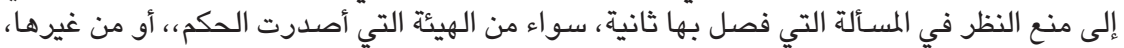

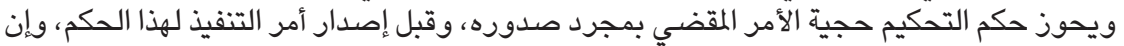

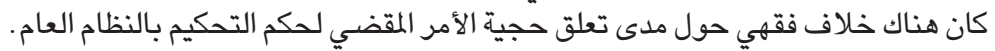

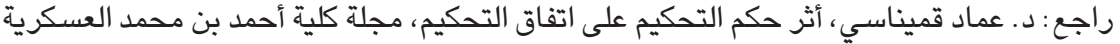

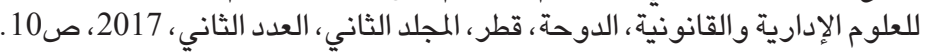

(97) Liu. O, L'exécution des sentences arbitrales étrangers, Etude comparative entre la France et la Chine, Thèse, université Paris II, Panthéon-Assas, 2016, p. 96.

(98) Braconnier.S, Précis du droit des marchés publics, Le Moniteur, Paris, 2007, p. 450.

(99) Najib M. M, op. cit., p. 56. Liu. O, op. cit., p. 97.

(100) Liu. O, op. cit., p. 98. 


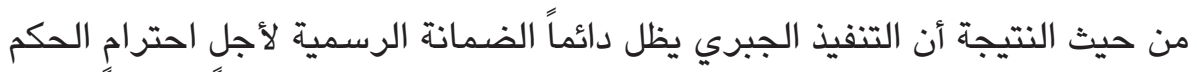

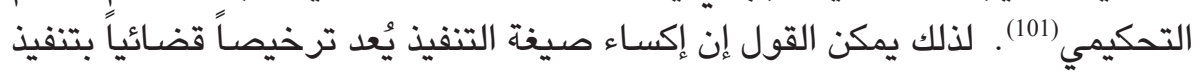
عمل لا يتمتع بقوة التنفيذ ضمن النظام القانوني الداخلي للدولة التي يطلب التنفيذ يُّني ترخي

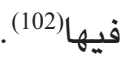

وبناء على ما تقدم ، فقد سـارت القوانين الدولية والداخلية على إعطاء القضـاء الوطني مهمة

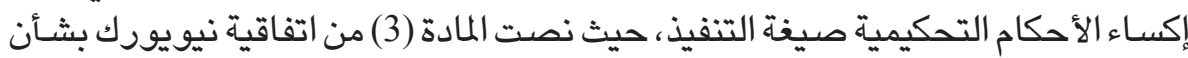

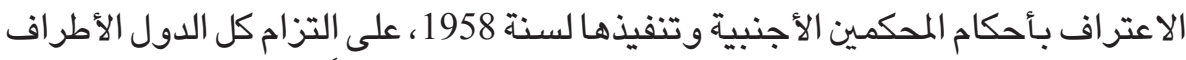

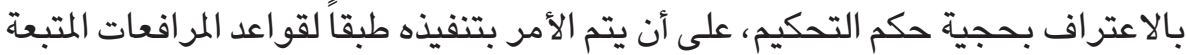
في الدولة التي يطلب التنفيذ في إقليمها. وقد سار قانون التحكيم القطري في هذا الاتجاه أيضًاً، حيث نصت المادة (35) من قانون

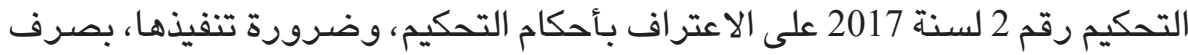

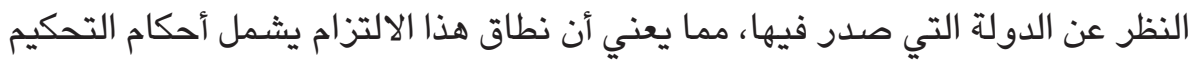

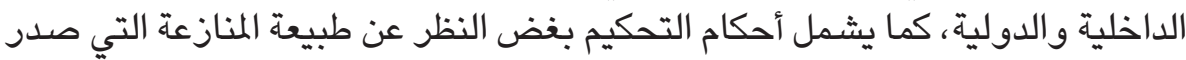

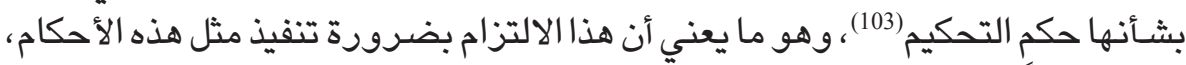

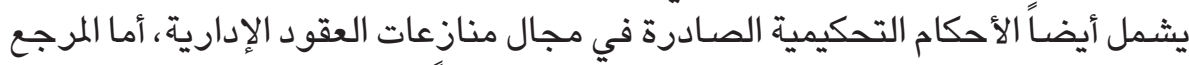

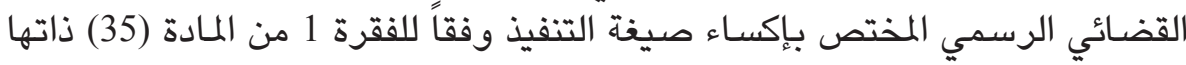

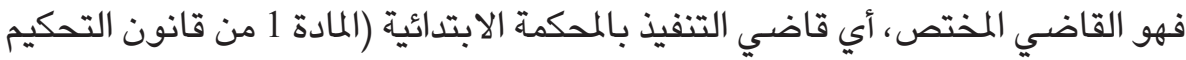

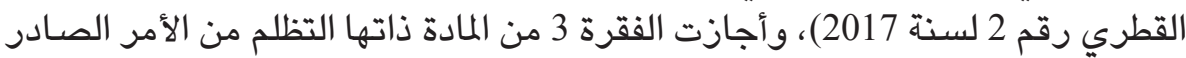

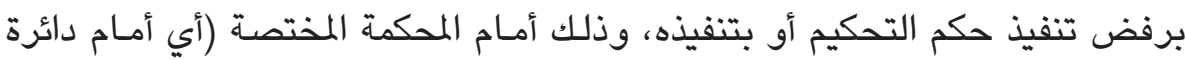

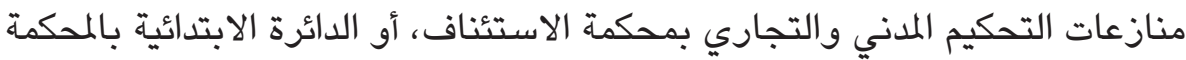
المدنية والتجارية لمركز قطر للمال، بناء على اتفاق الأطراف) (104).

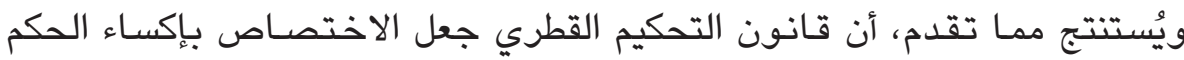

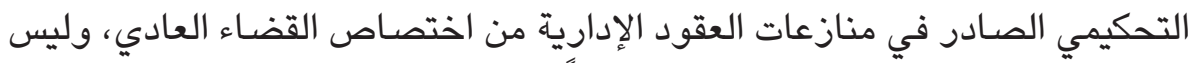

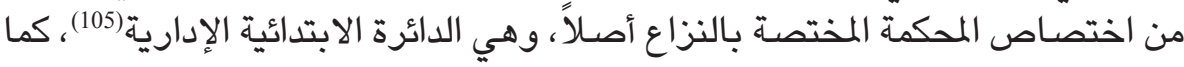

(101) Ibid, p. 99.

(102) De Laubadère A. et Delvolvé P. et Moderne F., Traité des contrats administratifs, T2, L.J.D.G, Paris, 1984, p. 964.

(103) د. عماد قميناسي، تنفيذ حكم التحكيم، المؤسسة الحديثة للكتاب، بيروت، 2018، 2017، ص9.

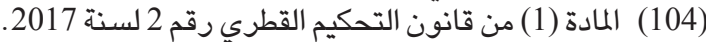
(105) الفقرة 5 من المادة (3) من القانون التون رقم 7 لسنة 2007 204 المتعلق بالفصل في المنازعات الإدارية. 
أن مرجع الطعن بالأمر الصـادر برفض إكسـاء صيغة التنفيذهي المراجع القضـائية العادية وليس الدائرة الإدارية الاستئنافية (106).

ويجوز للمرجح القضـائي المختص بإكسـاء الحكم صيفة التنفيذ رفض إصدار الأمر بذلك،

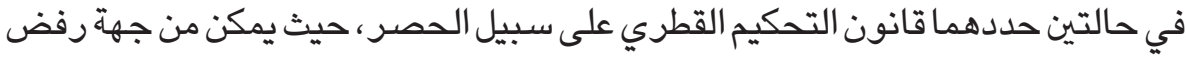
إكسـاء الحكم التحكيمي الصيغة التنفيذية بناءً على طلب الطرف المطلوب التنفيذ ضـده، إذا تام بإثبات تحقق إحدى الحالات التي حددها القانون على سيبل الحصر أيضـاً (107). كما أوجب قانون التحكيم القطري من جهة أخرى على القاضي المختص أن يرفض إكساء

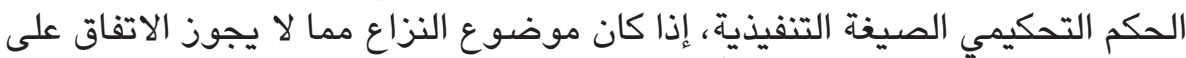
الفصل فيه عن طريق التحكيم وفقاً لقانون الدولة، أو إذا كان الاعتراف بالحكم أو تنفيذه يتعارض مع النظام العام للدولة(108).

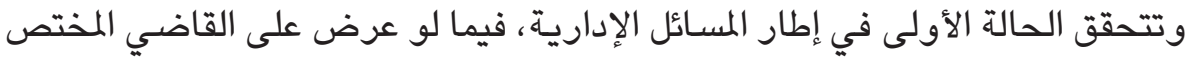

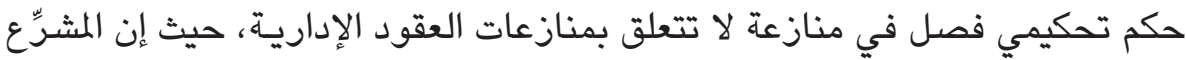

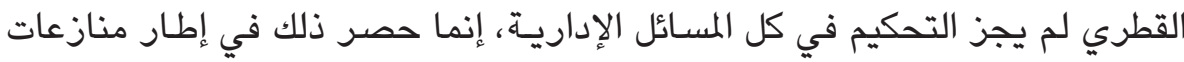
العقود الإدارية فقط (109)، ومن ثم إذا فصل حكم التحكيم في مسـائل خارج هذا النطاق، أي في منازعات إدارية لا تتعلق بالعقود الإدارية، فلا يجوز عندئذ للقاضي المختص إكساء

(106) المادة (8) من القانون رقمٍ 7 لسنة 2007 المتعلق بالفصل في المنازعات الإدارية. (107) وتتمثل هذه الحالات وفقاً للفقرة الأولى من المادة (35) من قانون التحكيم القطري رقات المّان 2 لسنة 2017 فيما يلي: وتئي

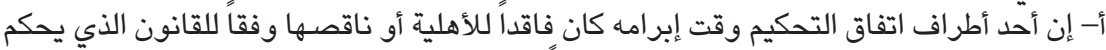

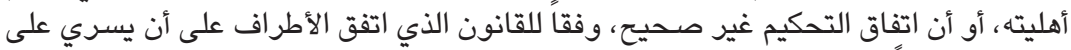

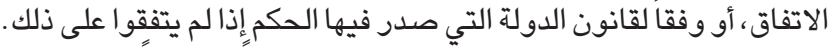

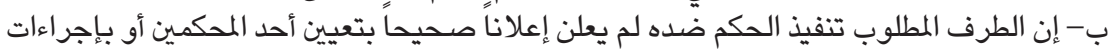

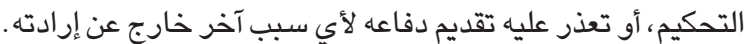

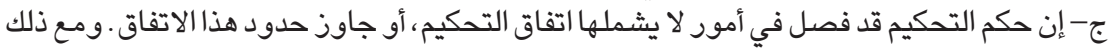

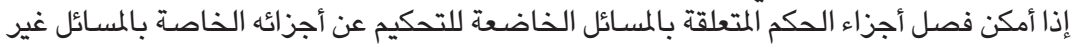
الخاضعة له، يجوز الاعتراف أو تنفيذ أجزاء حكم التحكيم التي فصلت في الأمور التي يشملها التها

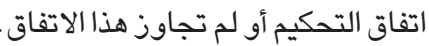

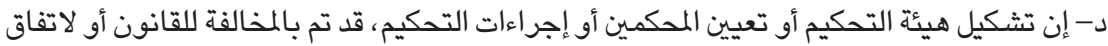

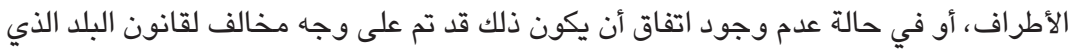
جرى فيه التحكيم. هـ- إن حكم التحكيم لم يعد ملزماً للأطرافٍ، أو قد تم إبطاله أو إيقاف تنفيذه من قبل إحدى محاكم

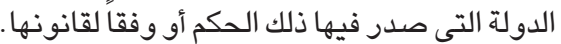

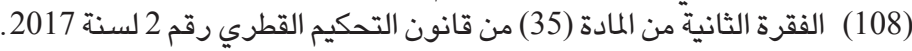
(109) الفقرة الثانية من المادة (2) من قانون التحكيم القطري (35) من قانون التحريم 2 لسنة 2017. 


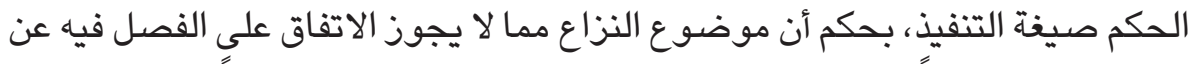

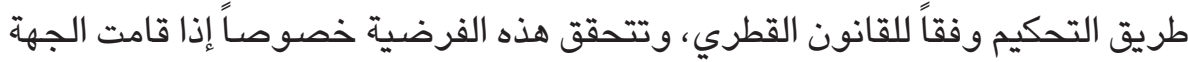

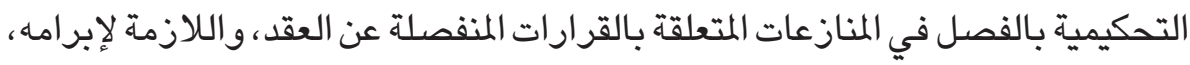

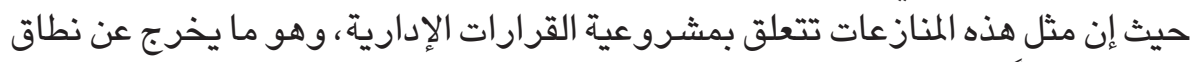

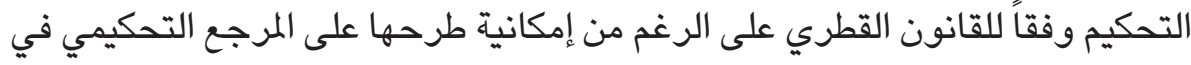

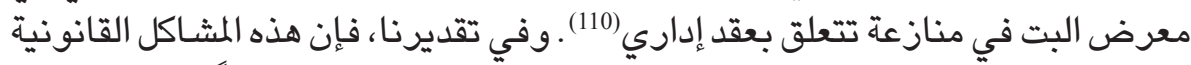

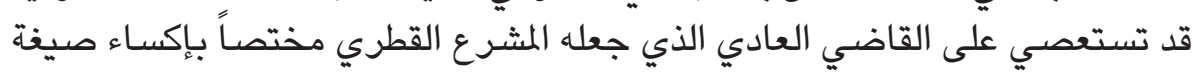

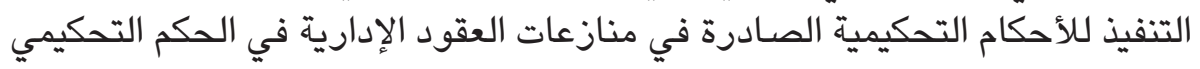

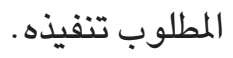

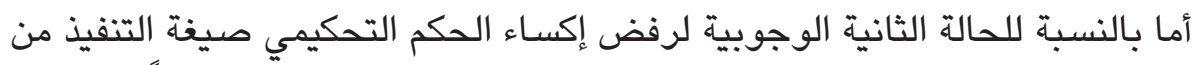

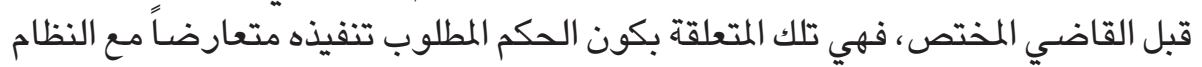

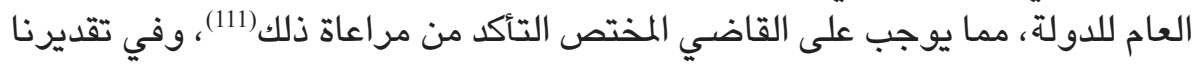

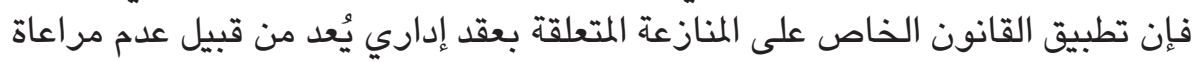

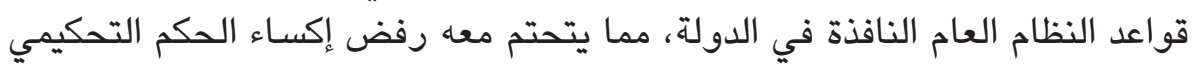

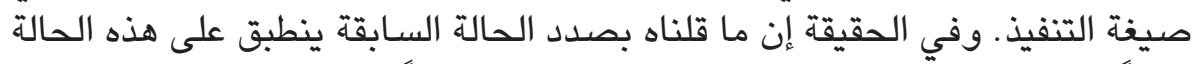

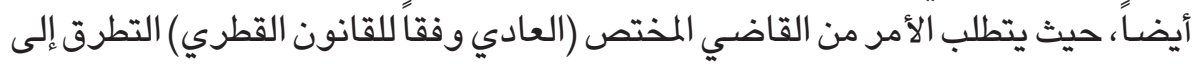

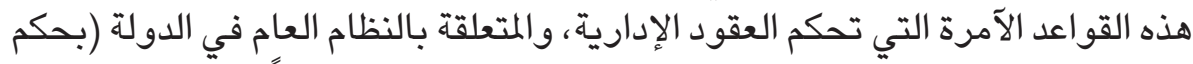

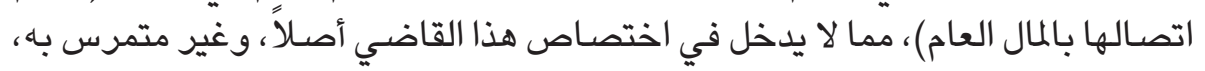

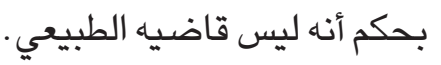

\section{المطلب الثاني}

\section{الوضع في القانون الفرخسي: اختصاص القضاء الإداري بإكساء الحكم التحكيمي صيغة التنفيذ}

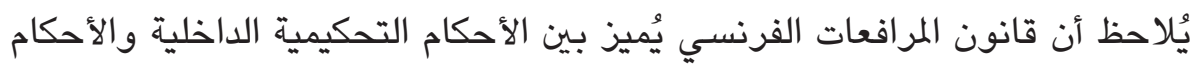

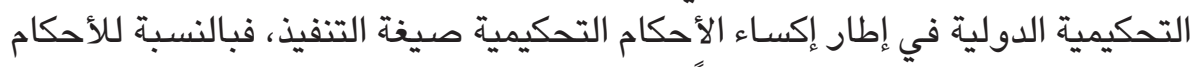

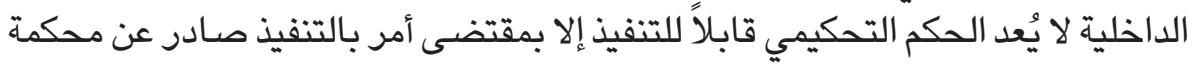

(110) راجع في القرارات المنفصلة عن العقد : د. مهند نوح، الإيجاب والقبول في العقد الإداري، منشورات

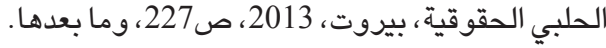

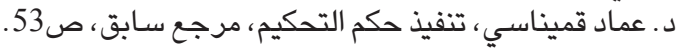




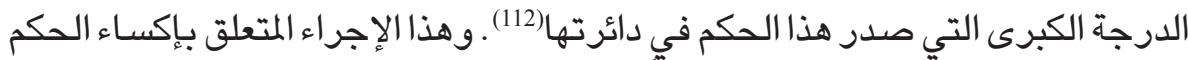

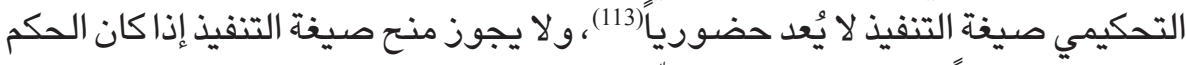

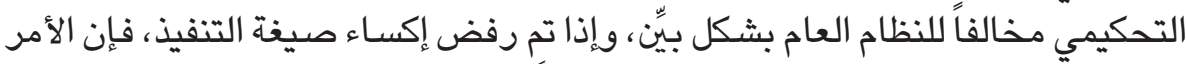

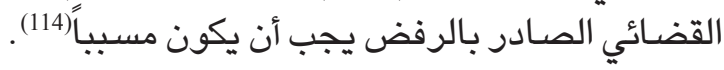

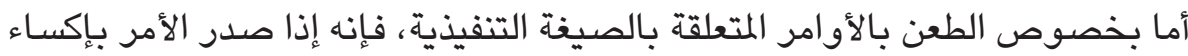

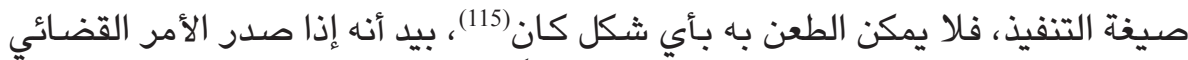

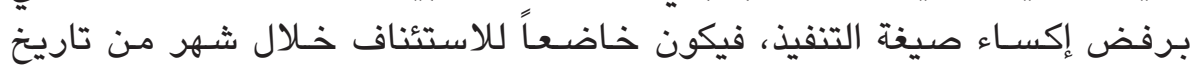
تبليغه(116).

أما على صعيد التحكيم الدولي، فإن الحكم التحكيمي لا يكون قابلاً للتنفيذ الجبري إلإ

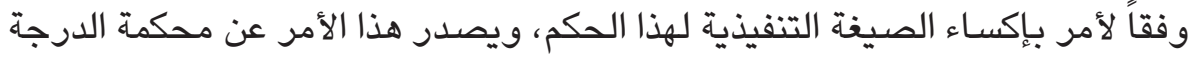

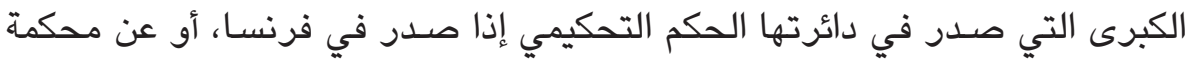

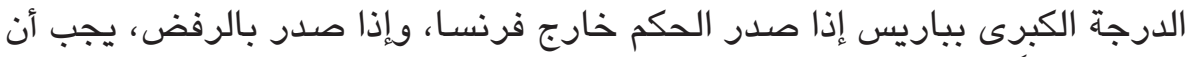
يكون مسبباً (117).

ولا يجوز الطعن بالاستئناف بالأمر القضائي الصادر بإكساء الحكم صيغة التنفيذ(118)، إلا أنه يجوز الطعن بالاستئناف بالأمر القضائي الرافض لذافئل الذالك، ويمكن أن يتم ذلك خلال شـهر من تاريخ تبليخ الحكم المذكور (119). ويُلاحظ أن محكمة الاستئناف المختصة، هي محكمة الاستئناف التي تراقب أحكام (112) المادة (1487) من قانون المرافعات الفرنسي المدرجة بمقتضى المرسوم رقم 48-2011/11،

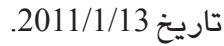

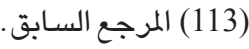
(114) المادة (1488) من قارجان المانون المرافعات الفرنسي المدرجة بمقتضى المرسوم رقم 48-2011، تاريخ (11) 2011/1/13.

(115) المادة (1499) من قاريخن المرافعات الفرنسي المدرجة بمقتضى المرسوم رقم 48-2011/2011، تاريخ 2011/1/13. (11) من

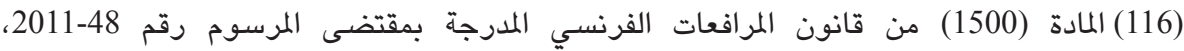

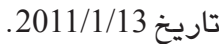

(117) المادة (1516) من قاريخ (2013/13/نانون المرافعات الفرنسي المدرجة بمقتضى المرسوم رقم 48-2011،

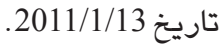

(118) المادة (1524) من قاريخ 2011/13/13ن المرافعات الفرنسي المدرجة بمقتضى المرسوم رقم 48-2011،

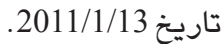
(119) المادة (1523) من قاريخ 2011/13/نان المرافعات الفرنسي المدرجة بمقتضى المرسوم رقم 48-2011،

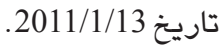


محكمة الدرجة الكبرى المختصـة، وذلك إذا صدر الحكم التحكيمي في فرنسا، أو محكمة

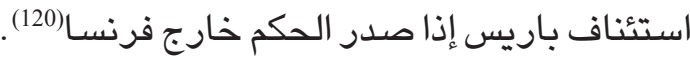

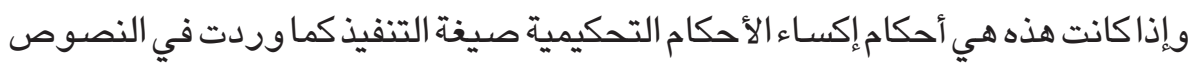

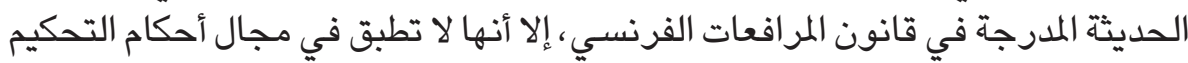

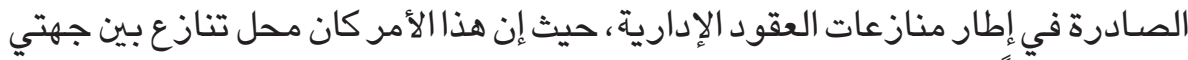

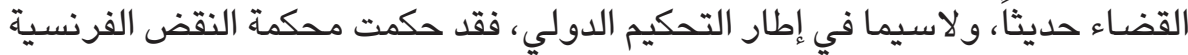

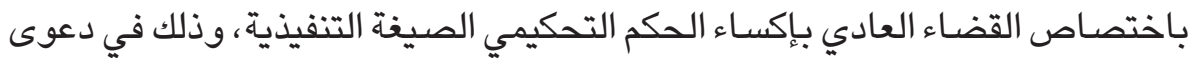

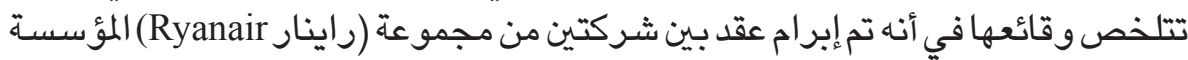

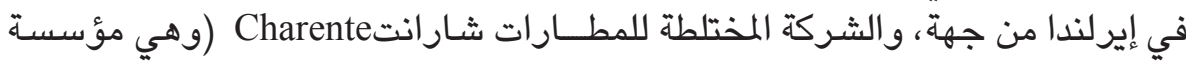

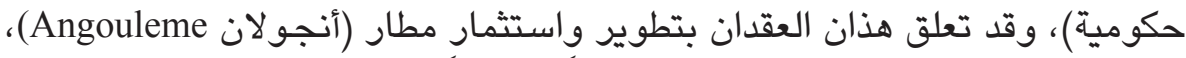

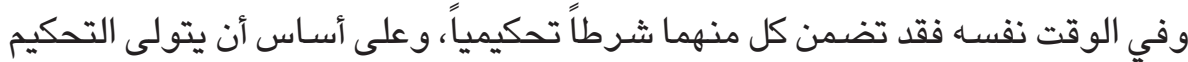

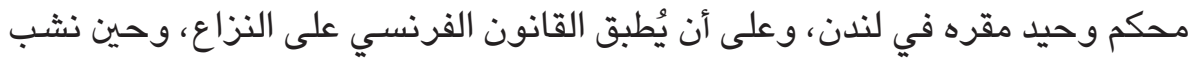

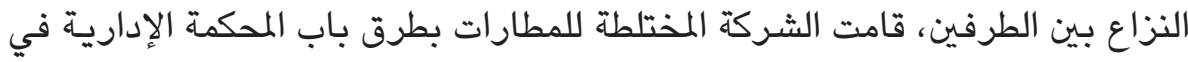

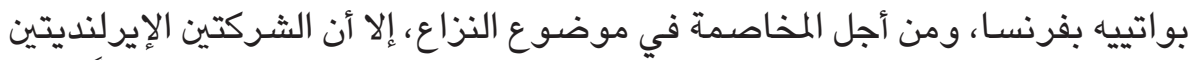

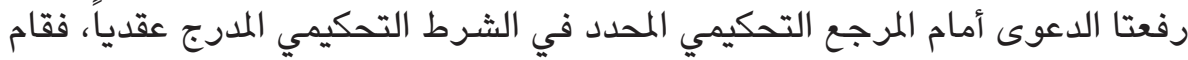

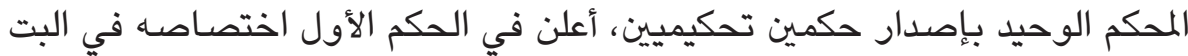

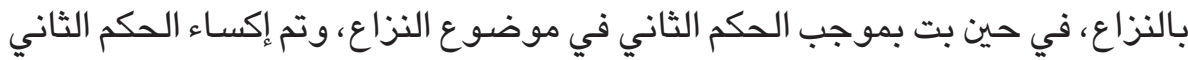

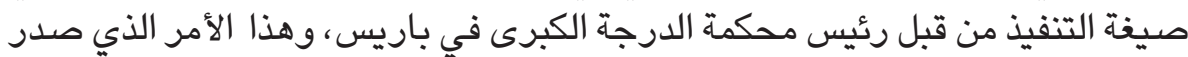
بالإكساء كان محلاً للاستئناف (121).

وحين تم استئناف الأمر الصـادر بإكسـاء صيغة التنفيذ أمام محكمة الاستئناف، أصدرت

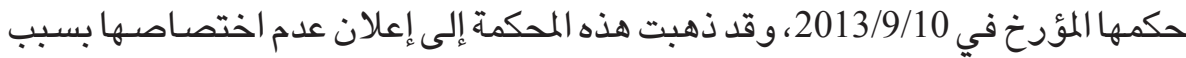

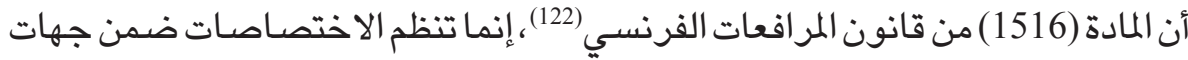

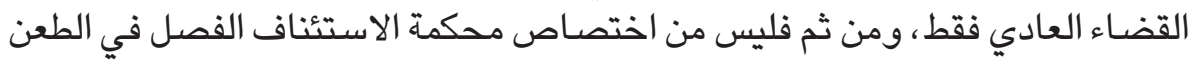

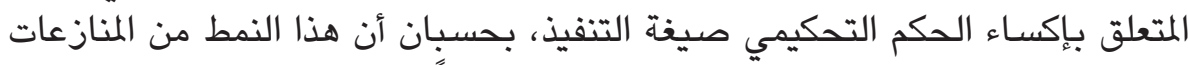

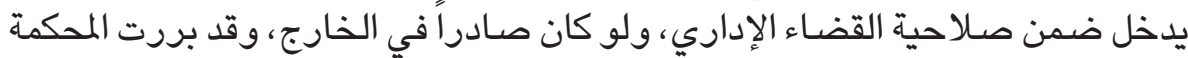

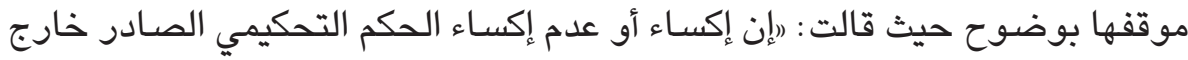

(120) المادة (1526) من قانون المرافعات الفرنسي المدرجة بمقتضى المرسوم رقم 48-2011/11، تاريخ 2011/1/13.

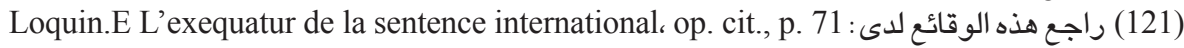
(122) وهي المادة التي تتعلق بإكساء الأحكام التحكيمية الدولية صيغة التنفيذ. 
فرنسا فيغة التنفيذ، إنما يخضـ لذات شروط الطعن بالحكم التحكيمي الدولي الصـادر في فرنسا، (123).

ومن الواضح أن محكمة الاستئناف قد تأثرت في حكمها هذا باجتهاد محكمة التنازع

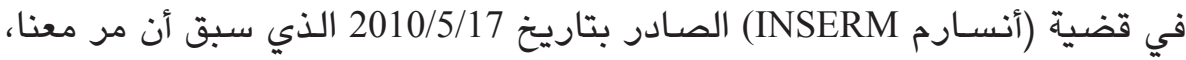

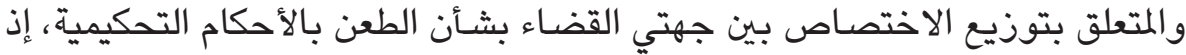

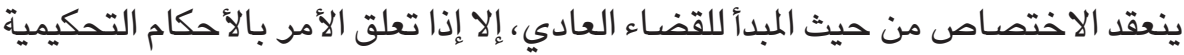

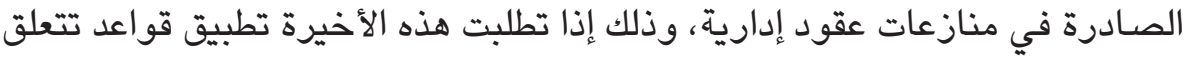

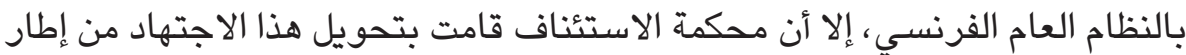

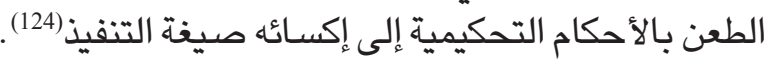
ولكن على الرغم مما ذهبت إليه محكمة استئناف باريس، فإن محكمة النقض قامت

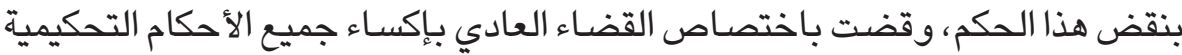

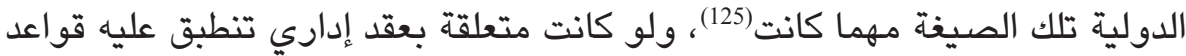
النظام العام المتعلقة بالقانون الإداري الفرنسية (126).

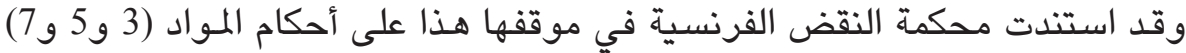

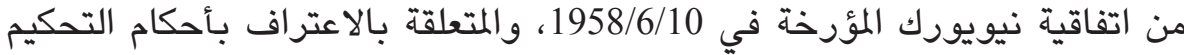

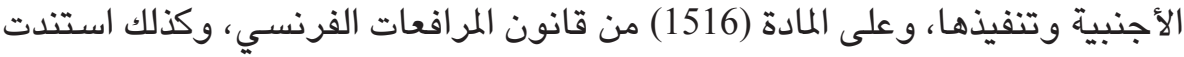

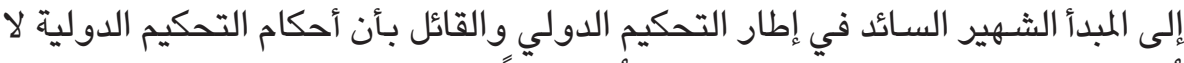

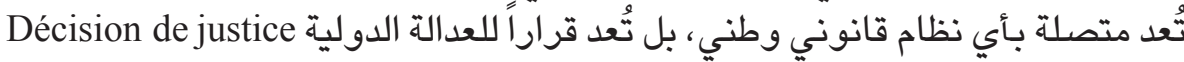
${ }^{(127)}$ international

وتعقياً على ما ذهبت إليه محكمة النقض الفرنسية، يرى بعض الفقه الفرنسي أنه إذا

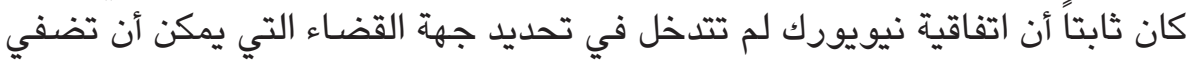

(123) C.A, Paris, 10-9-2013, R. arb., 2014, 153, Note: M. Lauzouzi.

(124) Loquin F., L'exequatur de la sentence international, op. cit., p. 72.

(125) Odinet G. et Roussel S., La jurisprudence INSERM, embrasse l'exequatur, A.J.D.A, Paris, 2017, p. 985.

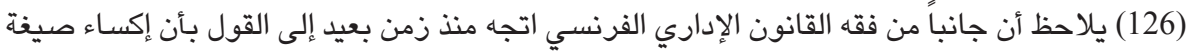

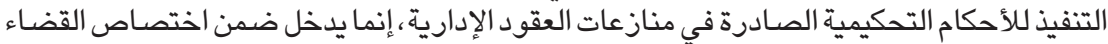

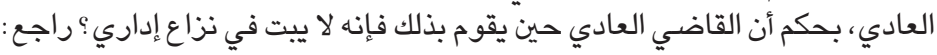

De Laubadère A. et Delvolvé P. et Moderne F., op. cit., p. 964.

(127) Cass.civ,I, 8-7-2015, n 13-25,846, FSBRI, Soc. Ryanair et A.C - Syndicat mixte des aéroports de Charente, A.J.D.A, 2015, 1396, D,2015, 1547. 
الصيغة التنفيذية على الحكم التحكيمي(128)، وهو ما يعني أن كلاً من الدول الموقعة

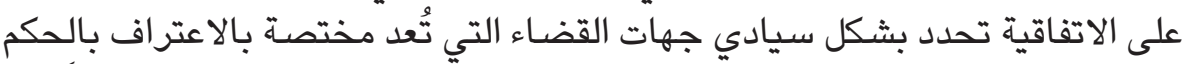
التحكيمي الدولي وتنفيذه (129)، إلا أن اتفاقية نيويورك تتص في المادة (3) منها أيضًاً على لـي التزام يقع على عاتق الدول الأطراف، ويتمثل هذا الالتزام بعدم جواز فرض شئه شروط

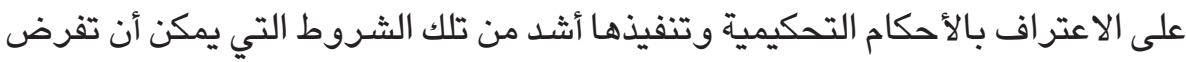
لأجل الاعتراف بالأحكام التحكيمية الداخلية وتتفيذها، وهو الأمر غير المتحقق في حال انعقد الاختصاص للقضاء الإداري، بإكساء صيغة التنفيذ للأحكام التحكيمية الدولية في مجال العقود الإداريـة، لأن رقابة هذا القضـاء تُعد أكثر شدة من تلك الرقابة التي

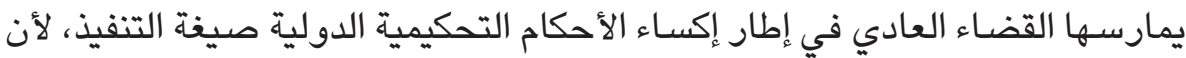
القضـاء الإداري سيتأكد عندئذ من احترام المحاكم التحكيمية لأحكام النظام العام المتعلق بالقانون الفرنسي، أما القضـاء العادي فإنها وفقاً لأحكام الفقرة 5 من المادة (1520) من قانون المرافعات الفرنسي ييسط رقابته فقط على الأحكام التحكيمية للتأكد من مراعاتها للنظام العام الدولي (130).

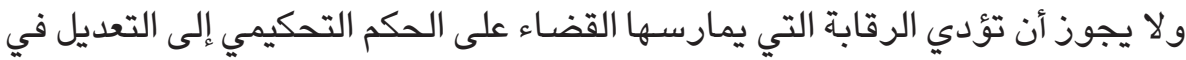
موضوع هذا الحكم (131)، وفي سبيل تحاشي ذلك، فإن القضـاء العادي في فرنسـا يأخذ

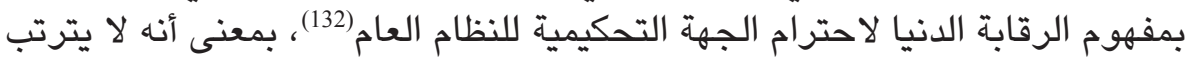

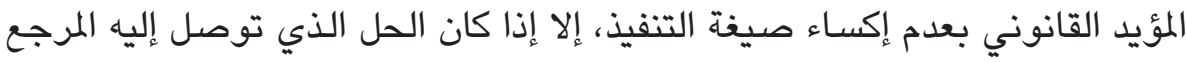
التحكيمي يصطلمم في حد ذاته بالنظام العام (133). وهذا يعني أن رقابة النظام العام كما أقرَّها القضـاء العادي في فرنسـا عند إكسـاء الأحكام التحكيمية الصيفة التنفيذية، إنما هي رقابة المطابقة الظاهرة Conformité apparente محكمة التحكيم في حكمها يتطلب تطبيق النظام العام ولم تقم المحكمة المذكورة بتطبيقه،

$$
\text { (128) تنص المادة (3) من اتفاقية نيويورك على ما يلي: }
$$

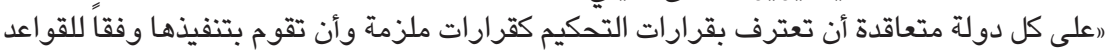

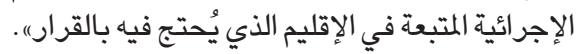

(129) Loquin F., L'exequatur de la sentence international, op. cit., p. 72.

(130) Ibid, p. 72.

(131) Weiller L., 'Exequatur des sentences arbitrales internationales, Procédures $n^{\circ} 7$, Juillet 2017, comm. 162.

(132) «Conception minimaliste du contrôle du respect de l'ordre public». De Laubadère A. et Delvolvé P. et Moderne F., op. cit., p. 964.

(133) C. A, Paris, 4-12-1978, R.arb, 1979, p. 322, Note: Boitard M. C. A, Paris, 14-4-1993, R.arb, 1994, p. 164, Note: Jarrasson Ch.

(134) Loquin F., L'exequatur de la sentence international, op. cit., p. 73. 
فذي هذه الحالة تبسط رقابة القضـاء العادي عند إكساء صيغة التنفيذ، ولكن لا تبسط

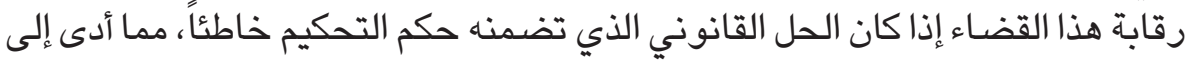
مخالفة النظام العام، لأنه في هذه الحالة ستؤدي الرقابة إلى تعديل الحكم التحكيمي (135)، لذلك نجد أن محكمة النقض الفرنسية، قيَّدت الرقابة في هذه الحالة بالتجاوز (الجسيمب و الفعال) على النظام العام (136).

ومن ناحية أخرى، ويتحليل المادة (5) من اتفاقية نيويورك سـالفة الذكر ، فإنها يحظر على القاضي المختص بإكسـاء الحكم التحكيمي الدولي صيغة التنفيذ أن يُعدّل في مضدمون هذا الحكم، وهو ما قد يقومٍٍ به القاضي الإداري في حال اختص بإكسـاء الحكم التحكيمي

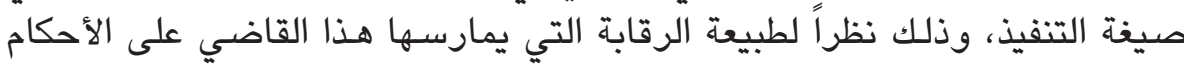
التحكيمية فيما يتعلق بتقيدها بأحكام النظام العام الفرنسي واجبة التطبيق في إطار منازعات العقود الإداريّة، وذلك على عكس اتجاه القضـاء العادي في فرنسـا، الذي يُحسِّن الأحكام التحكيمية الصـادرة في الخارج من كل مساس بموضسوعها، في معرض إكساء

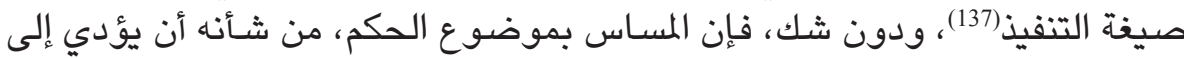
إصدار حكم جديد في موضسوع النزاع من قبل القاضي المختص بإكسـاء صيغة التنفيذ، ومن ثم يحل تقدير هذا الأخير محل التقدير الذي قامت به الجهة التحكيمية عندما فصلت في النزاع(138)

إلا أنه على الرغم من ذلك، وعلى الرغم مما اتجهت إليه محكمة النقض الفرنسية، فإن

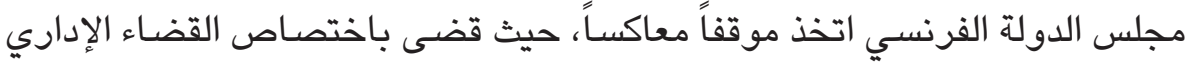
بإكسـاء الأحكام التحكيمية الدولية صيغة التنفيذ، والصـادرة في منازعات العقود الإدارية (139)، بحيث يكون اختصـاص القضـاء العادي هو الأصل حسب قانون المرافعات،

(135) Cass.civ1, 25-10-2005, n 02-13-252, D, 2006, p.199. Cass.civ1, 12-2-2014, n¹0076-17, D,2014, p.490.

(136) Cass.civ1, 4-6-2008, n 06-15-320-D, 2008, p.1684, obs. Delpech X, R.T.D.C, 2008, 518, obs. Loquin E.

(137) Delaunay. B, op. cit., p.114.

(138) Loquin E, L'exequatur de la sentence international, op. cit., p.72.

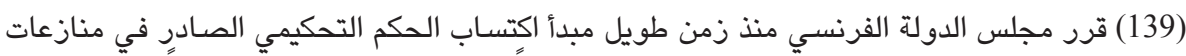

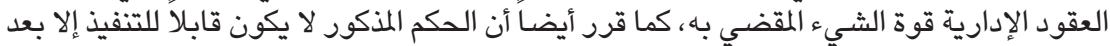
إكسائه صيغة التنفيذ، راجيع: الإداءئ

C.E, 21-4-1943, Société Les ateliers de construction du Nord de la France, R. p.107.

Odent. R, op. cit., p.700 وراجع في الفقه: 
واختصاص القضاء الإداري هو الاستثناء، وذلك في مجال العقود التي تثير قواعد النظام العام المتعلقة بالقانون الإداري (140).

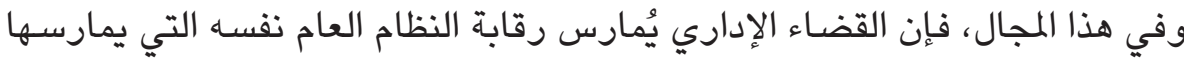

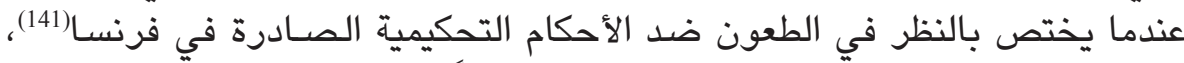

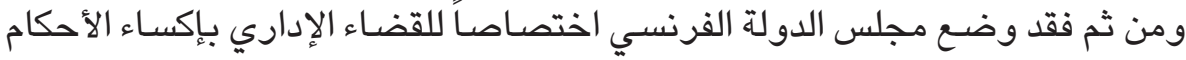

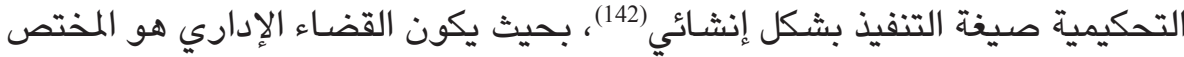

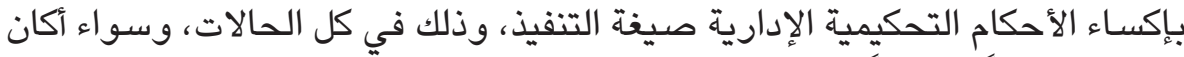

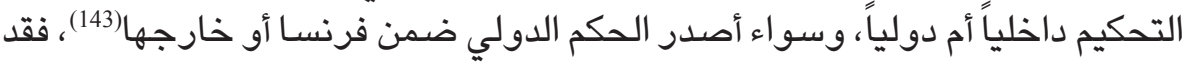

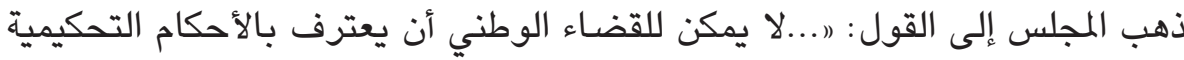

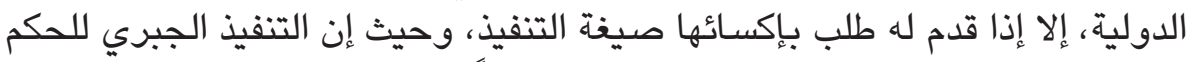

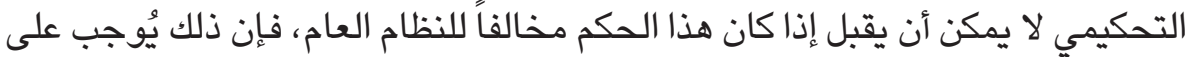

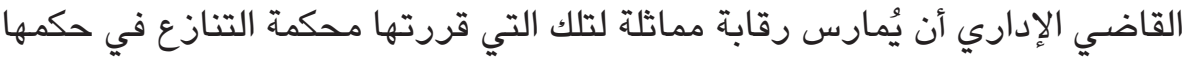

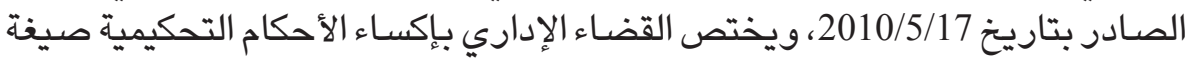

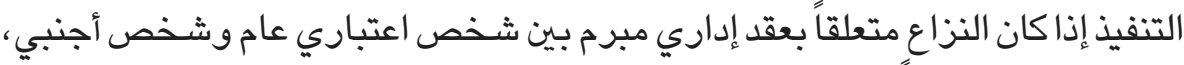

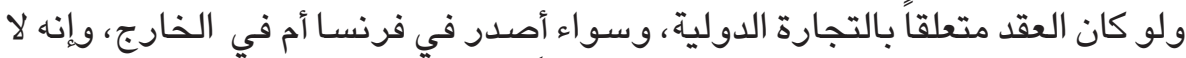
يجوز إعطاء هذه الصيفة طالما كان الحكم مخالفاً للنظام العام" (144).

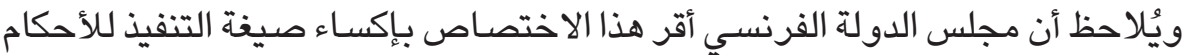

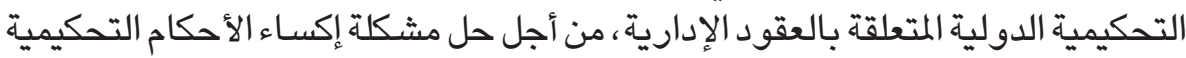

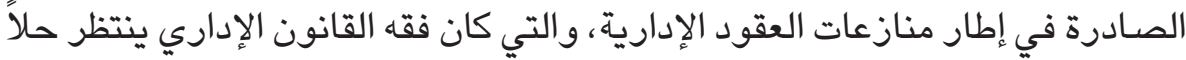

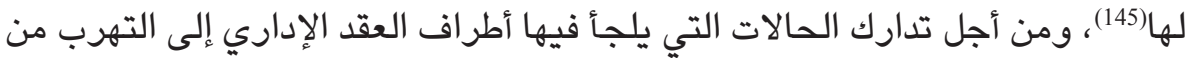

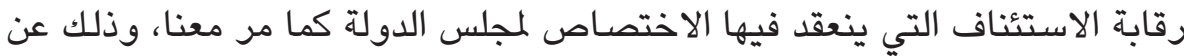

(140) Muscat H., op. cit., p.2245.

(141) Delaunay B., op. cit., p.113.

(142) Rouault D., op. cit., $\mathrm{n}^{\circ} 3$.

(143) Odinet G. et Roussel S., op. cit., p.985.

(144) C.E, Ass, 9-11-2016, Société Fosmax, Précité.

(145) لقد لاحظ الأستاذ براكونيي Braconnier منذ زمن أن مشكلة إكساء الصيغة التنفيذية للأحكام

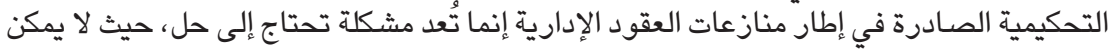

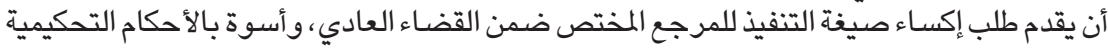

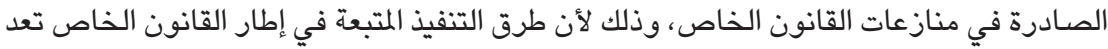

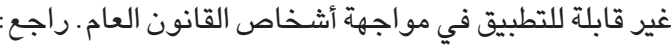

Braconnier S., Précis du droit des marchés publics, op. cit., p.450. 


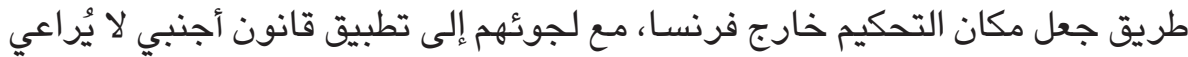

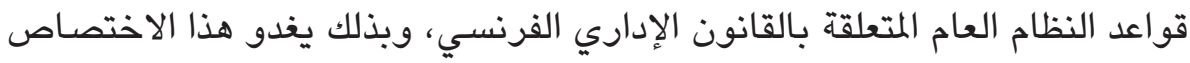
بمنزلة المصفاة التي تصفي الأحكام التي لم تخضـع لرقابة الاستئناف (146).

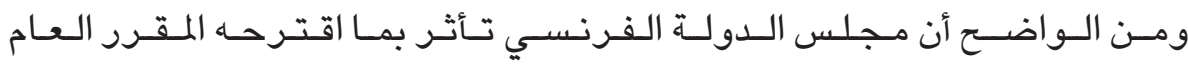

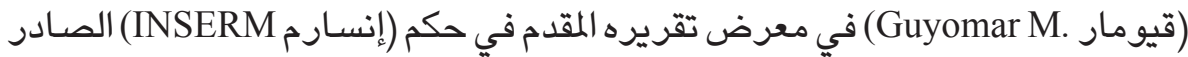

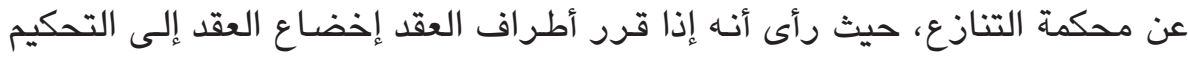

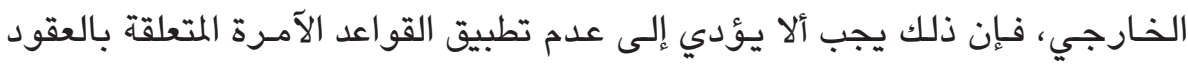

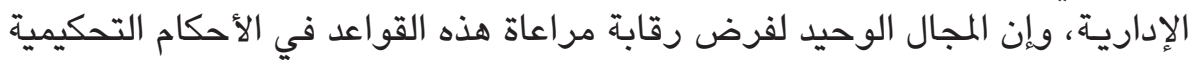

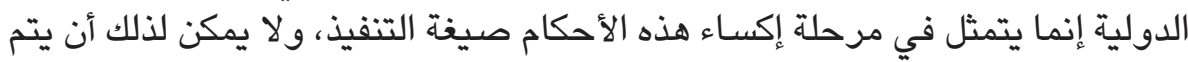

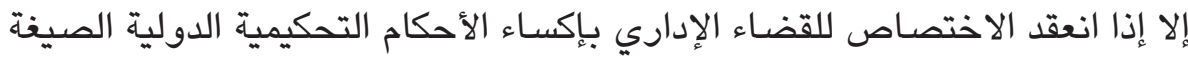
التنفيذية، واستند المقرر في ذلك إلى قياس صيغة التنفيذ على تصديق عقود الصاء الصلح L'homologation des transactions الإداري(147)، وهو الأمر الذي تم تكريسه ضمن اجتهاد مجلس الدولة الفرنسي (148). لذلك فقد استنتج جانب من الفقه الفرنسي أن القاضي الإداري في معرض إكسائه

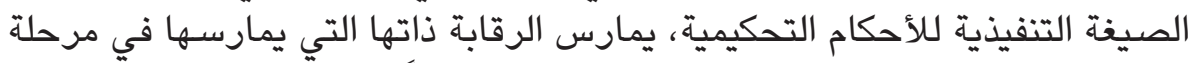

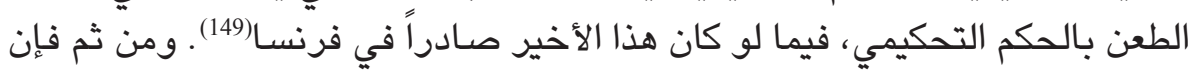

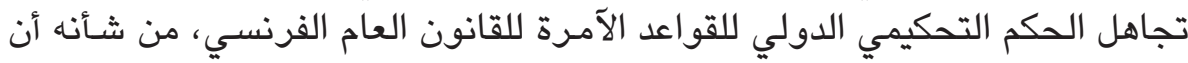

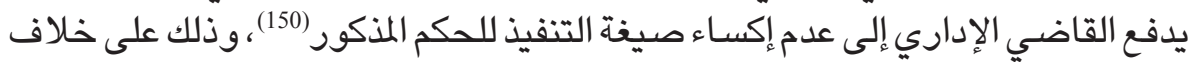

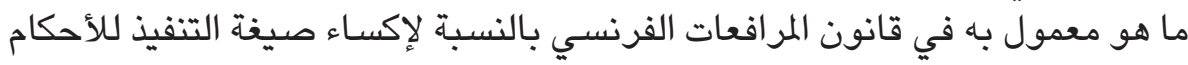

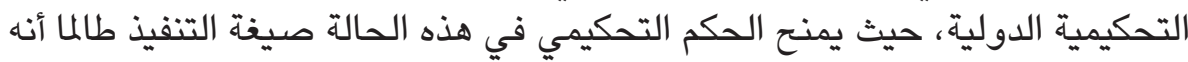

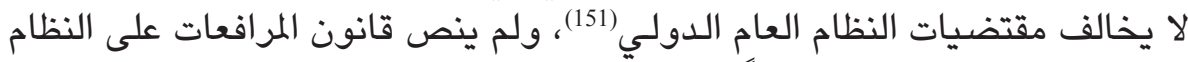

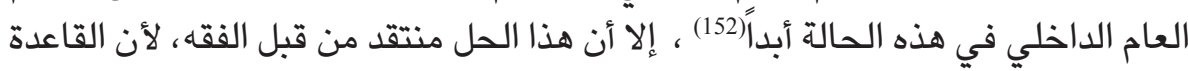

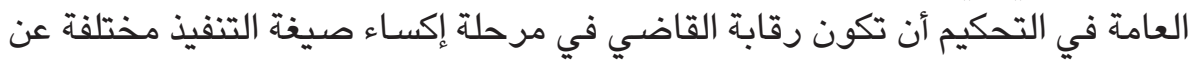

(146) Rouault D., op. cit., n³.

(147) Goyomar M., op. cit., p.971.

(148) C. E, Ass, 6-12-2002, Syndicat intercommunal des établissements du second cycle du second degré de la Haye-les Roses, R. p.433.

(149) Odinet G. et Roussel S., op. cit., p.985. Delaunay B., op.cit, p.113.

(150) Muscat H., op. cit., p.2245. Rouault D., op. cit., n³.

(151) Muscat H., op. cit., p.2245.

(152) Ibid, p.2245. 


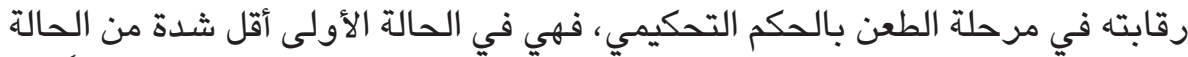

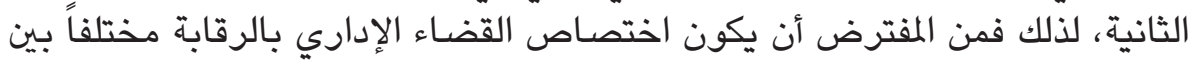

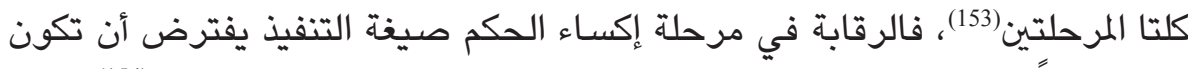

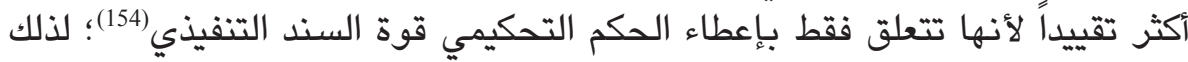

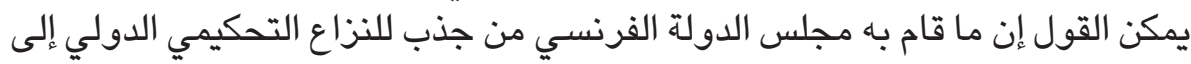

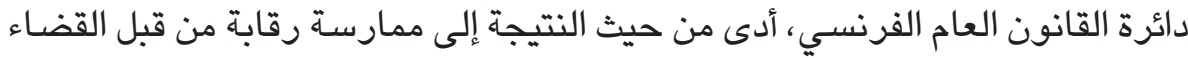

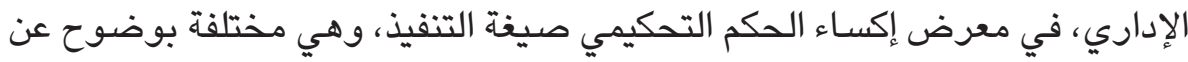

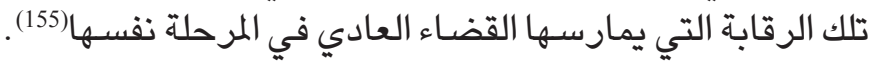

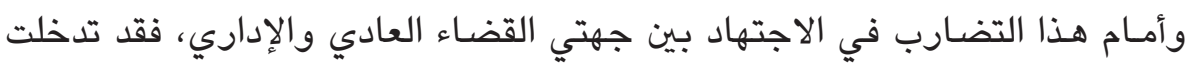

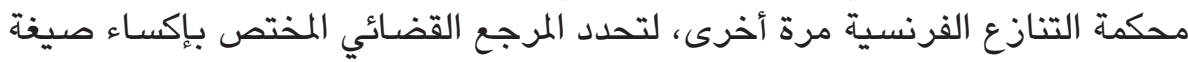

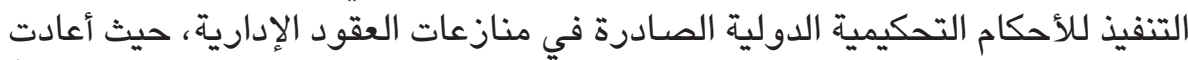

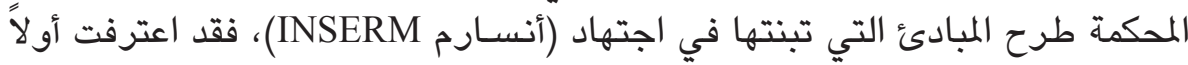

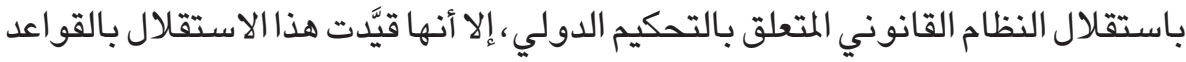

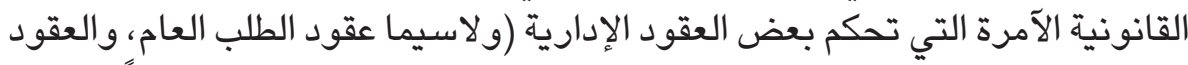

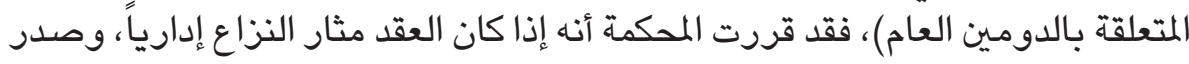

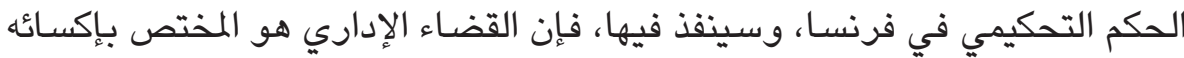

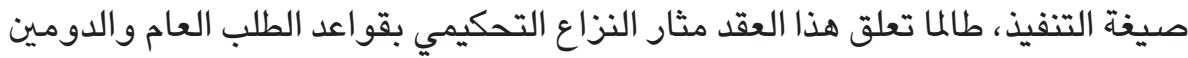

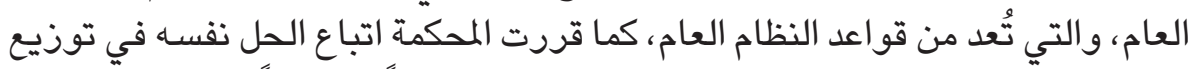

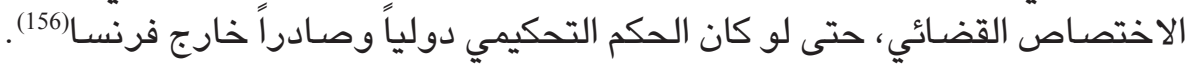

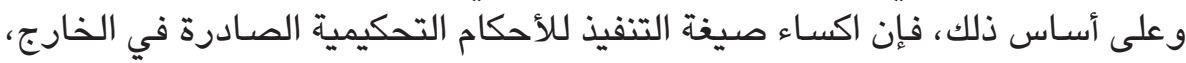

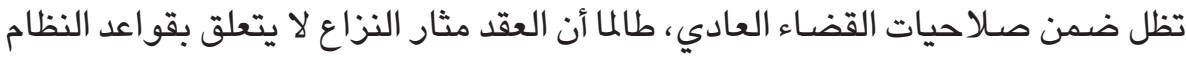

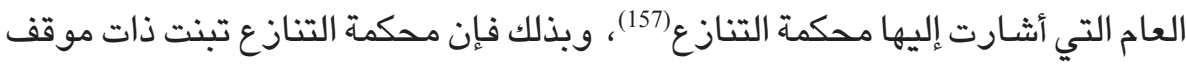
مجلس الدولة بهذا الخصوص، ومدارت التهات الازدواج القضائي إلى مرحلة إكساء الأحكام

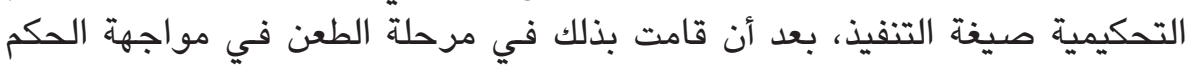

(153) Delaunay B., op. cit., p.114.

(154) Rouault D., op. cit., n³.

(155) Muscat H., op. cit., p.2245.

(156) T.C, 24-4-2017, Syndicat mixte des aéroports de Charente, Société limited marketing services limited, A.J.D.A, 2017, p.840. http://www.tribunal-conflits.fr/. N 4075.

(157) Montecler M.CH, Exequatur des sentences arbitrales internationales: le Tribunal des conflits tranche, AJDA, Paris, 2017, p.839. 
التحكيمي عند إصدار ها لحكم (أنسـارم)(INSERM) (158). وقد صرحت محكمة التنازع الفرنسية في متن حكمها الجديد هذا، أنها سـارت في منطق حكم (أنسـارم INSERM) نفسـه الصـادر بتاريخ 2010/5/17، حيث أسست هذا الحكم المتعلق باختصـاص القضـاء الإداري بإكسـاء صيغة التنفيذ لجميع الأحكام التحكيمية

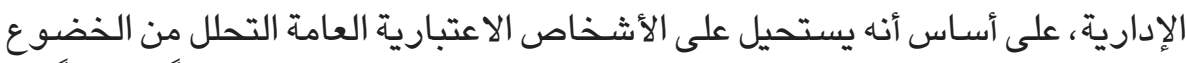
للقواعد الآمرة المتعلقة بالقانون الإداري، ولو كان الحكم التحكيمي دولياً صـادراً في

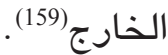

وقد لاحظ بعض الفقه الفرنسي أن هذا الحكم يثير أكثر من إشكال، فمن جهة لا يوجد إنداء نظام إجرائي خـاص بإكساء الأحكام التحكيمية الدولية صيغة التنفيذ أمـام القضـاء الإداري، على غرار هذا الذي يطبقه القضـاء العادي، استتاداً إلى القواعد المتعلقة بذلك، المقننة في قانون المرافعات الفرنسي، لذلك ينتظر من القضـاء الإداري أن يوجد أنظمة إجرائية خاصـة بذلك بشكل إنشـائي، بالنظر إلى القدرة الانشـائية التي يتمتع بها القضاء

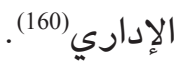

ومن جهة أخرى لابد من التساؤل إذا كان اجتهاد محكمة التتازع الجديد مخالفاً من حيث النتيجة لاتفاقية نيويورك، ولاسيما المادة (3) منها، التي تحظر أن يفرض على أحكام

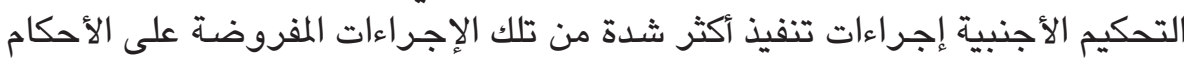
التحكيمية الصـادرة ضمن إقليم الدولة، وكذلك المادة (5) من الاتفاقية التي تحدد بشكل

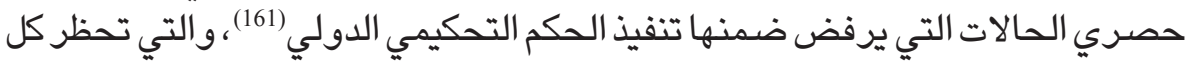
تعديل في موضوع الحكم، إلا أنه يُرد على ذلك، بأن المادة (5) من الاتفاقية نفسهـا تنص بوضوح أيضاً على أنه يمكن رفض تنفيذ الحكم التحكيمي عندما لا يكون النزاع قابِلاً للتحكيم، وعندما يكون مخالفاً للنظام العام في الدولة التي يطلب التنفيذ على إقليمها، مما لا يحول دون قيام القاضي الإداري الفرنسي برقابة قابلية النزاع للتحكيم، واحترام

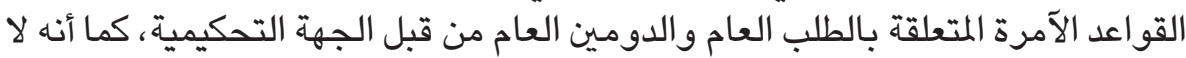
يُوجد أي تمييز إجرائي بشـأن إكساء صيفة التنفيذ بين أحكام تحكيمية داخلية وأحكام تحكيمية خارجية، طالما أن المرجع المختص بإكساء صيغة التنفيذ للأحكام التحكيمية

(158) Montecler M.CH, Exequatur des sentences arbitrales internationales: le Tribunal des conflits tranche, AJDA, Paris, 2017, p.839.

(159) Odinet G. et Roussel S., op. cit., p.986.

(160) Ibid, p.986. Weiller L., op. cit., comm. 162.

(161) Weiller L., op. cit., comm. 162. 
واحد، متى كان هذا الحكم متصلاً بنزاع عقدي يُثير مسائل النظام العام لبعض العقود الإدارية (وهي العقود الإدارية الكبرى) (162).

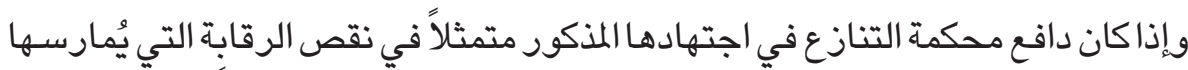

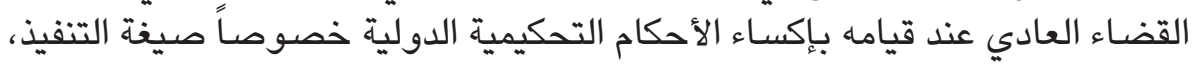

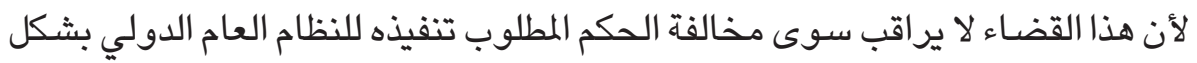

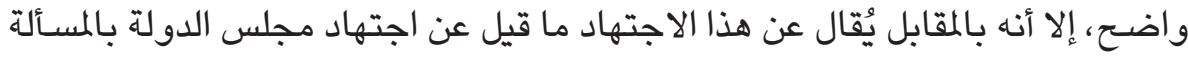

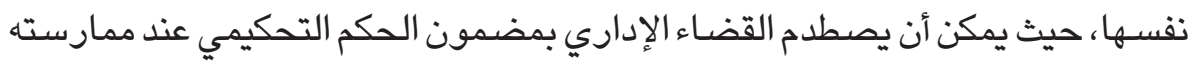

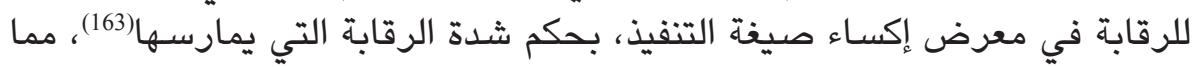

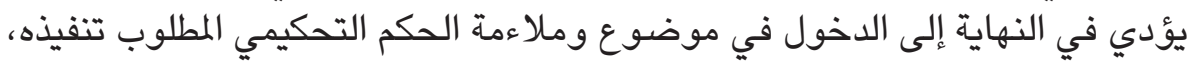

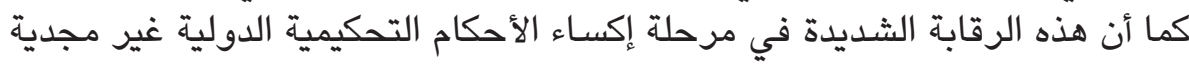

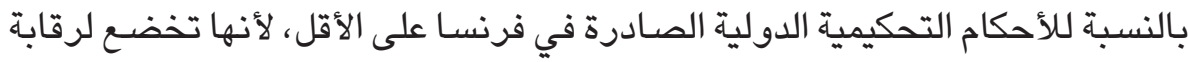

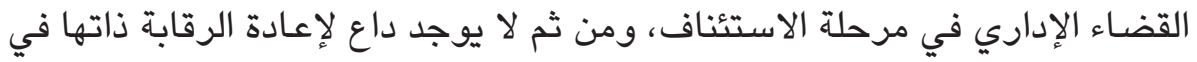
مرحلة إكساء صيغة التنفيذ(164).

لذلك فقد ذهب البعض إلى القول إن ما ذهبت إليه محكمة التنازع من توزيع الصلاحية

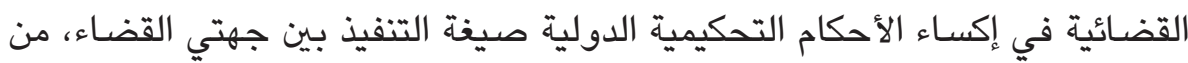

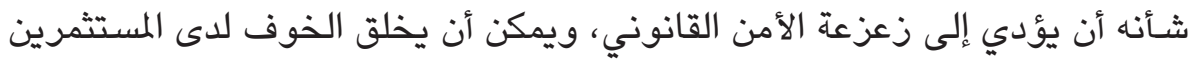

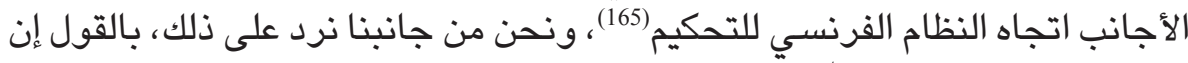

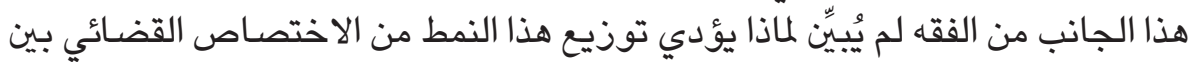

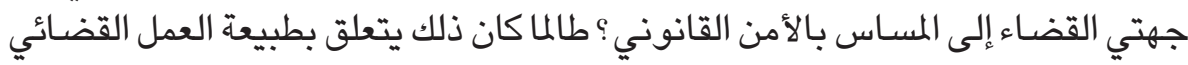

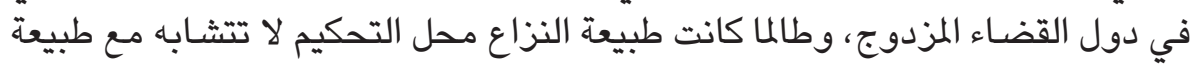

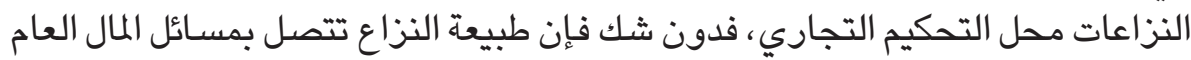

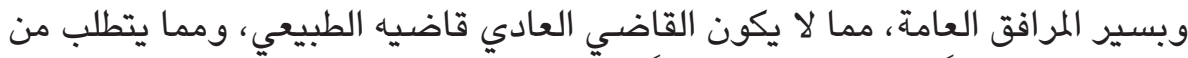

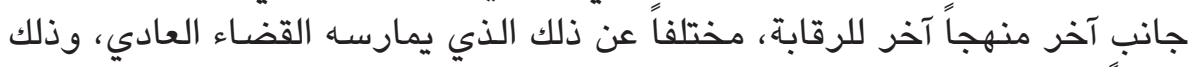

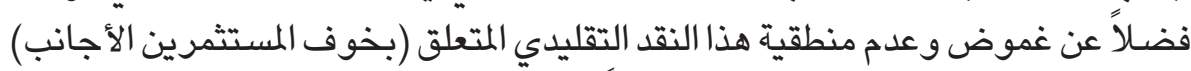

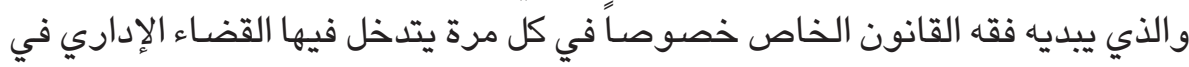
مسـائل التحكيم. بلده.

(162) Odinet G. et Roussel S., op. cit., p.986.

(163) Weiller L., op. cit., comm. 162.

(164) Rouault D., op. cit., $n^{\circ} 3$.

(165) Weiller L., op. cit., comm. 162. 


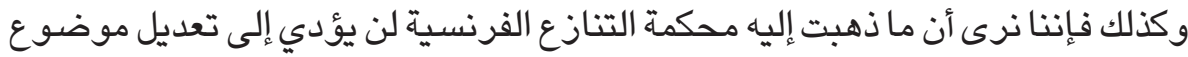

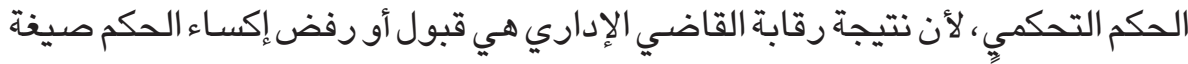

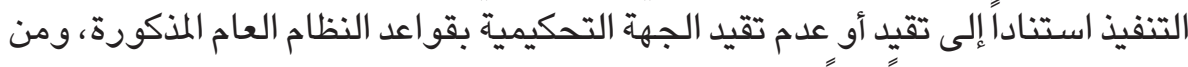

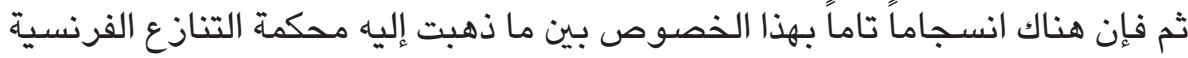
من جهة، و واتفاقية نيويورك من جهة أخرى .

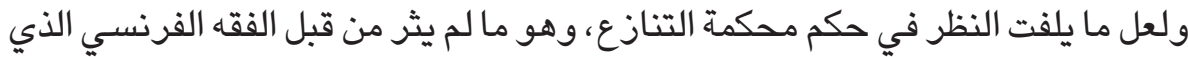

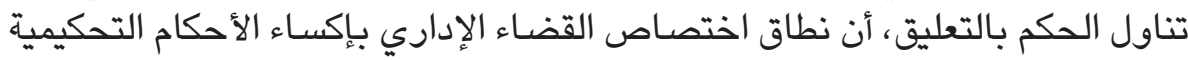

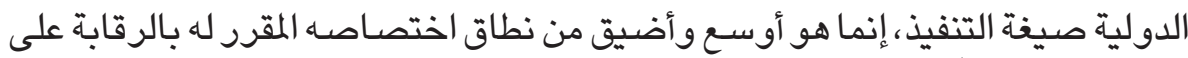

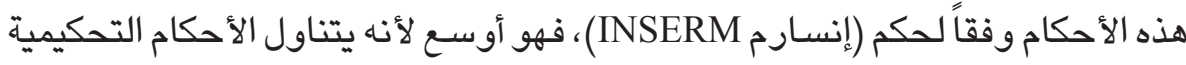

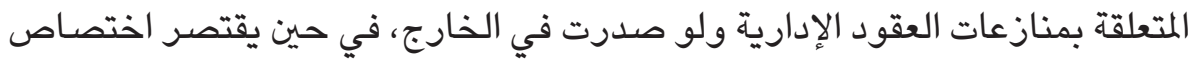

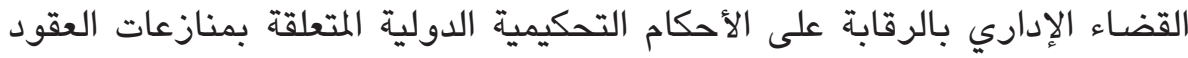

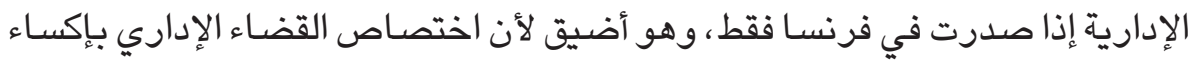

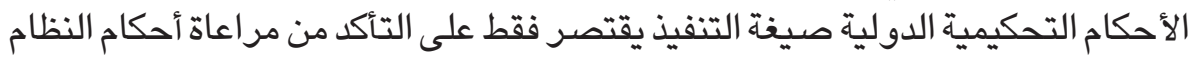
العام دون التطرق إلى موضوع ع الحكم التحكيمي.

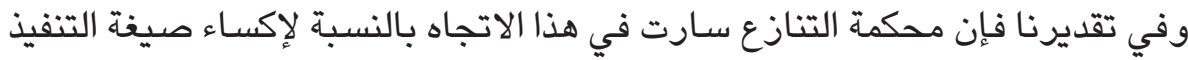

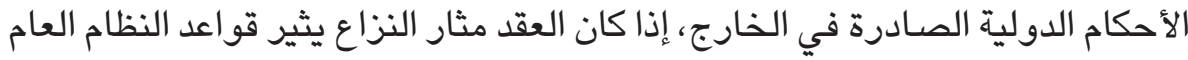

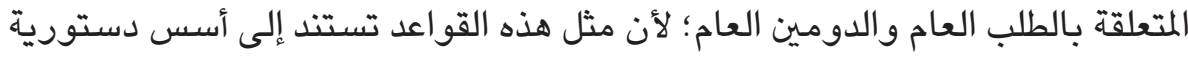

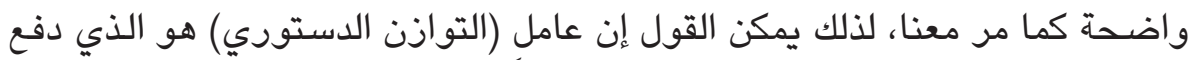
محكمة التنازع الفرنسية إلى تبني هذا الحل حديثاً.

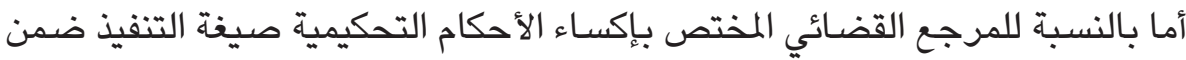

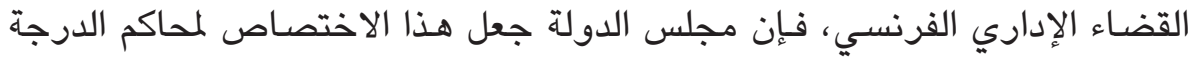

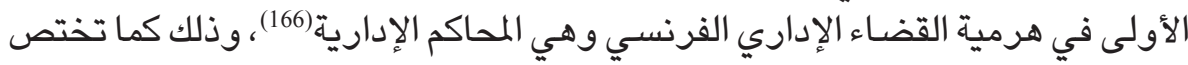

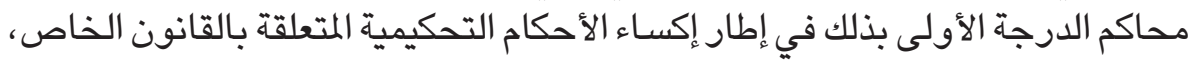

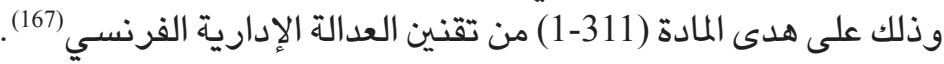

(166) C.E, Ass, 9-11-2016, Société Fosmax, Précité.

(167) Weiller L., op. cit, comm. 162. Rouault.D, op.cit, n³. Muscat H, op. cit., p.2245. 


\section{الخاتمة}

نستنتج من خلال ما عرضناه في هذا البحث أن هناك اختلافاً واضحاً بين النظام القانوني

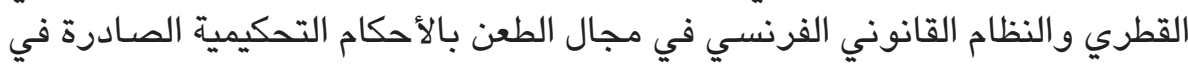

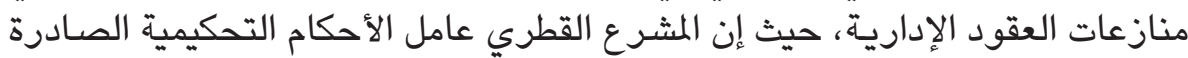

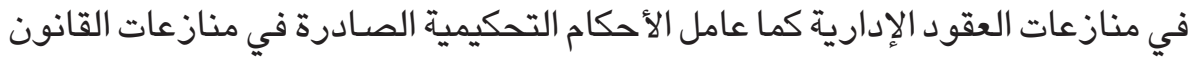

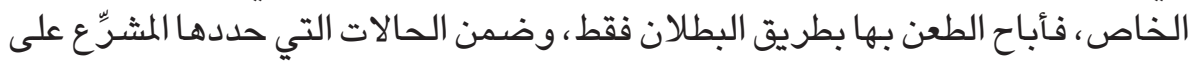
سبيل الحصر.

وقد أسند المشرِّع القطري الاختصاص بدعوى البطلان إلى دائرة منازعات التحكيم الإني

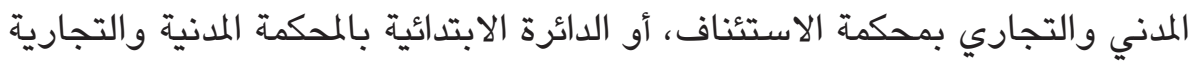

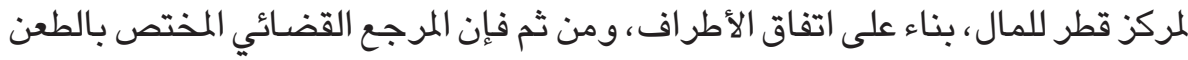

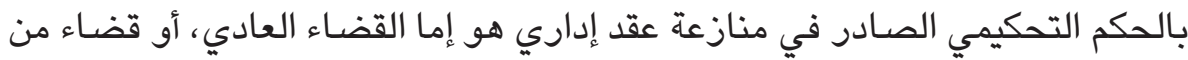

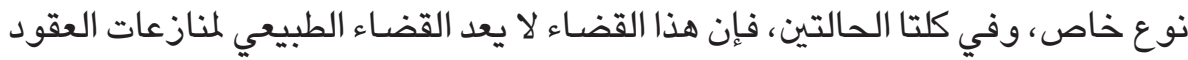

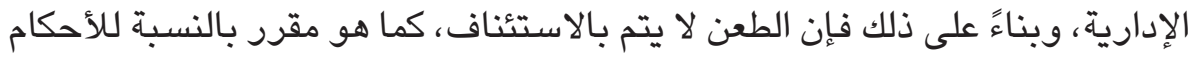

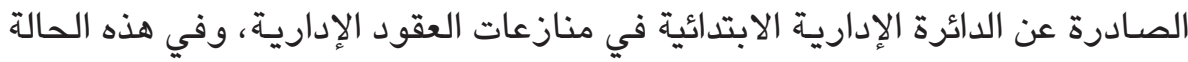

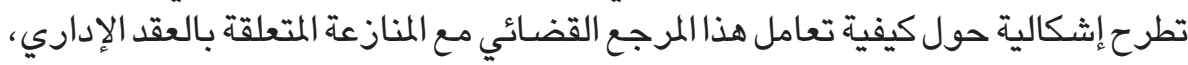
وما هو النظام القانوني الذي سيطبقه في هذه الحالة على هذه المنازعة.

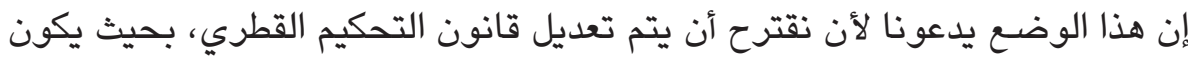

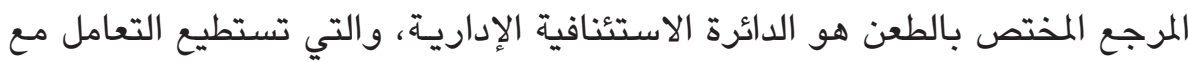

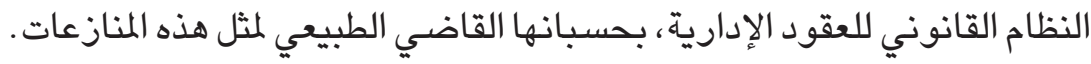

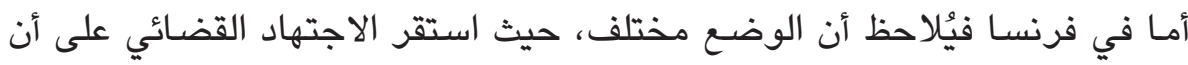

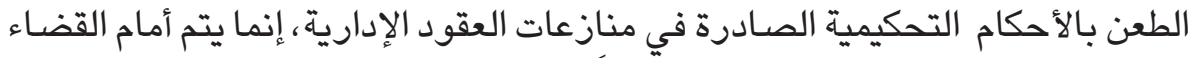

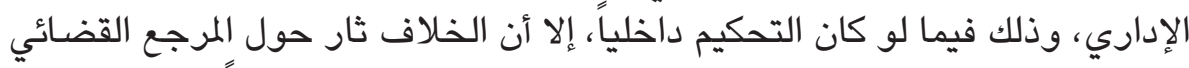

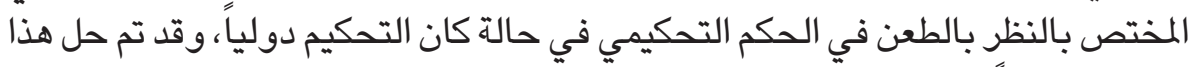

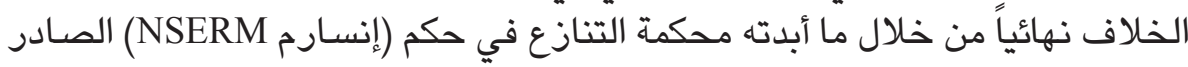

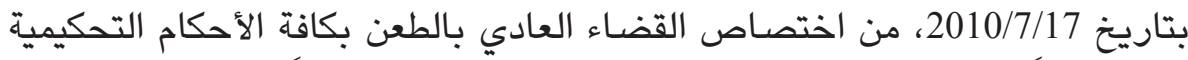

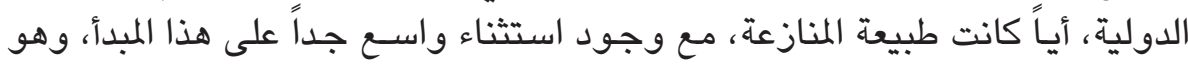

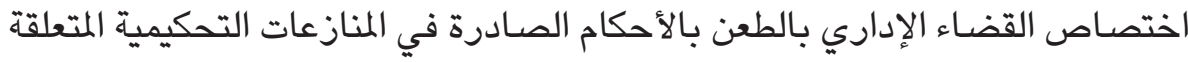

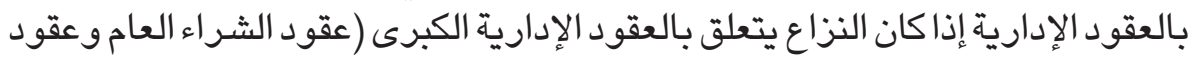

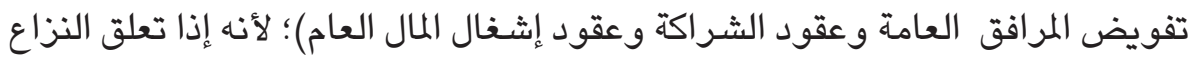


بأحد هذه العقود، فإن الأمر يتطلب عندئذ تطبيق القواعد المتعلقة بالعقود الإدارية، والتي

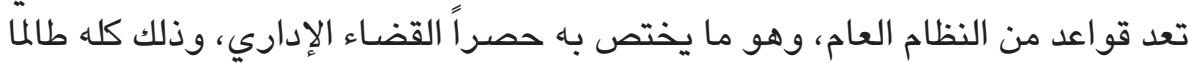

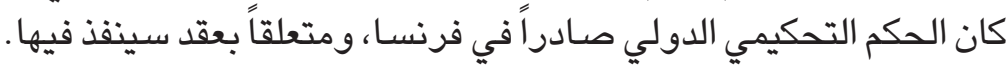
وقد ذهب مجلس الدولة الفرنسي، وعلى خلاف ما ذهب إليه قانون المرافعات المدنية

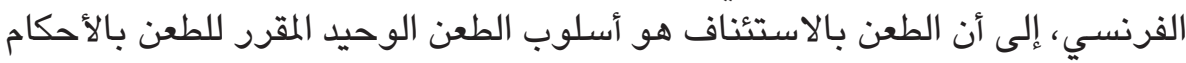

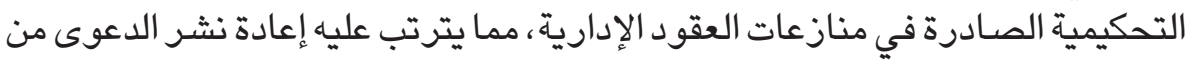

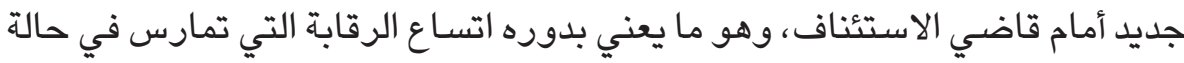

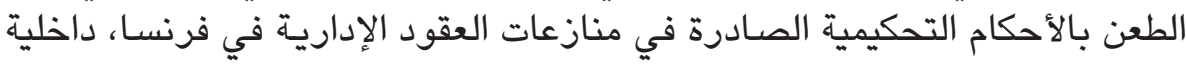
كانت أم دولية.

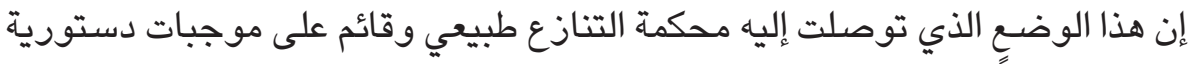

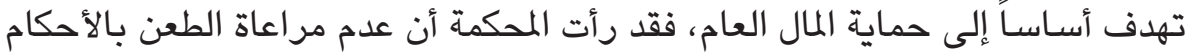

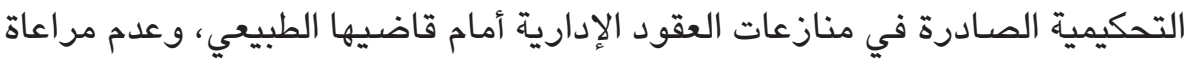

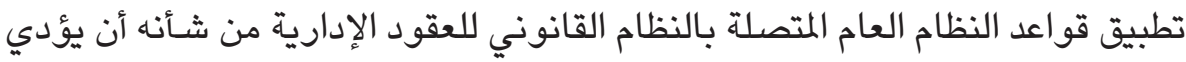

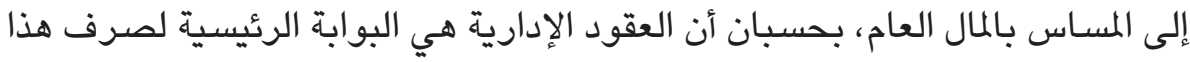
المال والطريقة القانونية للتعامل به.

وينعقد الاختصاص بالنظر في الطعن بالحكم التحكيمي المتعلق بمنازعة عقد إداري

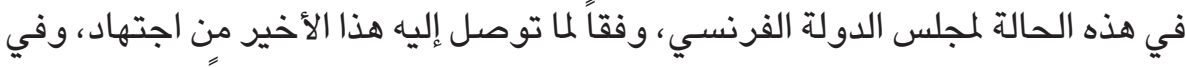

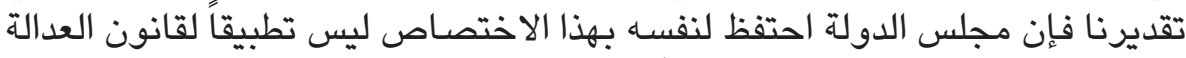

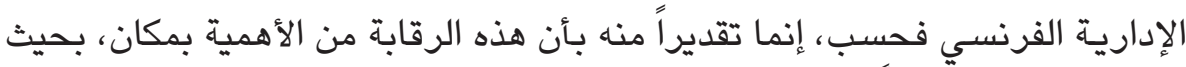

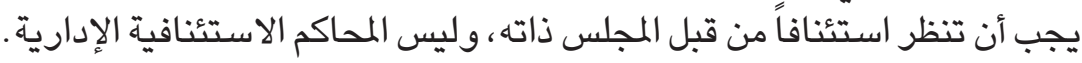
ونتيجة المقاربة بين الوضع القانوني في كل من قطر وفرنسا، بشأن الطعن بالأحكام

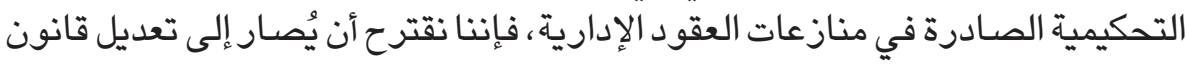

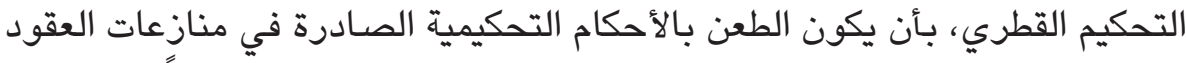

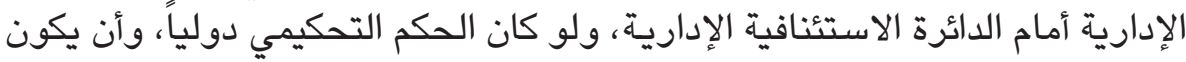

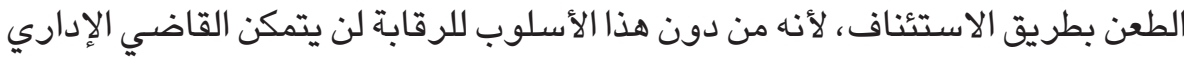

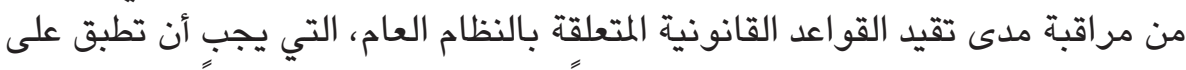

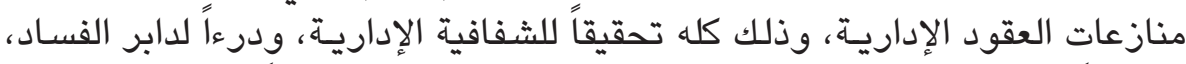

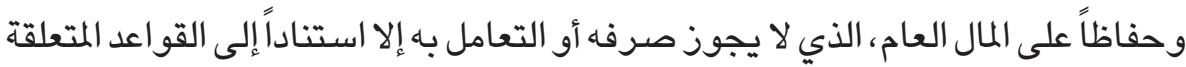
بذلك والتي هي من النظام العام، والمقررة بموجب النظام هوره النظام القانوني الداخلي. 


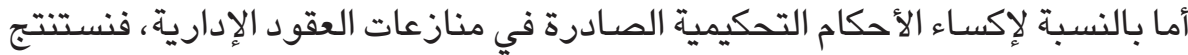

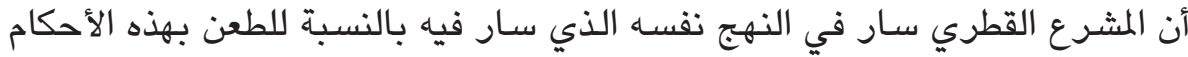

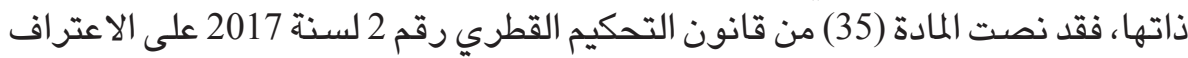

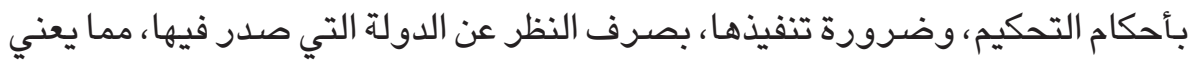

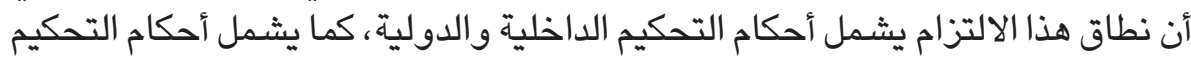
بغض النظر عن طبيعة المنازعة التي صدر بشام أحسأنها حكم التحكيم.

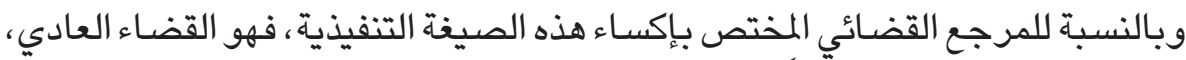

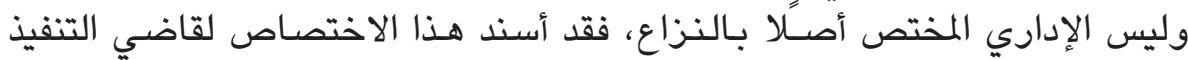

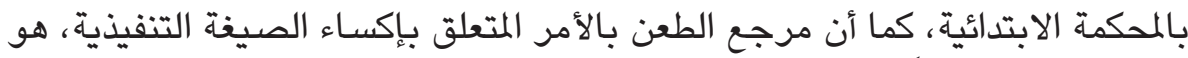

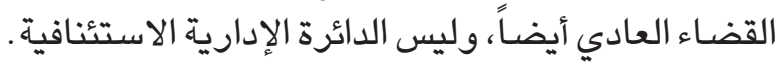

وقد حددت المادة (35) من قانون التحكيم الحالات التي يجوز معها رفض إكساء صيغة

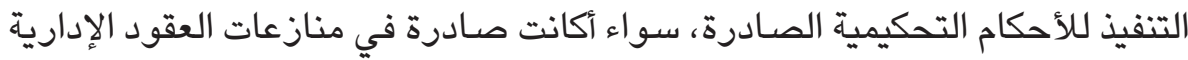

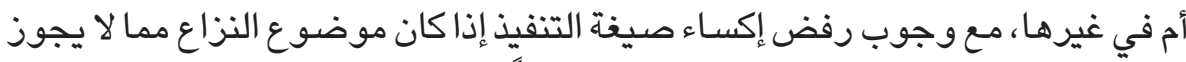

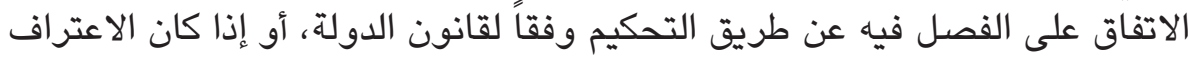

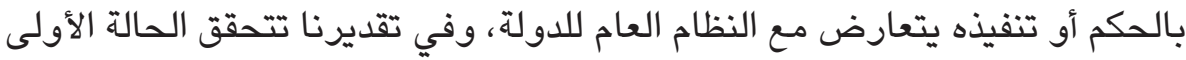

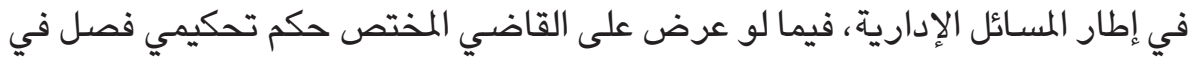

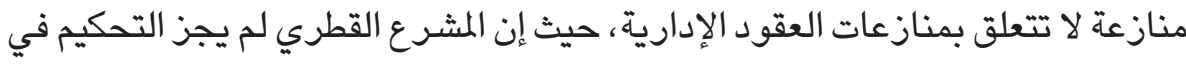

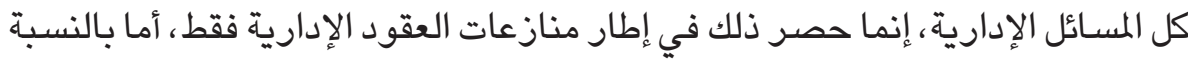

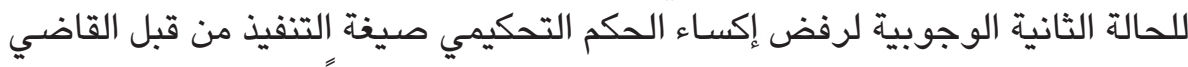

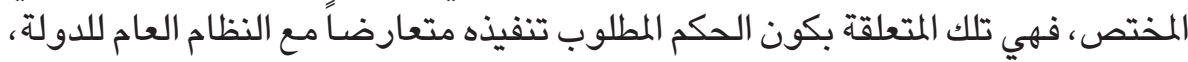

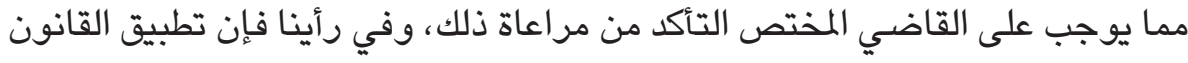

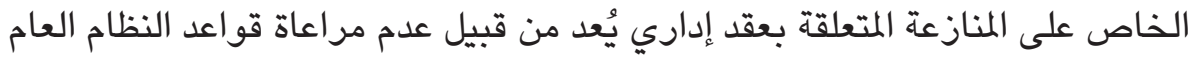

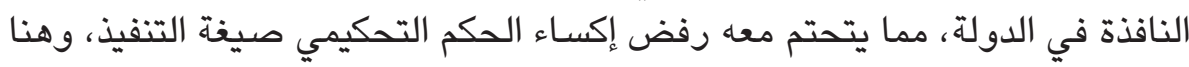
نقترح أن يتبنى المشرع القطري ذلكالك صدراحة.

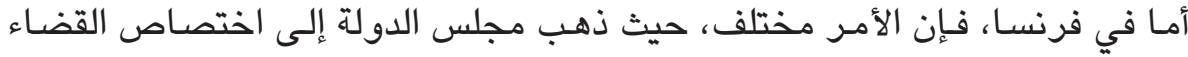

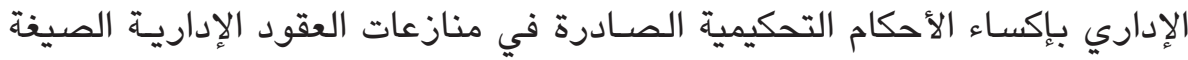

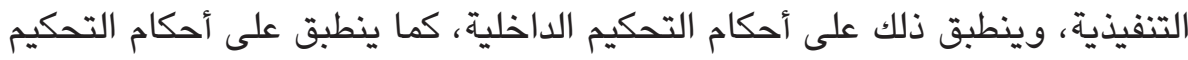

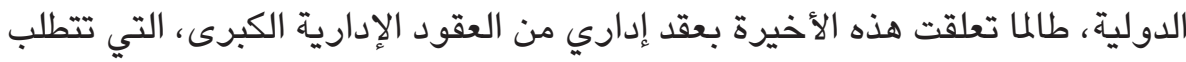

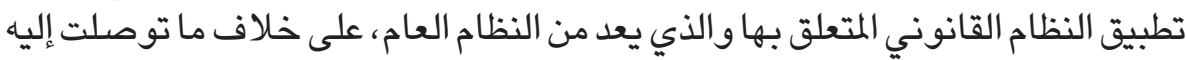

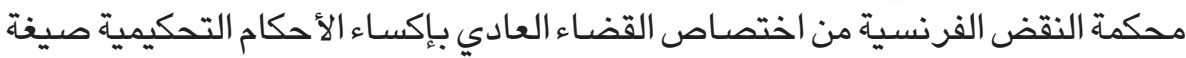




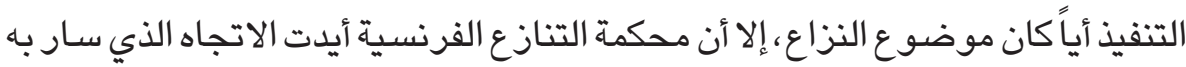

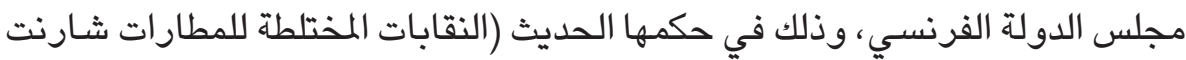

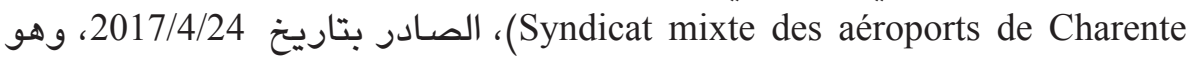

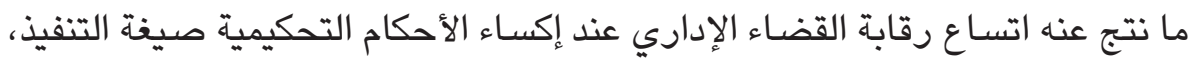

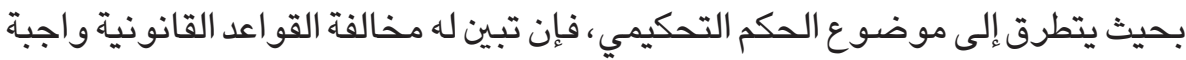

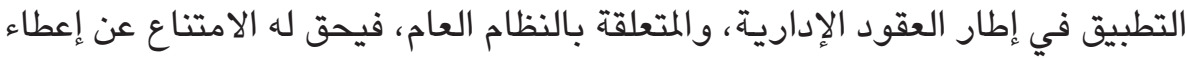

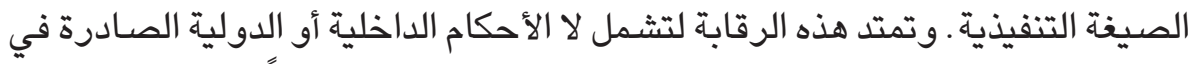

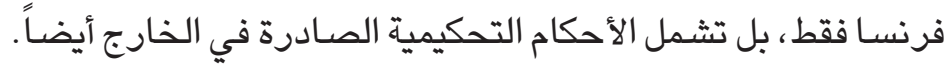
وإن ما دفع مجلس الدولة الفرنسي ومحكمة التنازع إلى تبني هذا الاتجاه هو الرغبة في الإني

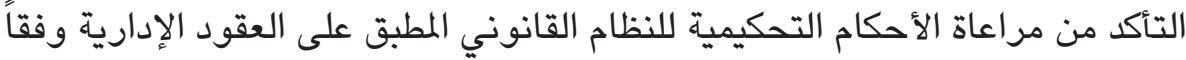

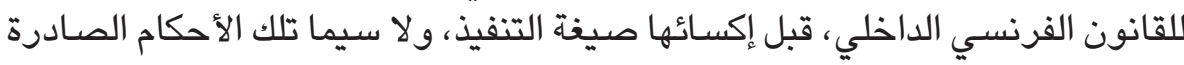

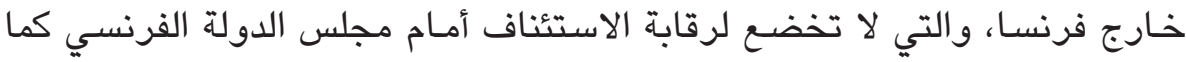
رأينا.

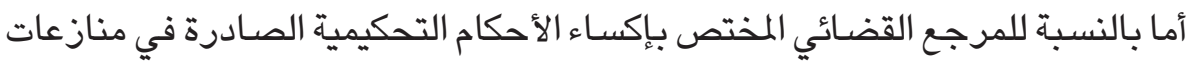

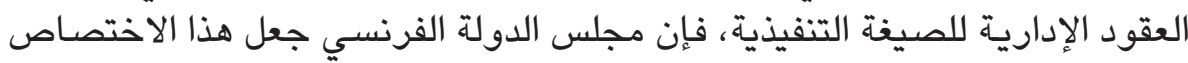

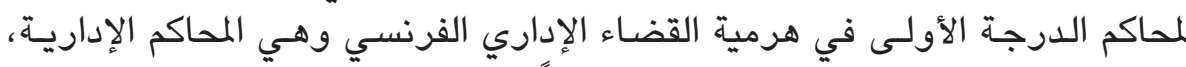

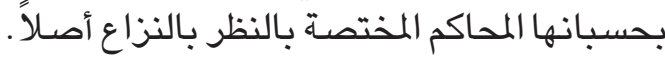

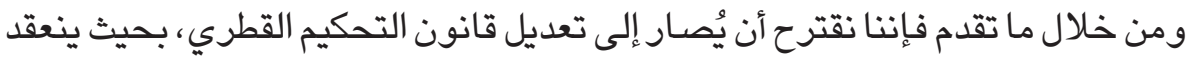

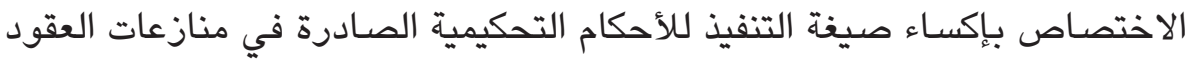

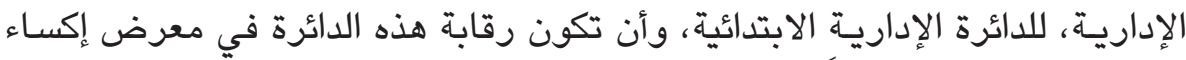

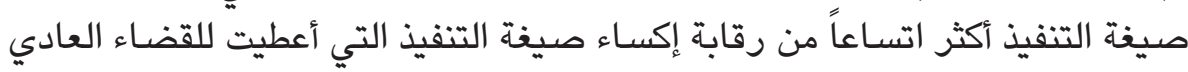
بموجب النصوص الحالية. 


\section{المراجع \\ أولاًِ- باللغة العربية}

- أحمد السيد صاوي، الوسيط في شرح قانون المرافعات المدنية والتجارية، بلا دار

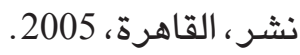

- - مهند نوح، الإيجاب والقبول في العقد الإداري، منشورات الحلبي الحقوقية، بيروت،

- - علي مصطفى الشيخ ، التحكيم على درجتين، مجلة البحوث القانونية والاقتصادية،

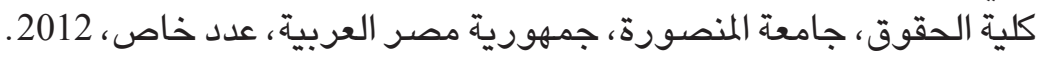
- عماد قميناسي : - ع

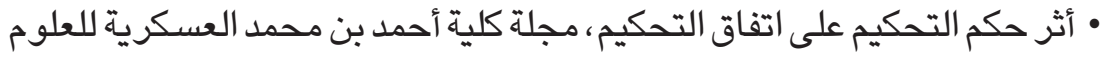
الإدارية والقانونية، الدوحة، قطر ، المجلد الثمات الثاني، العدد الثاني، 2017. • تنفيذ حكم التحكيم، المؤسسة الحديثة للكتاب، بيروت، 2018. - فتحي والـي، قـانـون التحكيم في النظريـة والتطبيق، منشـأة المـــارف،

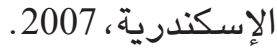

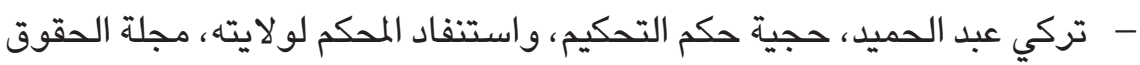

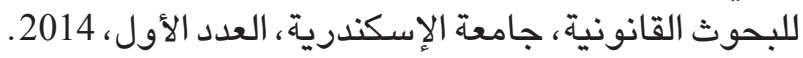

\section{ثانياً- باللغتة الفرنسية}

- Benoit F.P., Le Droit Administratif Français, Dalloz, Paris, 1968.

- Braconnier S., Précis du Droit des Marchés publics, Le Moniteur, Paris, 2007.

- Chapus R., Droit du Contentieux Administratif, 12ed., Montchrestien, Paris, 2006.

- Conseil d'Etat: Régler Autrement les Conflits, Les Etudes du Conseil d'Etat, Paris, 1993. 
- De Laubadère A et Delvolvé P. et Moderne F., Traité des Contrats Administratifs, T2, L.J.D.G, Paris, 1984.

- Delaunay B., Les Sentences Arbitrales Concernant les Personnes Publiques en Matière de Commerce International: le Contrôle du Juge Administratif, RFDA, Paris, 2017.

- Delvolvé P., Le Contentieux des Sentences Arbitrales National de la Recherche Médicale, R.F.D.A, Paris, 2010.

- Gaillard E., Le Nouveau Droit Français de L'Arbitrage Interne et International, D, Paris, 2011.

- Guettier Ch., Droit des Contrats Administratifs, P.U.F, Paris, 2011.

- Lichére F., Droit des Contrats, Dalloz, Paris, 2014.

- Liu. O, L'Exécution des Sentences Arbitrales Etrangers: Etude comparative entre la France et la Chine, Thèse, université Paris II, Panthéon - Assas, Paris, 2016.

- Lombard F., Arbitrage et Droit Administratif, R.T.D.C, Paris, 2017.

- Loquin E.,

- De la Dualité de L'Arbitrage Commercial et L'Arbitrage Administratif, R.T.D.C, Paris, 2010.

- La Réforme du Droit Français Interne et International de L'Arbitrage, RTD Com, Paris, 2011.

- L'Exequatur de La Sentence International ayant pour objet un litige portant sur un contrat administratif international est de la compétence du juge judiciaire, Impossible accord entre la cour de cassation et le conseil d'Etat, R.T.D.C, 2016.

- Lumaire S., Arbitrage International et Droit Public: le Tribunal des Conflits déçoit, D, Paris, 2010. 
- Montecler. M.CH, Exequatur des Sentences Arbitrales Internationales: le Tribunal des Conflits Tranche, AJDA, Paris, 2017.

- Muscat H., Les Recours devant La Juridiction Administrative en Matière de Sentences Arbitrales Internationales, La Semaine Juridique Administrations et Collectivités territoriales $n^{\circ}$ 31-35, 29 Juillet 2013.

- Najib M. M., L'Intervention du Juge dans La Procédure Arbitrale, Thèse, Université de Bordeaux, France, 2016,

- Odent R., Contentieux administratif, Dalloz, Paris, T1, 2007.

- Odinet G. et Roussel S., La jurisprudence INSERM, embrasse l'exequatur, A.J.D.A, Paris, 2017.

- Richer L., Droit des Contrats Administratifs, L.G.D.J, Paris, 2014.

- Rouault D., Arbitrage et Contrats Publics Internationaux, Journal de l’arbitrage, L’Université de Versailles, France, n 1, Octobre 2014.

- Yolka PH., Traité de Droit administratif, Les Modes Alternatifs de Règlement des Litiges Administratifs, T2, Dalloz, Paris, 2011.

- Weiller L., L'Exequatur des Sentences Arbitrales Internationales, Procédures $n^{\circ} 7$, Juillet 2017. 
المحتوى

\begin{tabular}{|c|c|}
\hline الصفحة & الموضوع \\
\hline 237 & الملخص \\
\hline 239 & المقدمة \\
\hline 242 & المبحث الأول في منازعات العقل القضـاء الرسمي في إلطارية الطعن بالحكم التحكيمي \\
\hline 242 & 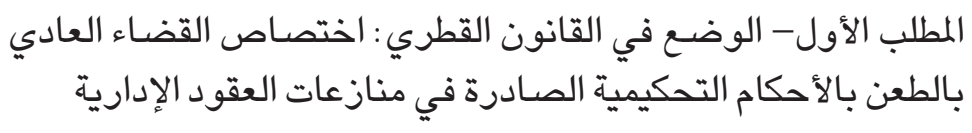 \\
\hline 245 & 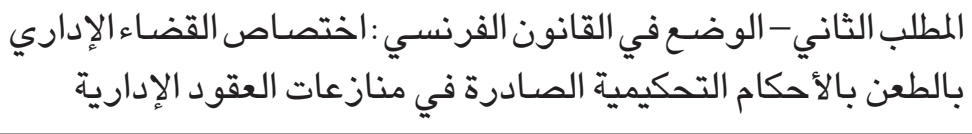 \\
\hline 258 & المبحثة الثاني - تدخل القضـاء الرسمي في نطاق إكسـاء الحكم التحكيمي \\
\hline 258 & 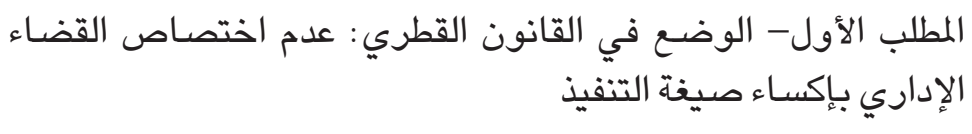 \\
\hline 262 & 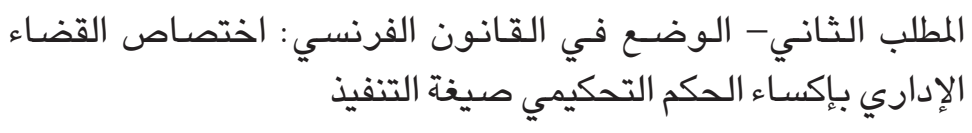 \\
\hline 274 & الخاتمة \\
\hline 278 & المراجع \\
\hline
\end{tabular}


